\title{
O SONHADO E O SOFRIDO:
}

\section{A cidade como catalisador dos sonhos da modernidade}

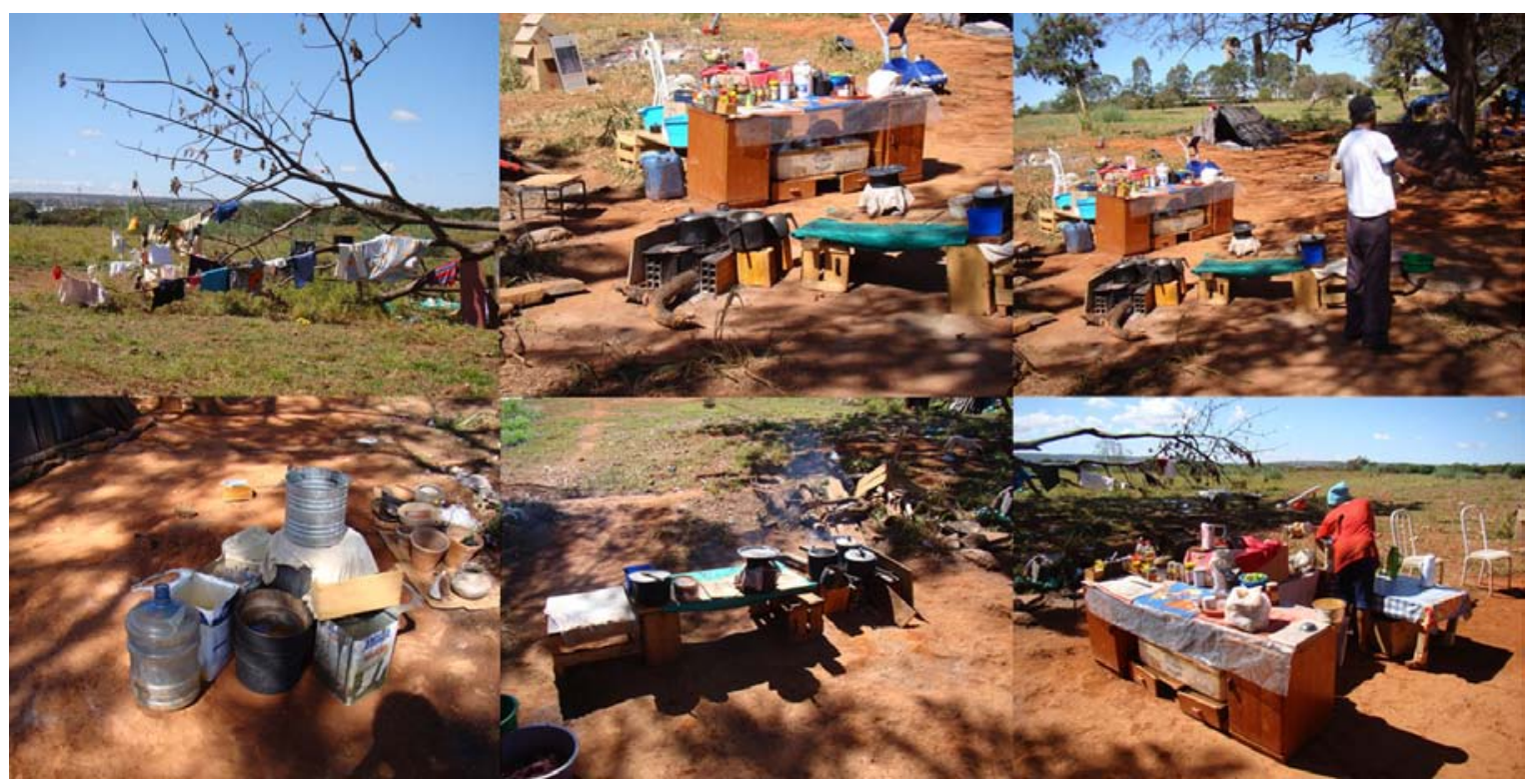

Marília Serena Porto Sotero

Brasília 


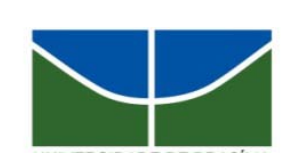

\author{
UNIVERSIDADE DE BRASÍLIA \\ Instituto de Ciências Humanas \\ Departamento de Geografia
}

Marília Serena Porto Sotero

\title{
O SONHADO E O SOFRIDO:
}

A cidade como catalisador dos sonhos da modernidade uma reflexão sobre a produção espacial pela população de rua do Distrito Federal.

Monografia apresentada ao Departamento de Geografia da Universidade de Brasília - UnB como exigência final para a obtenção do título de Bacharel em geografia.

Orientadora: Profa. Dra Marília Luíza Peluso 
2009 
UNIVERSIDADE DE BRASÍLIA

Instituto de Ciências Humanas

Departamento de Geografia

\title{
O sonhado e o sofrido: a cidade como catalisador dos sonhos da modernidade
}

\author{
Marília Serena Porto Sotero
}

Monografia apresentada ao Departamento de Geografia da Universidade de Brasília - UnB como exigência final para a obtenção do título de Bacharel em geografia.

APROVADA POR:

Profa. Dra Marília Luíza Peluso, doutora em psicologia (Pontifícia Universidade Católica de São Paulo)

(Orientadora)

Camila Potyara Pereira, Socióloga (UnB) e mestre em Política Social (PPGPS/SER/IH/UnB) 
Rosângela Vieira Viana Neri, mestre em

Geografia (Universidade de Brasília) 



\section{DEDICATÓRIA}

Dedico esse trabalho a Dora Porto, minha mãe que é o meu amor, meu orgulho, minha vida. 


\section{AGRADECIMENTOS}

Agradeço a todos os professores, funcionários e colegas pelo companheirismo e amizade. Agradeço a minha orientadora Professora Dra. Marília Luiza Peluso por ter aceitado me orientar nesta importante etapa da minha formação como geógrafa. A minha louca, grande e amada família: avôs, pais, irmãos, sobrinhos, tios, madrinha, amigos e namorado pelo apoio e o amor incondicional. E, a todas as pessoas que de alguma forma me ajudaram, participando do trabalho de campo, confiando em mim e me fornecendo informações sobre suas histórias de vida e percepções do mundo. 


\section{EPÍGRAFE}

"Enquanto os homens exercem seus podres poderes. Morrer e matar de fome de raiva e de sede são tantas vezes gestos naturais..." (Caetano Veloso)

Título II Dos Direitos e Garantias Fundamentais Capítulo I Dos Direitos e Deveres Individuais e Coletivos Art. $5^{\circ}$ Todos são iguais perante a lei, sem distinção de qualquer natureza, garantindose aos brasileiros e aos estrangeiros residentes no País a inviolabilidade do direito à vida, à liberdade, à igualdade, à segurança e à propriedade. 


\section{RESUMO}

Este trabalho de pesquisa é sobre a produção espacial nas cidades e os espaços produzidos por aqueles brasileiros migrantes de áreas menos urbanizadas. Brasileiros que passam a constituir a população de rua e constroem espaços móveis, instáveis e não legítimos segundo a perspectiva do capital imobiliário. Apesar de não ser difícil constatar as dificuldades por eles enfrentadas ao se instalarem no novo ambiente, o fluxo da pobreza para as grandes cidades continua. Por quê? Este panorama paradoxal caracteriza esta monografia que pretende levantar a percepção de migrantes "voluntários" da área rural que atualmente habitam o espaço urbano, buscando investigar sua motivação para a migração, sua expectativa antes e depois do deslocamento para a cidade, tomando como base para análise sua concepção sobre o que seja cidade. Essa indagação é o que justifica o levantamento teórico e o trabalho de campo, que se equilibra entre o descortinar do sonho e o enfrentamento da realidade.

Palavras-chave: cidade. população de rua. espaço negado. espaço legitimado pelo capital imobiliário. 


\section{ABSTRACT \\ DREAMING AND SUFFERING: CITY AS A CATALYST OF MODERNITY DREAMS}

This paper studies the cities' spatial production and spaces developed by Brazilian migrant from less urbanized areas. These citizens are Brazilian who become street people and construct mobile spaces, which are instable and not legitimate according to a property capital. Although it is not hard to verify the difficulties they face while occupying the new place, poverty flowing to cities continues. And why it happens? This paradox panorama is the main point of this paper which aims to report the perception of "voluntary" migrants who came from rural places and now live at urban places. It also intend to investigate their motivation for migration, their expectations before and after the moving to city, taking into account as the basis for analysis their conception on what is a city. This question is the justification for the theoretical research and field work that is the equilibrium between dreaming and facing reality.

Keywords: city. street people. denied space. space legitimated by property capital. 


\section{LISTA DE ILUSTAÇÕES}

Figura 1 - Mapa da localização dos acampamentos

Figura 2 - Varal de roupas no acampamento localizado na Via L3 Norte .38

Figura 3 - Cozinha do acampamento localizado na Via L3 Norte. 39

Figura 4 - Área comum no acampamento localizado na Via L3 Norte. 39

Figura 5 - Mulher preparando o almoço no acampamento localizado na Via L3 Norte .40

Figura 6 - Fogão improvisado no acampamento localizado na Via L3 Norte 40

Figura 7 - Água utilizada no acampamento localizado na Via L3 Norte 41 


\section{SUMÁRIO}

INTRODUÇÃO: O TRABALHO E SEU OBJETIVO .............................................14

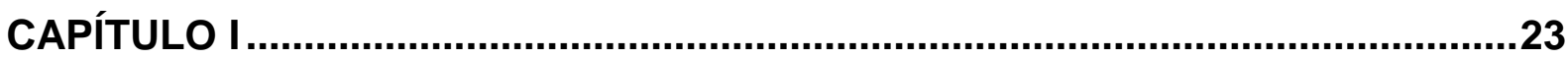

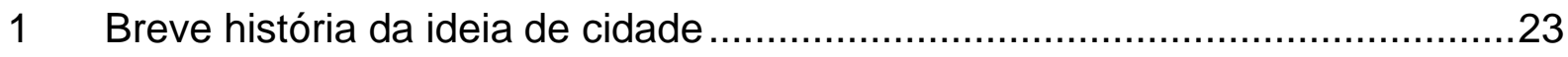

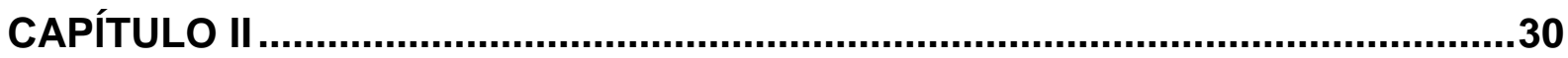

1 Marco teórico: o espaço negado na cidade …..............................................30

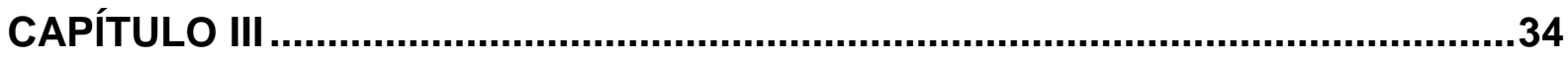

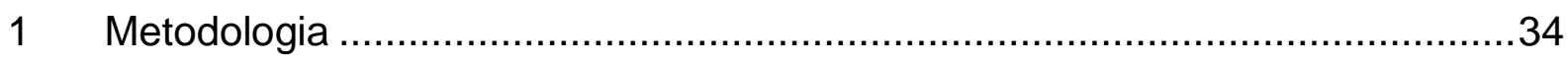

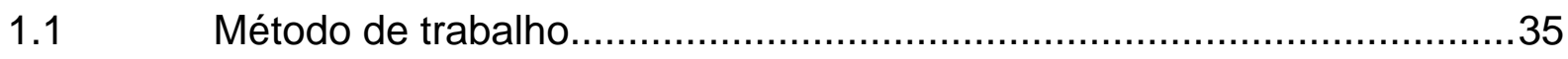

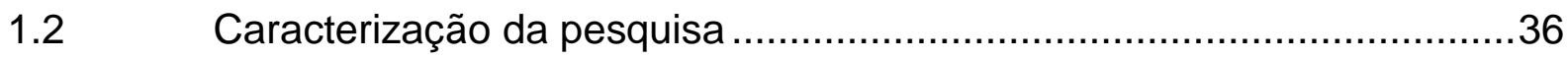

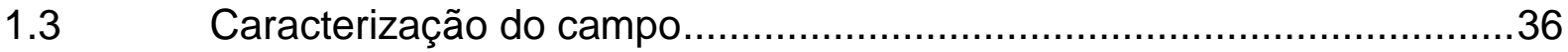

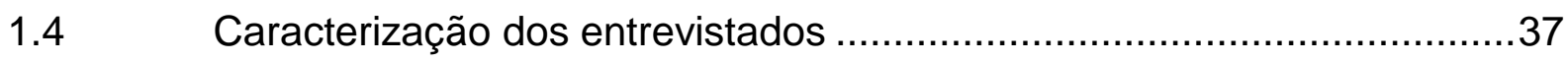

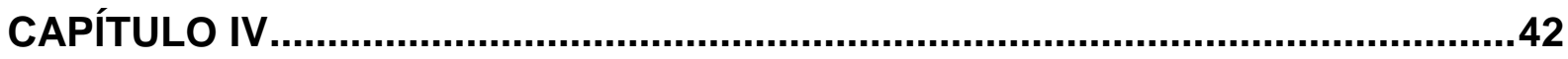

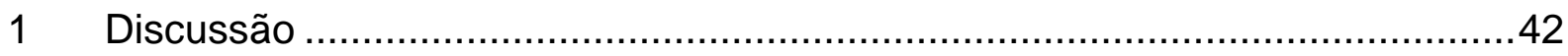

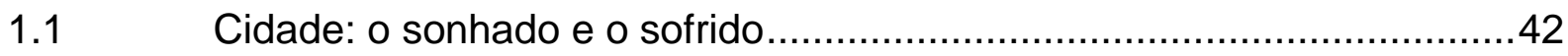

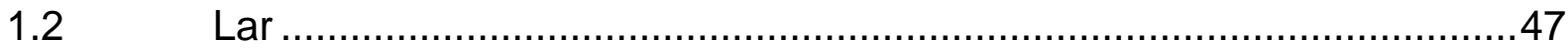

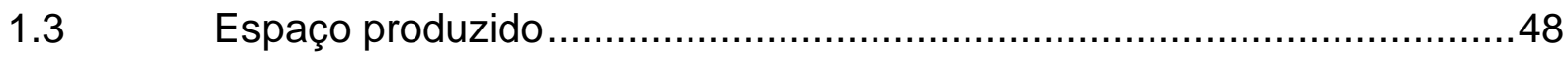

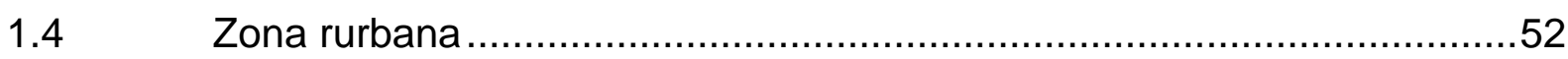


1.5 Relação entre habitantes da cidade: espaço legitimado pelo capital

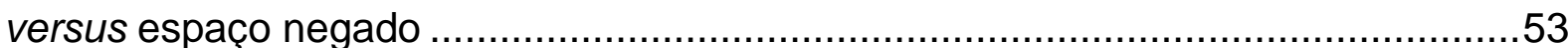

CONSIDERAÇÕES FINAIS ................................................................................57

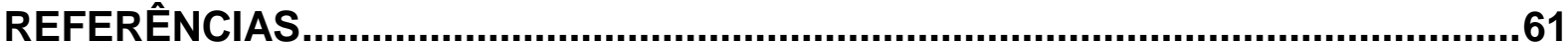

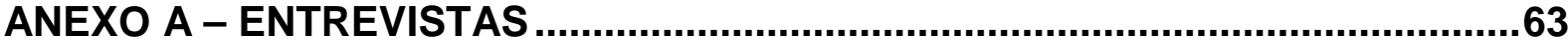




\section{INTRODUÇÃO: O TRABALHO E SEU OBJETIVO}

Este trabalho de pesquisa é sobre os espaços produzidos e a produção espacial ${ }^{1}$ daqueles brasileiros a quem é negado o direito básico à apropriação do solo. Brasileiros que constroem espaços móveis, instáveis e não legítimos ${ }^{2}$, segundo uma perspectiva do capital imobiliário e, por conseguinte, da sociedade como um todo. Da sociedade porque produz, participa e alimenta as regras do sistema capitalista e do sistema de produção, por intensificar e reconfigurar tal contexto de desigualdades sociais, econômicas e espaciais.

Os brasileiros que produzem os espaços não legítimos são aqueles com os quais qualquer um se depara no seu cotidiano, mas que nem sempre são vistos; os que moram pelas ruas e dormem sobre papelão em baixo de marquises; que habitam em acampamentos feitos com lonas plásticas nos desvãos desocupados do espaço urbano; ou mesmo aqueles que foram jogados nas periferias em precárias habitações construídas por eles próprios com lata, papel, plástico encontrados no lixo. Esses brasileiros, vistos como ilegítimos aos olhos do sistema capitalista, que

\footnotetext{
1 "O espaço, primeira categoria do pensamento geográfico, é então categorialmente concebido como resultado do ato da produção. Mas, há aqui uma peculiaridade: o espaço produzido o é a partir do espaço existente, ou seja da transformação de espaço anterior (...) Por isso, produção do espaço e espaço produzido são dois momentos diversos de uma mesma sequência: processo e estrutura. $O$ trabalho produz o espaço, a partir do espaço existente anteriormente e o resultado, como espaço produzido, repercute sobre o anterior. Quer dizer, o processo determina a estrutura, que se volta sobre aquele" (SILVA, p. 6)

${ }^{2}$ A classificação espaços não legítimos diz respeito aqueles espaços constituídos por moradias não reconhecidas como válidas, moradias ilegais porque não foram adquiridas pelo poder de compra. Para elucidar a categoria lança-se mãos das ideias de Carlos (2007, p. 47): "Para ter-se acesso a um pedaço de terra é necessário pagar por ele (através da venda ou do aluguel) pelo fato de que, na sociedade atual, o uso é produto das formas de apropriação (que tem na propriedade privada sua instância jurídica). O preço é expressão de seu valor". Ou ainda, segundo a mesma autora: "A propriedade privada de parcelas do espaço aparece como título jurídico que sacramenta o processo da apropriação que está na base do sistema capitalista de produção - tanto na produção material quanto da produção da vida" (CARLOS, 2007, p. 53). Assim, é não legítimo porque contraria a lógica do sistema de produção de mercadorias e consumidores, para o qual só tem poder quem tem dinheiro. Analisando a relação de poder, legitimidade e autoridade, Graciela Di Marco (2005, p. 12) coloca que: "La legitimidad es el reconocimiento por parte del grupo hacia quien o quienes tienen poder (WEBER, 1964, ); si se identifica autoridad con legitimidad: la gente reconoce y obedece voluntariamente a quienes la conducen. Se explica la legitimidad por la obediencia voluntaria, porque se reconoce el derecho de pedir obediencia. O, en palabras de Sennett (1980), la autoridad significa un proceso de interpretación y de reconocimiento del poder". "A legitimidade é o reconhecimento por parte do grupo sobre aquele ou aqueles que possuem o poder (Weber, 1964); assim, se identifica autoridade com legitimidade: as pessoas reconhecem e obedecem voluntariamente a quem as conduzem. Se explica a legitimidade pela obediência voluntária, porque se reconhece o direito de pedir obediência. Ou, nas palavras de Sennett (1980), a autoridade significa um processo de interpretação e de reconhecimento do poder" (Tradução Livre).
} 
norteia o modo de produção e as relações em sociedade, acabam ocupando a condição de "quase não pessoas", vivem em situação precária desprovidos até mesmo dos direitos básicos e do acesso à cidadania.

Para exemplificar essa categoria de "quase não pessoas" e o não acesso a cidadania, apontamos uma característica marcante na maioria dos entrevistados da pesquisa feita para elaborar esse trabalho: muitos deles relataram não ter qualquer documento, nem sequer a certidão de nascimento, um documento básico de identificação para pessoas adultas no país. Uma das entrevistadas chegou a dizer que, tendo perdido o documento não conseguiu tirar a segunda via por ter se esquecido qual era seu nome todo. No Jornal do Senado - Brasília, 16 de agosto de 2004 pode-se ler o seguinte sobre a certidão de nascimento:

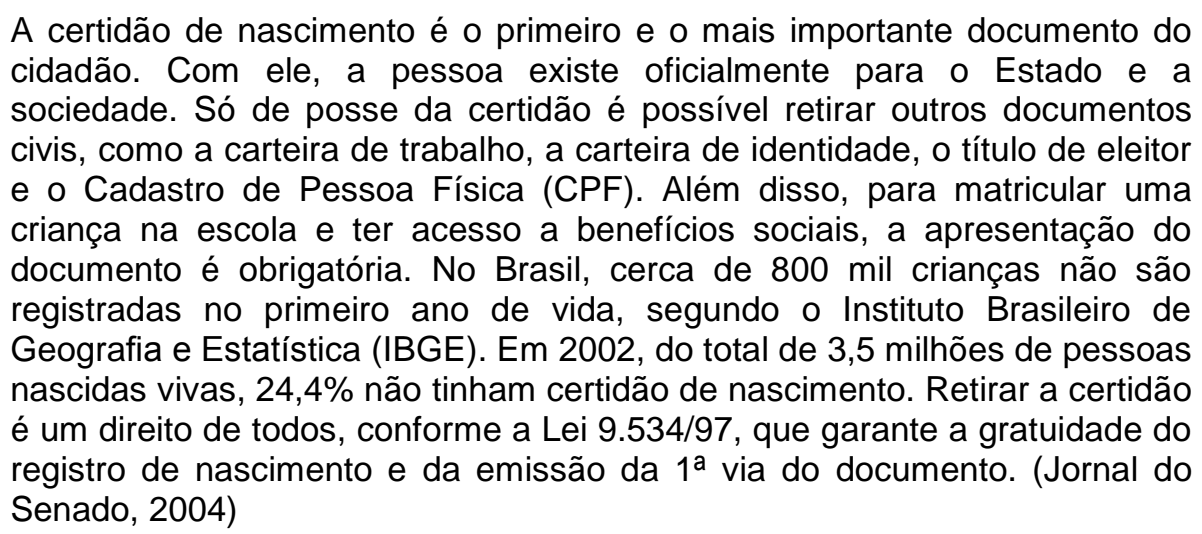
Brasileiros que assumem estratégias de sobrevivência diante das condições subumanas que enfrentam em seu cotidiano reproduzem a vida de forma diferenciada do que ocorre no restante da cidade. O espaço urbano é produzido de forma heterogênea, é um espaço híbrido, cheio de contrastes, pois é a materialidade das desigualdades sociais e econômicas existentes na sociedade ${ }^{3}$.

As desigualdades de renda gritantes reproduzem espaços e modos de vida paradoxais, mas também indissociáveis. As pessoas e os espaços produzidos nesse espaço híbrido são tidos também de forma desigual, com valores e importância distintos. Armando Corrêa da Silva (p. 7) coloca que o valor do espaço reside numa dupla existência, com características naturais como, por exemplo, aspectos da

\footnotetext{
${ }^{3}$ A desigualdade é a hierarquização da diferença visando à apropriação, manutenção e usufruto do poder. A desigualdade é um fenômeno antigo nas sociedades humanas que se manifesta nas relações de gênero, etnia, cor e se materializa nas estruturas do espaço urbano: "As contradições sociais emergem, na paisagem, em toda a sua plenitude, os contrastes e as desigualdades de renda afloram" (CARLOS, 2007, p. 77).
} 
fertilidade do solo e, também, como espaço construído, que consistiria na infraestrutura e serviços. Segundo o mesmo autor as diferentes formas de apropriação do espaço são decorrentes da divisão da sociedade em classes.

O valor diferente dado aos espaços é associado também aos habitantes que os produzem. Neste contexto, os modos de tratamento, status, poder aquisitivo, poder de fala, exercício da cidadania não são iguais nos diferentes espaços da cidade. 0 que faz parecer, que os habitantes da periferia são menos "valorizados" do que os habitantes das áreas nobres. Sobre as diferentes formas de tratamento das pessoas em decorrência do seu espaço vivido:

\begin{abstract}
As pessoas são tratadas de forma diferenciada em função de sua aparência, das roupas que vestem do carro que dirigem, lugares onde passam férias, restaurantes que frequentam, cartões de crédito que usam. Até as filas de banco são diferenciadas pelo uso do cheque especial. A mídia produz um modo de vestir e de sentir dentro de determinada roupa; e até um modo de sentir out. $O$ homem passa a ser visto, avaliado e respeitado a partir de uma aparência produzida. São os valores urbanos. É a sociedade urbana que os impõe. (CARLOS, 2007, p. 21).
\end{abstract}

Os espaços de menor valor são os espaços móveis e instáveis conceituados nesse trabalho como espaços negados, definição desenvolvida mais adiante. As características de instabilidade e mobilidade associadas a essa definição referem-se ao fato desses espaços serem constantemente desapropriados forçando quem neles vive a se realocar para outros pedaços de solo e reproduzir novamente os mesmos espaços, com as mesmas condições que possuíam antes ou com a ausência de quaisquer condições. Por exemplo, no período de realização da pesquisa empreendida para esse trabalho os acampamentos visitados foram destruídos e reconstruídos algumas vezes, mudando de local e variando quanto ao número de moradores.

Apesar dessa materialidade incerta, esses espaços são paradoxalmente fixos porque continuam existindo, pois, na falta de políticas sociais efetivas os acampamentos de plástico estabelecem-se a alguns metros ou quilômetros dos locais em que sua existência foi uma vez negada. Confirmado pelo depoimento do próprio gerente de vigilância da Subsecretaria do Sistema Integrado de Vigilância do Uso do Solo (SIV- Solo) ${ }^{4}$ em 2002: "A gente tira todo mundo de lá, mas logo em

\footnotetext{
${ }^{4}$ Segundo informado no próprio site do GDF: "Subsecretaria de Defesa do Solo e da Água (Sudesa) é o resultado da junção de outros dois órgãos, o SIV-Solo e o SIV-Água, que funcionavam
} 
seguida eles estão acampados em um lugar próximo. Não tem fim: é como briga de gato e rato" (PEREIRA, 2008, p. 107).

A instabilidade e a mobilidade dos acampamentos leva a crer que diante do poder público sua situação e seus espaços não são considerados. A existência dos acampamentos só é percebida e avaliada pelo valor do solo que ocupam o qual, segundo a ótica do sistema capitalista, podia ser melhor aproveitado se utilizado para promover o lucro.

Por isso, os espaços negados incomodam, pois diminuem o valor do solo e dos imóveis que estão a sua volta, geram tensão e conflito constante entre aqueles que pretendem escondê-los (como se esconde vestígios de um crime) e aqueles que precisam do solo (como qualquer outra pessoa) para "construir" um lugar que lhes "pertença"; para sobreviver. Sobre a necessidade humana de um lugar para se estabelecer e reproduzir a vida Carlos argumenta:

O homem necessita de um espaço para viver, mesmo que este seja debaixo de alguma ponte. Ele necessita de um lugar para comer, dormir, descansar, enfim, um lugar usado para reposição de energia, da reprodução da força de trabalho e da espécie (Carlos, 2007, p. 42-43).

A pobreza incomoda os moradores dos espaços legitimados pelo capital, levando a pensar que seja vista quase como um crime ${ }^{5}$. Tal fato pode ser percebido até mesmo na postura do Estado, que promove políticas punitivas para a população de rua, conforme constata Cavaignac (2009, p. 95): "As políticas públicas destinadas à população de rua, na verdade, transformaram-se em uma política de combate aos pobres (remoção, recolhimento e expulsão)". Existe um esforço enorme para esconder e afastar a pobreza, materializada nos acampamentos de plástico. Talvez isso se deva porque nesses momentos nos damos conta de que algo não está bem,

desde 1993. A união possibilitou um melhor aproveitamento do trabalho realizado. Atualmente, as equipes de fiscalização trabalham diariamente, no combate às novas invasões e no controle das que já existem. Por isso, a vigilância não para nem aos finais de semana e feriados". (http://www.ssp.df.gov.br/003/00301009.asp?ttCD CHAVE=62741)

O Sistema Integrado de Vigilância do Solo - SIV-SOLO, extinto em 2007, era o sistema misto de vigilância do solo, que abrangia várias instituições governamentais e tinha por finalidade combater a ocupação ilegal e/ou irregular de terras públicas ou privadas (IBRAM, 2009).

${ }^{5} \mathrm{~A}$ vida dos moradores dos espaços negados é marcada por uma tensão permanente que alude à vida de criminosos. Segundo Pereira: "a realidade mostra com eloquência que todas as horas de suas vidas são dedicadas as suas estratégias de sobrevivência e ao enfrentamento das consequências que estas geram como os ataques de outros moradores de rua; o controle policial; a fiscalização constante dos órgãos do governo; os efeitos do medo, da desconfiança e da discriminação de grande parte da população, chamada de 'incluídos sociais'" (PEREIRA, 2008, p. 119). 
como afirma Porto (2009, p. 16): "percebemos, ainda que de forma fugaz, que há 'muita coisa errada', e nos movemos em nossas poltronas esboçando gestos de horror e desagrado". Apesar do mal-estar ou mesmo devido, exatamente, a ele os anônimos e o espaço que produzem são tornados "invisíveis" como se isso pudesse eclipsar o problema social que representam. José Carlos Rodrigues (1999, p. 104) exemplifica essa ideia:

[...] os ricos, isolados em seus veículos particulares, passarão a ter a sensação de uma inédita liberdade de movimento, mas também deixarão de acreditar que a paisagem urbana circundante tenha qualquer significado além de ser um mero meio, cuja finalidade é o próprio deslocamento. A velocidade e o encapsulamento em seus veículos fazem desaparecer a paisagem humana. Este distanciamento não representa apenas expulsão, gesto de força ou pragmatismo individualista. Contém uma sutil dimensão de sensibilidade, pois é muito mais fácil ser cruel, rigoroso ou objetivo com aqueles que são anônimos e que não podemos ver.

A ênfase em afastar a pobreza, em torná-la invisível, é um dos elementos que pode explicar o sistemático direcionamento de contingentes populacionais para as periferias dos centros urbanos, o que gera, também, um constante conflito na cidade pelo "direito à cidade". Trabalhando essa categoria analítica de Henri Lefebvre, Ana Fani Carlos (2005, p. 227-228) expõe: “'direito à cidade`como categoria central da análise, introduz o negativo - a revolta da sociedade contra aquilo que segrega, afasta, impede a realização da vida na cidade".

contexto de instabilidade e mobilidade dos anônimos, marginalizados nos espaços da cidade, e da negação de seu acesso ao exercício pleno da cidadania materializase na conformação do espaço urbano, como aponta Carlos (2006, p. 51): "Nesta condição a morfologia urbana espelha uma hierarquia social definida, na medida em que a habitação é a forma mais imediatamente visível das diferenciações de classe no espaço".

É sobre este espaço contraditório e desigual que o presente trabalho lança seu olhar. Sobre a apropriação e produção espacial na cidade que envolve as relações entre os diversos atores atuantes no espaço urbano. Relação que está intrinsecamente associada ao poder de compra, poder que se confunde e substitui os direitos e deveres dos cidadãos. Quem tem mais poder de compra, tem mais direito diante à sociedade, mais direito perante a justiça e mais direito à proteção, respeito, reconhecimento: "O homem passa a ser avaliado pela sua capacidade de 
'ter coisas'. O outdoor da propaganda das camisas/calças da USTOP é bastante sintomático desse tipo de relação: 'O MUNDO TRATA MELHOR QUEM SE VESTE BEM”" (CARLOS, 2007, p. 20).

A compra passa a determinar os espaços públicos e privados, os espaços legítimos e não legítimos para moradia, os excluídos e os incluídos espacialmente. Exclusão ou inclusão espacial são determinadas e determinantes na exclusão ou inclusão em outras esferas, como a social, econômica, cultural: "O uso diferenciado da cidade demonstra que esse espaço se constrói e se reproduz de forma desigual e contraditória. A desigualdade espacial é produto da desigualdade social" (CARLOS, 2007, p. 23).

No presente trabalho analisaremos a contradição na produção do espaço urbano, assim como o significado de cidade a partir da perspectiva de pessoas que migraram de áreas menos urbanizadas em busca de melhores condições de vida. Entretanto, ao chegarem à cidade, se depararam com o sofrido e acabaram por integrar a população de rua do Plano Piloto de Brasília.

O termo população de rua é utilizado neste trabalho, pois abarca os dois grupos sociais analisados na pesquisa: os moradores de rua, aqueles que não possuem outro local de moradia e os moradores por temporadas que permanecem nos centros das cidades para conseguir emprego, trabalhar e sobreviver, retornando as suas casas apenas esporadicamente. No entanto, nesse segundo caso, apesar de possuírem outra moradia, mesmo que seja só alugada, necessitam estar nos centros das cidades, pois a maior parte deles sobrevive do trabalho com o lixo e da caridade recebida ${ }^{6}$. Conforme afirma Pereira (2008, p. 71-72), nas ruas do Plano Piloto de Brasília, existem três grupos sociais:

O primeiro é composto por pessoas ou famílias que residem nas cidades satélites, no entorno do Distrito Federal ou em cidades de Estados vizinhos, como Bahia e Minas Gerais, e que, em épocas comemorativas - Natal, Dia das Crianças, Corpus Christi, Páscoa - montam barracos nas ruas da cidade com o intuito de receber doações [...]. O segundo grupo é constituído de populações residentes fora do Plano Piloto, que vêm a Brasília para trabalhar ou conseguir outros meios de sustento. Por não possuírem

\footnotetext{
6 "Segundo eles, o lixo do Plano Piloto é mais rico, dá mais dinheiro, e vigiar carro em cidades satélites não dá dinheiro algum. Portanto, precisam trabalhar em Brasília para sobreviver. Contudo, se voltassem para casa após o trabalho, gastariam $\mathrm{R} \$ 10,00$ por dia, dinheiro que não possuem. A solução encontrada foi morar nas ruas do Plano Piloto e, duas ou três vezes por mês, voltar para casa. Somente ali é que conseguem dormir (PEREIRA, 2008, p. 73-74).
} 
dinheiro suficiente para o transporte diário, dormem na rua durante a semana e, quando podem, passam alguns dias por mês em suas casas [...]. O terceiro grupo é composto de pessoas que vivem e trabalham nas ruas do Plano Piloto. Como precisa morar em Brasília, este grupo, ao contrário dos anteriores, procura instalar seus barracos longe das vistas dos transeuntes e, principalmente, do Governo.

Como mais da metade da população de rua analisada na pesquisa estava estabelecida no centro da cidade por mais de dez anos, seja periodicamente ou definitivamente, não consideramos que possam ser classificados em situação de rua $^{7}$. Quando o período se estende por anos ou décadas, nas quais se vive nas mesmas condições, não se pode caracterizá-lo como um fenômeno passageiro e aleatório.

Dentre os habitantes definidos como população de rua estudamos na pesquisa os migrantes de outras regiões que se autodenominam "recicladores". A categoria "recicladores" emergiu do discurso nativo no âmbito da pesquisa e revela a vontade dos anônimos pesquisados em não serem identificados com outras categorias de pessoas que também percorrem os interstícios da cidade, tal como: os abandonados, doentes, os com transtornos mentais, os que vêm de outras cidades temporariamente em busca de esmolas, que brigaram com a família, perderam o emprego, alcolistas, drogadictos e quantos mais perambulam pelas ruas. Categorias da população de rua ${ }^{8}$ que, devido à falta de políticas públicas especializadas, interesse do Governo, não há como serem erradicadas, pois precisam estar no centro porque sobrevivem do lixo, das esmolas e da caridade.

\footnotetext{
${ }^{7}$ Pereira distingue os conceitos população em situação de rua, moradores de rua e população de rua, mostrando que cada conceito carrega um significado distinto: "Recentemente, em São Paulo, foi proposta a utilização da expressão pessoas em situação de rua, com a intenção de destacar o caráter processual do fenômeno [...] Todavia, não há estudos que comprovem a reversibilidade dessa situação, melhor dizendo, não há como medir as chances reais de uma pessoa sair da rua. Talvez, as pessoas que realmente estejam em situação de rua, sejam exceções. E, finalmente, o termo morador de rua, não parece apropriado devido à heterogeneidade desse universo populacional. Muitas pessoas não residem, de fato, na rua, mas, para poupar o dinheiro do transporte, passam alguns dias do mês. Assim, por falta de um termo mais preciso, optou-se por definir essas pessoas como população de rua." (PEREIRA, 2008, p. 30-31)

8 "As diferentes nomenclaturas utilizadas para conceituar esse grupo de pessoas no decorrer da história, ilustram a transformação na forma de se encarar o fenômeno. Os termos utilizados há alguns anos para caracterizar esse grupo social eram bastante pejorativos: mendigos, pedintes, vagabundos, viciados, maltrapilhos, carentes, loucos, entre outros. Em compensação, hoje surgem novas terminologias, como povo da rua, população de rua e sofredores de rua, que retiram do sujeito a culpa pela sua situação de penúria e o elevam à condição de detentor legitimo de direitos e principalmente porta-voz das suas necessidades e demandas" (PEREIRA, 2008, p. 70).
} 
De acordo com Cavaignac (2009) o Estado tem tido em relação à população de rua uma postura punitiva de contenção e repressão com o controle social tomando o lugar da política social. Essa mesma autora lembra que essa postura punitiva do Estado em relação à população de rua é um retorno do velho discurso liberal, presente na Lei dos Pobres de $1834^{9}$, o qual identificava a pobreza como uma degeneração individual:

A concepção orientadora da atuação da política pública contemporânea para a população de rua é a de que este é um grupo desviado, que não gosta de trabalhar, que está na rua porque é vagabundo, então por que vai se fazer política para esse público, que não vai "valorizar"? Essa é a ideia do Estado penal. Seu princípio é tão diferente assim da resposta política aos pobres no século XIX? (CAVAIGNAC, 2009, p. 95)

No entanto, a auto classificação "recicladores" agrega e perpassa todos os tipos designados por tais classificações: moradores que habitam a rua por temporadas para trabalhar e receber caridade, alcolistas, drogadictos e outros.

Dessa forma, a pergunta de partida do trabalho se refere ao imaginário sobre a cidade da população de rua e o espaço por eles produzido. Apesar de ser fácil constatar as dificuldades por eles enfrentadas ao se instalarem no novo ambiente, 0 fluxo populacional para as grandes cidades continua. Por quê? De acordo com Lefebvre (1991, p. 5-6):

Os violentos contrastes entre a riqueza e a pobreza, os conflitos entre os poderosos e os oprimidos não impedem nem o apego à Cidade, nem a contribuição ativa para a beleza da obra. No contexto urbano, as lutas de facções, de grupos, de classes, reforçam o sentimento de pertencer [...]. Esses grupos rivalizam no amor pela sua cidade.

Este panorama paradoxal caracteriza esta monografia que pretende levantar a percepção de migrantes "voluntários" da área rural que atualmente habitam o espaço urbano, buscando investigar sua motivação para a migração, sua expectativa antes e depois do deslocamento para a cidade, tomando como base para análise sua concepção sobre o que seja cidade. Essa indagação é o que justifica o levantamento

\footnotetext{
${ }^{9}$ De acordo com Cavaignac (2009, p. 37-38): "A Lei de 1834 carregava em si os princípios do liberalismo econômico, atendendo às necessidades industriais de se extinguir a proteção aos trabalhadores, como uma forma de lançá-los à livre competição no mercado de trabalho. A assistência social revestiu-se de um estigma e precisar depender dela era um sinal de vergonha. Inclusive, era este ponto que diferenciava os trabalhadores dos indigentes. Os primeiros sobreviviam do trabalho e estes últimos da assistência (mínima). Para os trabalhadores, principalmente, recorrer à assistência era considerada uma infâmia".
} 
teórico e o trabalho de campo, que se equilibra entre o descortinar do sonho e o enfrentamento da realidade.

Assim, o objetivo primeiro é entender o que faz do espaço urbano um local catalisador de sonhos e como esses sonhos se materializam em sofrido, num segundo momento, quando os migrantes voluntários chegam às cidades e se estabelecem nelas, produzindo os acampamentos de plásticos e se defrontando com a realidade contraditória que nela encontram.

A hipótese deste trabalho é que mesmo que migrar signifique constituir os espaços negados e ter as necessidades sucessivamente negligenciadas pelo Estado bem como pelo restante da sociedade, os contingentes populacionais continuam se deslocando em direção às cidades mais urbanizadas, porque ainda que não adquiram toda a melhora em suas vidas que imaginavam, ao menos assim estão mais perto, geograficamente, de todos os bens e serviços que almejam. Dessa forma, vislumbram a possibilidade, mesmo que apenas fictícia, de levar um modo de vida urbano.

O estudo dividiu-se em quatro capítulos. No Capítulo I traz um breve histórico abordando questões referentes à origem das cidades: como o imaginário sobre a vida urbana vem sendo construído e exercendo influência nas migrações populacionais no decorrer da história. O Capítulo II apresenta o marco teórico, elucidando categorias analíticas e conceitos utilizados na análise das entrevistas. No Capítulo III é descrita a metodologia, exemplificando o método de trabalho bem como a caracterização da pesquisa, do campo e dos entrevistados. O Capítulo IV é reservado para a discussão e reflexão com base nas entrevistas. A discussão é agrupada nos seguintes temas: cidade, o sonhado e o sofrido; espaço produzido; zona rurbana; relação entre habitantes da cidade: espaço legitimado pelo capital versus espaço negado. 


\section{CAPÍTULO I}

\section{BREVE HISTÓRIA DA IDEIA DE CIDADE}

A cidade como produto das relações humanas e reflexo de suas desigualdades se reproduz como projeção das disparidades de acesso ao poder. Para exemplificar essa reflexão, citamos Carlos (2004, p. 15) a qual coloca que a cidade é decorrente de um estágio de produção da sociedade e pode ser entendida dialeticamente enquanto produto, condição e meio para a produção das relações sociais.

A construção espacial desigual é histórica e intrínseca aos sistemas constituídos em sociedades estamentais e de classe. As desigualdades inscrevem-se no âmago da ideia de cidade, estando presentes em todas as aglomerações urbanas ao longo da história, inerentes, então, à própria definição de cidade. Para Sposito (2008, p. 16), a sociedade de classes e a divisão do trabalho são elementos necessários e indispensáveis para a origem da cidade, caracterizando sua gênese.

A diversificação das atividades, associada à hierarquia, estruturam a sociedade de classes, refletindo, então, no processo de formação das cidades. Para Carlos (2007), a origem da cidade se confundiria com o princípio de uma hierarquização social, à qual, no entanto, a precede historicamente. Assim, a mesma autora vincula a existência da cidade aos seguintes elementos: "a) divisão do trabalho; b) divisão da sociedade em classes; c) acumulação tecnológica; d) produção do excedente agrícola decorrente da evolução tecnológica; e) um sistema de comunicação; f) uma certa concentração espacial das atividades não-agrícolas" (CARLOS, 2007, p. 59$60)$.

Mesmo que o fenômeno da desigualdade já seja fato comprovado na História, tanto nas áreas rurais quanto nas urbanas, nas cidades atuais esse fenômeno parece se intensificar seja em função da densidade demográfica, seja pela intensificação das assimetrias propiciadas pelo sistema econômico, seja porque as ideias de igualdade se tornaram correntes em nossa sociedade. Porém, como a sociedade de classes e a divisão do trabalho são também elementos inerentes ao sistema capitalista poderse-ia dizer que as desigualdades que sempre existiram foram maximizadas com o capitalismo, materializadas e concentradas na cidade. 
Ainda que se considere que o desenvolvimento desigual seja mais antigo do que o capitalismo, para Armando Corrêa da Silva (p. 8) o capitalismo herda as desigualdades do passado, uniformiza o mercado no centro e distribui as desigualdades na periferia como um sistema de fluxos que drena as riquezas da periferia ao centro. Carlos (2006, p. 49) elucida essa relação do capitalismo e da produção da cidade de forma bem clara:

O processo de produção da cidade desemboca no capitalismo na reprodução da cidade enquanto mercadoria, como extensão do mundo da mercadoria, nesta condição o acesso à terra urbana, imersa no universo da troca está subjugado ao mercado, ao universo da troca. Deste modo este processo realiza a propriedade privada enquanto mediação entre o indivíduo e o mundo dos objetos, entre a necessidade e a sua satisfação, e vai limitando o sentido da cidade enquanto criação e uso.

Podemos entender melhor a apropriação e produção espacial, inerente ao sistema capitalista, lançando mãos dos conhecimentos de Thomaz Júnior (1991, p. 21), o qual considera que "a relação homem-meio na sociedade de classes (esta de que fazemos parte) é mediada pela propriedade privada das condições de existência, portanto uma relação ecológica (histórica) de poder". Essa relação de poder está presente não só na apropriação espacial, mas também nas relações interpessoais, na cultura e na linguagem, pois, o poder é indissociável da vida humana em sociedade: "o poder é inevitável e, de modo algum inocente. Enfim, é impossível manter uma relação que não seja marcada por ele" (RAFFESTIN, 1993, p. 159). No sistema capitalista esse poder é definido pelo acesso ao capital, a possibilidade de adquirir bens e poder usufruir de serviços. Tal fator é determinante na apropriação e produção dos espaços da cidade já que, determina a localização em áreas privilegiadas, urbanizadas ou nas periferias.

Segundo Rodrigues (1999) as características das cidades foram se alterando ao longo da história e, na modernidade, modulando-se às necessidades e aos imperativos do sistema capitalista. Inicialmente, a cidade estava permeada do campo e esses dois espaços se misturavam, sendo fenômeno moderno a cidade que finge desconhecer o campo e até mesmo o nega, quando se olvida a interdependência entre os dois espaços. Em grande medida, as cidades medievais ainda desconheciam os espaços individualizados. Nelas os espaços públicos eram o lugar de maior importância, era onde ocorriam os encontros, as festas, comunicação, espaços onde se praticavam os ofícios. Nesse período, as moradias eram quase que 
amontoadas e a privacidade não era entendida culturalmente como tendo a importância que atualmente lhe conferimos. A vida privada, tal como a conhecemos, é um fenômeno moderno, construído ideologicamente junto com o surgimento da ideia de indivíduo e os desenvolvimento do capitalismo. Na Idade Média, as casas, tanto dos ricos como dos pobres, eram constituídas com cômodos que serviam para todos os usos, como explica aquele mesmo autor:

[...] o desejo de intimidade é uma invenção das classes dominantes, ponto central de uma mentalidade individualista e pedra angular de um sistema econômico e político. Não é apenas um progresso optativo: representa uma visão de mundo, a que cedo ou tarde todos deverão se submeter. (RODRIGUES, 1999, p. 106)

Essas transformações rumo ao imaginário individualista, no entanto, não alteraram as representações que as pessoas concebiam desde a Antiguidade sobre a cidade. Ao contrário, cada vez mais, a cidade foi se consolidando como o lugar de moradia das elites cultas, se contrapondo à ideia de campo, que foi se tornando sinônimo de local de moradia de pessoas ignorantes, iletradas, viciosas, perigosas, sujas, acusadas de permanecer mais próximo do animal que do homem ${ }^{10}$ (Rodrigues, 1999, p. 108). As palavras: urbano, urbanidade, urbanizar, são na nossa sociedade sinônimos de: afabilidade, civilidade, cortesia, educação, polidez, civilizar, educar, ilustrar, instruir, se contrapondo, segundo essas mesmas definições, ao que seria intrínseco do meio rural: campesino, rústico, descortês, deseducado, grosseiro, impolido, mal-educado (INSTITUTO ANTÔNIO HOUAISS, 2003, p. 680).

Compartilhando da ideia de que a cidade não é apenas a materialidade construída, mas também carregada de ideologia Carlos (2007, p. 26) coloca que: "A cidade é modo de viver, pensar, mas também sentir. O modo de vida urbana produz ideias, comportamentos, valores, conhecimentos, formas de lazer, e também uma cultura". A cidade é constituída de símbolos, das representações coletivas, do imaginário e

10 Tal assertiva parece confirmada no personagem Jeca Tatu, criada por Monteiro Lobato na década de 20 do século $X X$ no romance Urupês. Baseado no perfil trabalhador rural paulista, de uma região particularmente desassistida pelos poderes públicos, Jeca Tatu representa a pessoa pobre, quase ao ponto da indigência, ignorante e descuidada quanto aos hábitos de higiene adotados no meio urbano. Esse personagem reforça o estereótipo do "caipira atrasado", atribuída ao habitante rural brasileiro. Tal representação desairosa é fortalecida ainda pelo fato do autor identificar o personagem, inclusive, como o principal responsável pelos problemas da agricultura no país naquele período. 
dos sonhos. Por isso é fundamental fazer-se uma análise da ideologia envolta na compreensão de cidade, desenvolvida sobre tal contexto histórico.

A conceituação da ideia de cidade em diferentes autores aponta para a existência tanto de elementos materiais, como a infraestrutura, quanto imateriais, como o acesso ao trabalho qualificado, ao comércio, ao lazer, aos serviços de saúde e educação que, neste último exemplo, são identificados como pontos constituintes da condição de cidadania. Exemplificando os aspectos materiais e imateriais, atribuídos à cidade, citamos Carlos (2007, p. 46) quando coloca que: "[...] a cidade é meio de consumo coletivo (bens e serviços) para a reprodução da vida dos homens. É o lócus da habitação e tudo o que o habitar implica na sociedade atual: escolas, assistência médica [...] atividades culturais e lazer, ócio, compras.”.

No Brasil esse imaginário em torno da cidade é enfático porque as cidades sempre tiveram um papel de relevância mesmo no mercantilismo, quando a economia tinha unicamente um caráter agroexportador. Francisco de Oliveira (1982, p. 37) chega a dizer que, talvez, o campo nunca tenha de fato controlado o Estado no Brasil, mesmo considerando a característica agrícola dos ciclos econômicos brasileiros:

[...] porque vai ser nas cidades que se localizarão tanto os aparelhos que fazem a ligação da produção com a circulação internacional de mercadorias quanto os aparelhos do Estado - do Estado colonial português, em primeiro lugar, e depois do Estado brasileiro - que tem nas cidades, evidentemente, a sua sede privilegiada.

O conjunto de fatores que historicamente condicionou o imaginário das sociedades ocidentais desde a Antiguidade, anteriormente explicitados, levou à supervalorização da cidade, que passou a ser vista como o lócus do desenvolvimento, prosperidade, acesso à educação, saúde, riqueza; em suma, da civilidade. A influência desse imaginário foi se consolidando durante os séculos seguintes e, especialmente, a partir da Revolução Industrial. Com o conhecimento adquirido com a aplicação do método científico ocorreram transformações fundamentais na organização da cidade. Como exemplos, o aparecimento da educação e comunicação em massa, principalmente no que diz respeito às regras de higiene e saúde, bem como o afastamento de parte da elite do centro para os subúrbios (SJOBERG, 1977, p. 49).

Esses processos ajudaram a fortalecer ainda mais o imaginário de que estar na cidade implicaria, necessariamente, em ter acesso a tais condições e, 
consequentemente, ao exercício pleno daquilo que hoje se identifica como cidadania $^{11}$. O avanço tecnológico, o surgimento das fábricas, da luz elétrica, dos veículos a motor e dos meios de comunicação, intensificaram sobremaneira as transformações no espaço urbano e a forma da vida cotidiana nas cidades, gerando fascínio e atração crescentes nos tempos contemporâneos, o que atrai, continuamente, um contingente cada vez maior de pessoas.

A literatura define esse tipo de deslocamento populacional como migrações voluntárias, as quais são incitadas, principalmente, por motivos socioeconômicos. Conforme Scarlato (1996, p. 391), essa forma de migração é definida como movimentos em que os indivíduos são livres para escolher sua saída do local de origem, em direção a outros que Ihes permitam a realização da expectativa de melhoria no seu padrão de vida ${ }^{12}$. Assim diferenciam-se das migrações impelidas ou forçadas, causadas por fatores geológicos, climáticos ou sociais, como guerras, por exemplo.

No entanto, abriremos um parêntese crítico para essa definição de migrações voluntárias, apresentada por Scarlato (1996, p.391). Na pesquisa que originou esse trabalho observamos que as migrações apesar de não serem ocasionadas por uma força de ordem natural (alterações do meio físico) ou provocadas pela força das armas são - sim - migrações forçadas, na medida em que se percebe que esses migrantes saem de seus locais de origem por não terem meios materiais para sobreviver. De acordo com Santos (2007, p. 60):

11 Peluso aponta, em conversa 2009, que é importante considerar nesse período a expulsão de grandes massas de camponeses na Inglaterra, quando no início da Idade Moderna os campos foram cercados e a agricultura comunal tornada impossível, ocasionando grande êxodo rural. Sobre essa transição dos territórios comunais a propriedades burguesas e à privatização do direito ao espaço, com o desenvolvimento do capitalismo industrial, Frémont (1980, p. 44) argumenta: "A cidade eriça-se de paredes e signos que proíbem. A apropriação opera uma mutação dos valores do espaço. Privilegia nas relações homens/lugares o valor-mercadoria (regulamentado pelo direito)".

${ }^{12}$ Santos (2007) analisa o valor do homem e do Capital nos diferentes espaços estabelecendo que alguns lugares determinam a pobreza enquanto outros facilitam o acesso a serviços e bens teoricamente tidos como direito de todos. Assim, para entender as migrações é necessário: "uma explicação de maior alcance: trata-se não tanto de explicar porque as pessoas migram, quanto de saber por que elas permanecem, por que elas não migram. Isto é tanto mais importante quanto o fato de que não migrar significa, amiúde, condenar-se a ficar ainda mais pobre. Para muitos, ficar equivale a empobrecer-se dia a dia" (SANTOS, 2007, p. 109). 
As migrações brasileiras, vistas pelo ângulo da sua causa, são verdadeiras migrações forçadas, provocadas pelo fato de que o jogo do mercado não encontra qualquer contrapeso nos direitos dos cidadãos. São, frequentemente, também migrações ligadas ao consumo e à inacessibilidade a bens e serviços essenciais.

Nesta pesquisa verificou-se, por exemplo, que todos os entrevistados relatam a vontade de permanecerem na sua região de origem, mas que sentiram necessidade de se deslocar para conseguir condições que nas sociedades hodiernas são consideradas básicas para o desenvolvimento da vida, tal como acesso à saúde, educação, emprego.

Observamos, também, que as condições básicas que esses migrantes "voluntários" perseguem parece não se consubstanciar, de fato, para a maior parte da população migrante, que vem se deslocando para os centros urbanos ao longo do século XX. O que se pode perceber na atualidade brasileira, quando cerca de $83 \%$ da população vive nas áreas urbanas (IPEA, 2008, p. 3), é que os atributos dessa motivação primeira, o conforto, a infraestrutura, a melhor qualidade de vida, atribuídos à vida nas cidades, parecem cada vez mais distantes da realidade. Como afirma Santos, para os moradores com menor mobilidade social, neste trabalho identificados como população de rua, a cidade é impalpável e impõem-se agindo para limitar mais do que para facilitar sua ação, tornando esses moradores impotentes diante da multiplicidade das coisas que os cercam e de que poderiam dispor (SANTOS, 2007, p. 27).

A dificuldade de grande parte da população urbana de melhorar as condições de vida caracteriza uma verdadeira crise da cidade, tanto na dimensão teórica quanto na experiência prática. Vem ao encontro desta perspectiva a proposição de Lefebvre (1991, p. 13), segundo a qual a crise teórica poderia ser remetida às origens do conceito da cidade (da realidade urbana), composta de fatos, representações e imagens, emprestadas à cidade antiga (pré-industrial, pré-capitalista), mas em curso de transformação e de nova elaboração. A crise prática é representada pela deterioração do núcleo urbano e o transbordamento das periferias.

Os contingentes populacionais migrantes chegam às médias e grandes cidades com expectativas distintas das possibilidades reais que encontram e acabam por formar conglomerados de habitações carentes de infraestrutura básica, tal como, água 
encanada, luz, esgoto e asfalto. Exemplificando essa ideia podemos citar Carlos (2007, p. 48) sobre a distribuição das localidades por classes sociais na cidade:

À parcela de menor poder aquisitivo da sociedade restam as áreas centrais,
deterioradas e abandonadas pelas primeiras [parcela com maior poder
aquisitivo], ou ainda a periferia, logicamente não a arborizada, mas aquela
em que os terrenos são mais baratos, devido à ausência de infraestrutura, à
distancia das 'zonas privilegiadas' da cidade, onde há possibilidades da
autoconstrução - da casa realizada em mutirão. Para aqueles que não têm
nem essa possibilidade, o que sobra é a favela, em cujos terrenos, em sua
maioria, não vigoram direitos de propriedade.

Assim, muitas vezes os migrantes vivem em condições mais precárias do que as que desfrutavam antes de sair de suas localidades de origem, em busca de melhor qualidade de vida. Passam a produzir os espaços construídos de sonhos e expectativas que resistem, mesmo que inconscientemente, ao espaço-mercadoria. 


\section{CAPÍTULO II}

\section{MARCO TEÓRICO: O ESPAÇO NEGADO NA CIDADE}

O espaço geográfico, categoria de análise essencial e o objeto de estudo da Geografia teve seu conceito alterado nas diversas escolas dessa Ciência. No entanto, cada vez mais vem prevalecendo o conceito de espaço como categoria dinâmica que é elemento de ação, mas, também, que sofre ação na interação sociedade/solo. Nessa nova definição deve-se citar Milton Santos (1985, p. 5), que considera o espaço geográfico como instância ideológica da sociedade, tal como as instâncias econômica e cultural.

Essa terminologia geográfica se refere ao lócus onde se articula a vida, onde ocorre o cotidiano. Também Tonino Bettanini (1982, p. 29) descreve o espaço como o lugar comum, onde se fala e se vive. Todavia, faz também uma ressalva ao papel ativo desse lócus que, "não se constitui como cena vazia": é também agente de transformações, é aquilo que nele acontece. Carlos (2007, p. 73) caracteriza espaço como: "o lugar do encontro e o produto do próprio encontro".

Frémont (1980, p. 48) coloca que o primeiro espaço é o do seio materno, o corpo da mãe que carrega o feto e realiza pela placenta sua oxigenação: "é ao mesmo tempo invólucro, proteção, nutrição, comunicação [...] Não continuará o espaço a ser sempre um pouco isso?". O entendimento do primeiro espaço como o próprio corpo materno é muito interessante porque evidência, por um lado, o fato do espaço ser inerente ao corpo, mas existir a priori e, por outro, mostra como a produção espacial é um fenômeno dinâmico e constante em nossas vidas. O espaço geográfico existe e é produzido e reproduzido pelas sociedades mesmo que não tomemos consciência disso.

Cada sociedade, cultura, cada momento histórico e modo de produção econômico, condicionam a produção espacial de determinada forma. O espaço é, então, múltiplo e variável, pois é produzido como projeção das diferentes sociedades e momentos históricos. Analisando por uma perspectiva antropológica, Hall (1994, p. 188) observa que o espaço é um meio de comunicação, organizado de forma diferente em cada cultura. 
Muito do que acontece na utilização e organização espacial pode ser interpretado como indicação importante sobre os hábitos e modos de vida específicos de determinadas sociedades, marcando diferenças tanto entre as regiões, como entre as cidades e por fim, entre as pessoas. A cidade moderna, em que pesem os recursos materiais disponíveis, mostra-se um lugar também de desigualdade e pobreza, como escreve Carlos (2007, p. 42):

Por todos os lados vê-se a disparidade, a desigualdade entre o "rico" e o "pobre" e entre este e o "miserável absoluto" que mora embaixo das pontes ou nos bancos das praças. A disparidade expressa-se nas construções, nas existências e/ou qualidade da infraestrutura, na roupa e nos rostos.

Se cidade for sinônimo de infraestrutura, serviço e cidadania, pode-se pensar que muitas pessoas que vivem no espaço urbano não fazem parte da cidade. Entretanto, estão envolvidas na teia do espaço urbano e são funcionais ao sistema, apesar de Ihes faltar um lugar fixo de moradia e, por extensão, viverem sem condições de cidadania. São pessoas que habitam espaços negados, um dos mundos paralelos que é constituído por segmentos sociais que alimentam a cidade, reproduzida de forma desigual.

Este estudo é desenvolvido a partir de duas categorias analíticas, que orientaram a pesquisa de campo e a elaboração das reflexões dela decorrentes, desenvolvidas a partir dos marcos teóricos delineados na literatura: espaço legitimado pelo capital e sua sombra, espaço negado. Desenvolve-se entre essas duas formas de produção espacial a relação de resistência à ordem urbana, imposta pelo capital imobiliário. Tal relação é a expressão material das desigualdades de poder entre os habitantes da cidade que produzem esses distintos espaços. Para tanto, faz-se necessário contextualizar e caracterizar o solo onde se desenvolve a produção do o espaço legitimado pelo capital bem como do espaço negado.

Em relação ao uso e à propriedade do solo, o espaço legitimado pelo capital pode ser definido como aquele apropriado, legitimado pelo poder de compra. O espaço negado é aquele adquirido de forma ilegítima, segundo uma perspectiva do capital imobiliário. Ele não é programado ou nem mesmo planejado, constantemente é tomado e transformado simbolicamente em um lar para aqueles excluídos do direito à cidade. 
A ilegitimidade desse último ocorre tanto no imaginário como na dimensão concreta. No imaginário, os espaços negados são as áreas que não percebemos, os pedaços de solo da cidade que chamamos de vazios. Encontram-se também entre as construções, os monumentos, as pontes e viadutos, nas partes projetadas para serem inabitadas, construções funcionais públicas, que, muitos consideram, não deve abarcar a vida privada. São os lugares que vemos, mas que não enxergamos de fato, pois estamos habituados a ver só construções, placas, asfalto, espaço legitimado pelo capital. A ilegitimidade na dimensão concreta é demonstrada pela própria mobilidade e instabilidade desses espaços.

Em contrapartida, as apropriações legítimas do espaço, assim consideradas pela sociedade, são marcadas por edificações e outros elementos fixos de infraestrutura e arquitetura que conformam e organizam a utilização do espaço, definindo sua função. Diante desse pressuposto, a apropriação espacial apenas por pessoas não é considerada legítima pelos habitantes dos espaços legitimados pelo capital, tal como para o poder público.

Além desses conceitos-chave utiliza-se também o de zona rurbana para definir a localidade que carrega traços rurais muito fortes apesar de fazer parte do espaço urbano. Lefebvre (2001, p. 69) conceitua zona rurbana como: "o campo se perdendo no seio da cidade, com a cidade absorvendo o campo e perdendo-se nele [...] Os geógrafos encontraram, para designar essa confusão, um neologismo, feio porém significativo: o rurbano". Fora da dimensão da materialidade, a linguísta Stella Maris (2004, p. 52) discorre sobre o conceito de zona rurbana, apresentando-o como termo da antropologia social, que caracteriza as comunidades urbanas de periferia, onde há forte influência rural na cultura e na língua:

Os grupos rurbanos são formados pelos migrantes de origem rural que preservam muito de seus antecedentes culturais, principalmente no seu repertório linguístico, e as comunidades interioranas residentes em distritos ou núcleos semi-rurais, que estão submetidas à influência urbana, seja pela mídia, seja pela absorção de tecnologia agropecuária. (BORTONIRICARDO, 2004, p. 52)

Assim, neste trabalho, os espaços negados podem ser associados também ao conceito de zonas rurbanas, como definido nos dois modos acima. A população de rua pesquisada neste estudo é migrante de áreas rurais e, portanto, reproduz as características de seu processo de socialização nas suas inter-relações pessoais, 
mas, também, insere-se ativamente na teia do espaço urbano, mesmo que, diante da lógica do capital imobiliário, sejam trabalhadores marginalizados e produtores de um espaço alternativo.

Tal definição, que abarca os aspectos materiais e imateriais, objetivos e subjetivos, na produção do espaço está implicada na análise das práticas espaciais, nas condições de moradia e nas relações interpessoais, tanto no âmbito comunitário quanto familiar. As zonas rurbanas são espaços produzidos nas áreas urbanas que, no entanto, não usufruem da infraestrutura e dos serviços definidos como inerentes à urbanização, como educação e saneamento básico. Mesmo quando encravadas em áreas urbanizadas da cidade os espaços negados configuram-se como zonas rurbanas porque não são nem totalmente rurais nem absolutamente urbanos. Assim, o espaço negado é uma ilha rurbana dentro do espaço urbano, com características e formas de organização que remetem as áreas rurais e revelam a possibilidade de uma socialização comunitária, típica destas áreas. 


\section{CAPÍTULO III}

\section{METOdOLOGIA}

Antes de proceder à descrição objetiva das características do trabalho de campo, das técnicas utilizadas e dos processos de registro e análise dos dados levantados, parece relevante tecer algumas considerações a respeito do que motivou a escolha do campo de pesquisa, já que o projeto original que ensejou esse trabalho não contemplava o foco ora escolhido, os espaços negados nem, especificamente, aqueles que vivem e constroem tais espaços.

A identificação desse viés surgiu da dificuldade em selecionar quem seriam os informantes ideais para produzir uma reflexão sobre o imaginário que se constrói em torno da ideia de cidade. Como e onde encontrar e selecionar pessoas, como abordá-las e conseguir as entrevistas, revelavam-se preocupações que inibiam o início do trabalho de campo. Em meio às dúvidas surgiu a ideia de procurar pessoas cuja condição de vida no espaço urbano não estivesse contemplada por aqueles atributos relacionados à vida nas cidades. Essa opção parecia responder à necessidade de entender quanto o imaginário sobre a cidade influía nas escolhas pessoais sobre onde viver, bem como, de que forma as pessoas sob a influência desse imaginário percebiam suas vidas na cidade.

Assim, num primeiro momento, passei a vasculhar o espaço urbano em busca de "moradores de rua". Até então, também para mim, os espaços negados eram de fato invisíveis. Porém, a medida em que me dispus ao objetivo de localizá-los passei a vê-los por todas as partes da cidade de Brasília, no Distrito Federal, comecei a descobrir o tamanho enorme que esse novo mundo de acampamentos de plástico ocupa e quão desconhecido ainda é.

Depois de encontrar alguns deles, entendi que constituem, de fato, um universo urbano paralelo. Em algumas localidades, nos acampamentos escondidos nas áreas de cerrado, tive receio e medo de adentrar, devido a serem inalcançáveis ao olhar do transeunte comum. Não sabia como podia ser recebida por aqueles que lá viviam. Entretanto, para minha surpresa, nos cinco acampamentos em que me aventurei fui bem recebida, ao menos, na maior parte das vezes. 
Outro problema com o qual me deparei, além daquele inerente a começar a enxergar nitidamente esses espaços e encontrar seus retalhos pela cidade, foi o enfrentamento dos meus próprios temores e preconceitos. Além do medo real de ser agredida em locais ermos, percebi que havia em mim uma certa dificuldade em lidar com a pobreza daquelas pessoas. Um estranhamento quanto aos seus modos, fala e mesmo à forma como se relacionavam entre si.

Meu preconceito encontrava eco nos entrevistados; foi difícil convencê-los a participar da entrevista. Geralmente o grupo elegia um porta-voz, um escolhido pela maioria para dar a entrevista. Com olhares curiosos os demais ficavam à espreita vendo se também se submeteriam à bateria de perguntas ou se preservariam. Escutei comentários de pessoas que se negavam a fazer a entrevista dizendo que já tinham sido humilhadas demais e que, "já eram bastante degradadas". Compactuando as ideias de Michel Serres (2004) de que aprendemos para depois compreender, vivenciando no corpo tudo para depois compreender efetivamente, entendi que "o saber mergulha no corpo e dele ressurge" (SERRES, 2004, p. 75).

Posso dizer que essa pesquisa foi assim, impregnei-me de pedaços de solo desse espaço negado e tive o saber sacudido pela observação da vivência, que perpassou meu corpo todo, músculos, ossos, articulações, olhos para, depois, se tornar compreensão. A partir das experiências absorvidas nos dias de trabalho de campo e tantos outros, nos quais ando pela cidade, agora, com outros olhos, mais atentos e sensíveis a esses espaços negados e às vivências que neles se desenrolam, construí estas reflexões que, espero, estimulem a construção da cidadania a esses brasileiros invisíveis.

\subsection{Método de trabalho}

$\mathrm{Na}$ primeira etapa do trabalho foi realizada uma pesquisa prévia na literatura, destinada a embasar a reflexão sobre o imaginário dos entrevistados, possibilitando tanto contextualizar elementos da origem de suas representações, quanto fornecer, também, critérios para agrupar as falas em categorias analíticas pertinentes. Esse levantamento buscou identificar as condições objetivas que caracterizariam cidade, tal como conceitua a ciência geográfica. 
A seguir, foram identificados os entrevistados, em processo detalhado acima. $O$ levantamento de dados foi feito a partir de um roteiro de entrevista estruturado, com perguntas fechadas e abertas, estas últimas gravadas e transcritas na íntegra (anexas). Como elemento para análise e comparação das respostas foi verificado, ainda, a realidade objetiva dos locais de moradia desses migrantes entrevistados. Como era de se esperar todos os acampamentos são muito precários, transparecendo a marca da transitoriedade e instabilidade. Nenhum deles conta com a mínima infraestrutura básica, seja água, luz, esgoto apesar da proximidade a áreas urbanizadas.

Os dados obtidos na pesquisa de campo foram contrastados, posteriormente, com os parâmetros que definem teoricamente a categoria cidade, apresentados tanto no histórico quanto no marco teórico deste trabalho. Essa contraposição busca estabelecer uma aproximação analítica, voltada a apontar confluências e contrastes entre a ideia do que é cidade, na dimensão do imaginário, e o espaço que de fato é produzido na realidade por essas pessoas: entre o sonhado e o sofrido.

\subsection{Caracterização da pesquisa}

A pesquisa de campo de natureza qualitativa e descritiva foi realizada com moradores de áreas de ocupação de terras públicas na Asa Norte e zona central do Plano Piloto, em Brasília, Distrito Federal, entre os dias 2 de julho e 13 de agosto de 2009. Anteriormente, a partir de abril, já havia começado a mapear quais seriam os locais indicados para o trabalho de campo e no início de junho iniciei o levantamento in loco de cada um destes pontos. Assim, ao todo o processo de trabalho de campo compreendeu um intervalo de aproximadamente cinco meses.

\subsection{Caracterização do campo}

As entrevistas foram tomadas em quatro "acampamentos" dentre os vários visitados no Plano Piloto. Defino "acampamentos" entre aspas, sublinhando seu caráter de moradias provisórias, meras barracas de lona e papelão. Um desses acampamentos situava-se às margens da Via L3 Norte, próximo à área destinada à moradia de professores e alunos na Universidade de Brasília (UnB), Colina. Outro, às margens da Via N4 Norte, próximo ao hospital veterinário da UnB, nas cercanias do Centro 
Comunitário da Universidade. Também foram entrevistadas pessoas em um acampamento localizado pouco antes do final da Via L4 Norte, em frente à Estação Experimental de Biologia da UnB. O quarto acampamento está localizado em uma área de divisa entre SEN (Setor de Embaixadas Norte) e o SGO (Setor de Garagens e Oficinas Norte). Essa ocupação foi a maior encontrada e onde foi entrevistado o maior número de pessoas.

Além destes, uma entrevista foi feita com um morador de um acampamento (já extinto pelo poder público) nas adjacências da Rodoferroviária. Até o fim da elaboração do trabalho os acampamentos tiveram mudanças sucessivas de localização em decorrência de serem considerados não legítimos e inapropriados. Foram entrevistados, ainda, moradores de rua, que recentemente tinham sido destituídos de moradias, no citado acampamento próximo à Rodoferroviária.

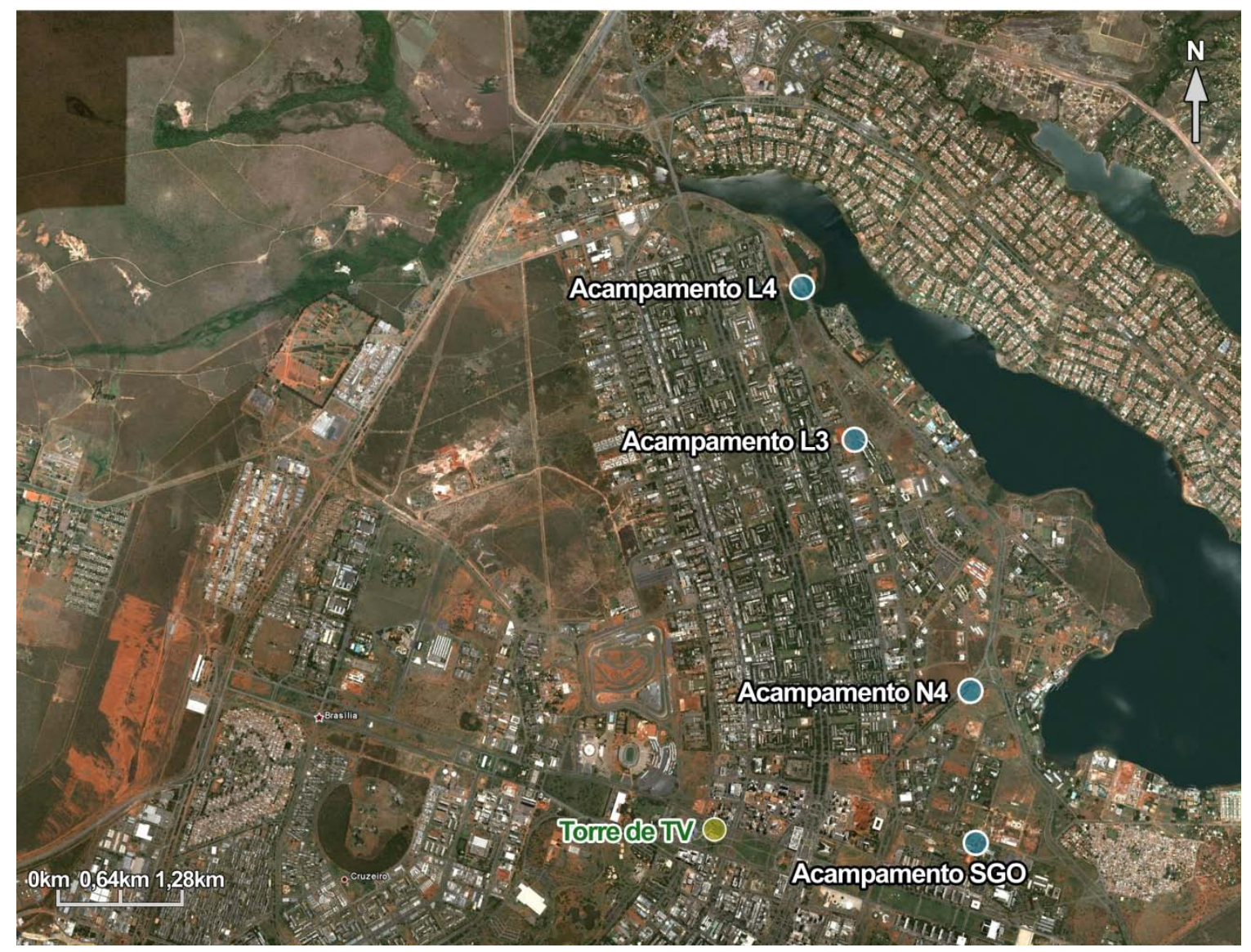

Figura 1 - Mapa da localização dos acampamentos

Fonte - Google Earth, 2009

\subsection{Caracterização dos entrevistados}


Como explicitado, a pesquisa foi empreendida com a população de rua, pessoas chamadas pela sociedade de "moradores de rua". Destes, foram selecionados 18 entrevistados em quatro "acampamentos", sendo que com 15 deles a entrevista foi totalmente concluída. As entrevistas não concluídas foram descartadas, não constando do anexo, no qual o material foi transcrito.

A maioria dos entrevistados é homem, trabalha como reciclador, está na faixa etária dos 30 anos e provém de áreas rurais da região Nordeste. Nos acampamentos encontrei também muitas crianças e mulheres, revelando que, embora provisórios, esses locais abrigam e reproduzem a vida familiar e comunitária.

Muitos dos entrevistados seguem um mesmo padrão: migraram há mais de vinte anos para o Distrito Federal. Apenas um deles estava aqui há apenas três meses, mas também tinha antecedentes de migração para outra área urbana, São Paulo. Muitos deles, inclusive, têm moradia legitimada em Brasilinha de Goiás, continuando, no entanto, a vir morar ou trabalhar na Capital por períodos relativamente longos (semanas, meses).

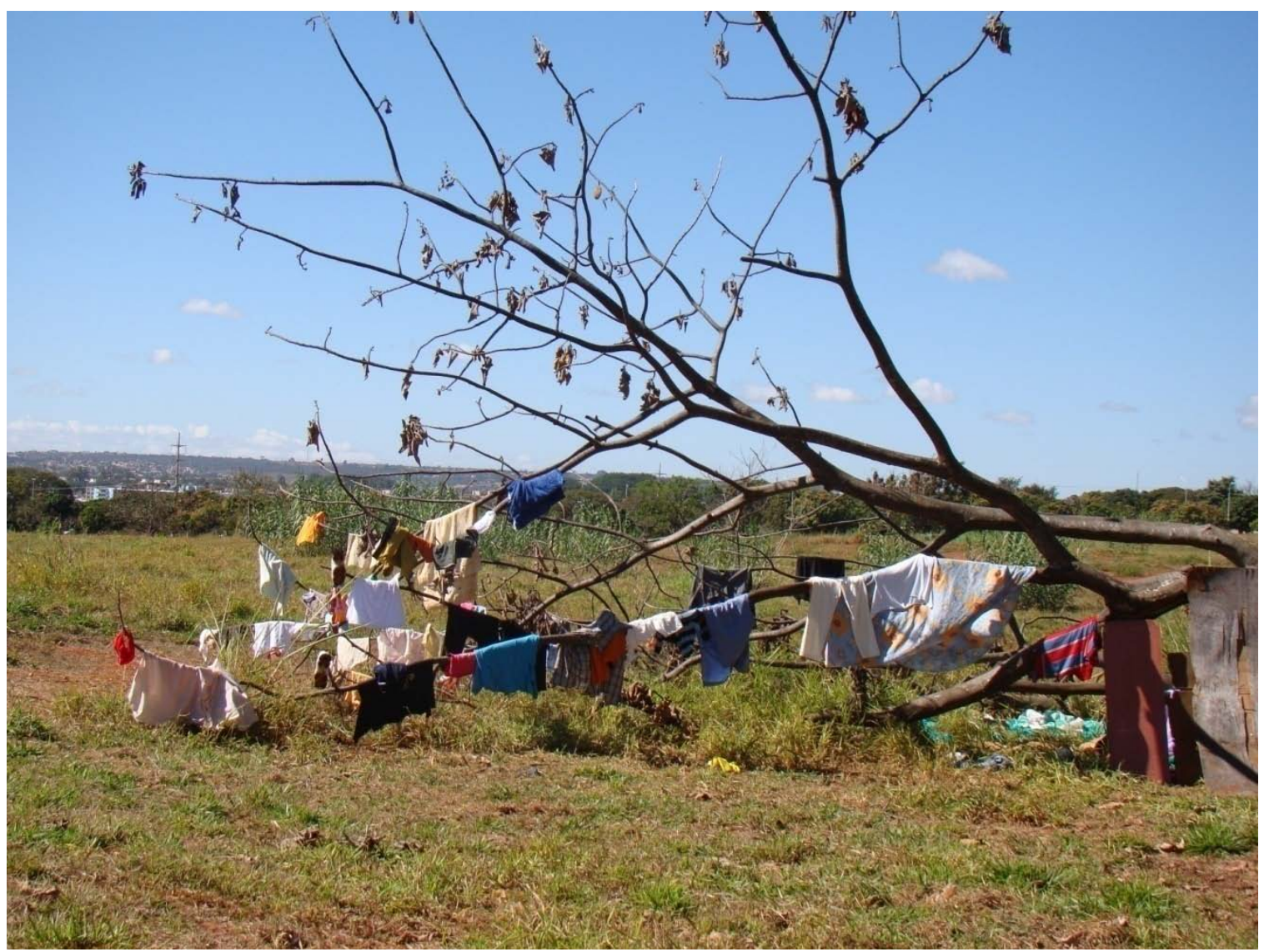

Figura 2 - Varal de roupas no acampamento localizado na Via L3 Norte Fonte - Bruno Rafael de Castro Guaitanele, 2009 


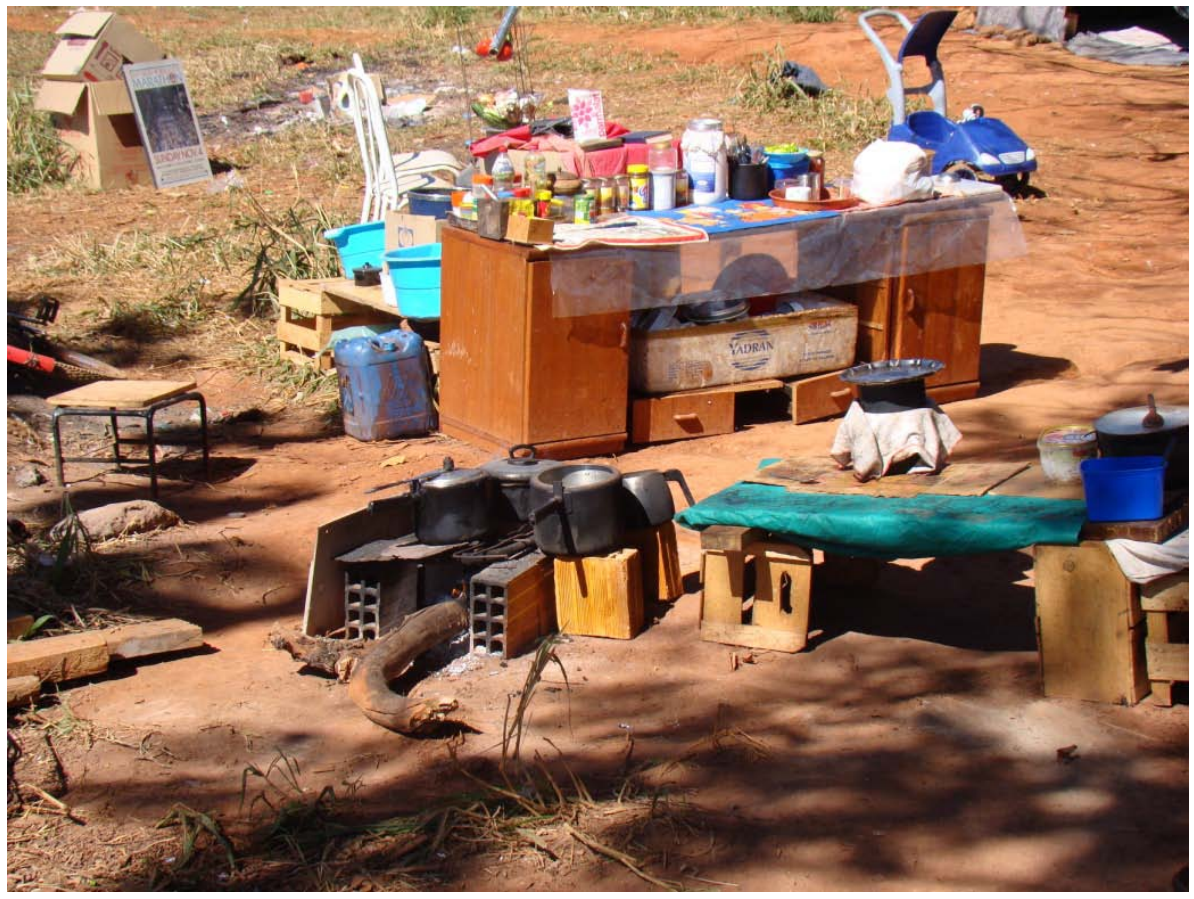

Figura 3 - Cozinha do acampamento localizado na Via L3 Norte Fonte - Bruno Rafael de Castro Guaitanele, 2009

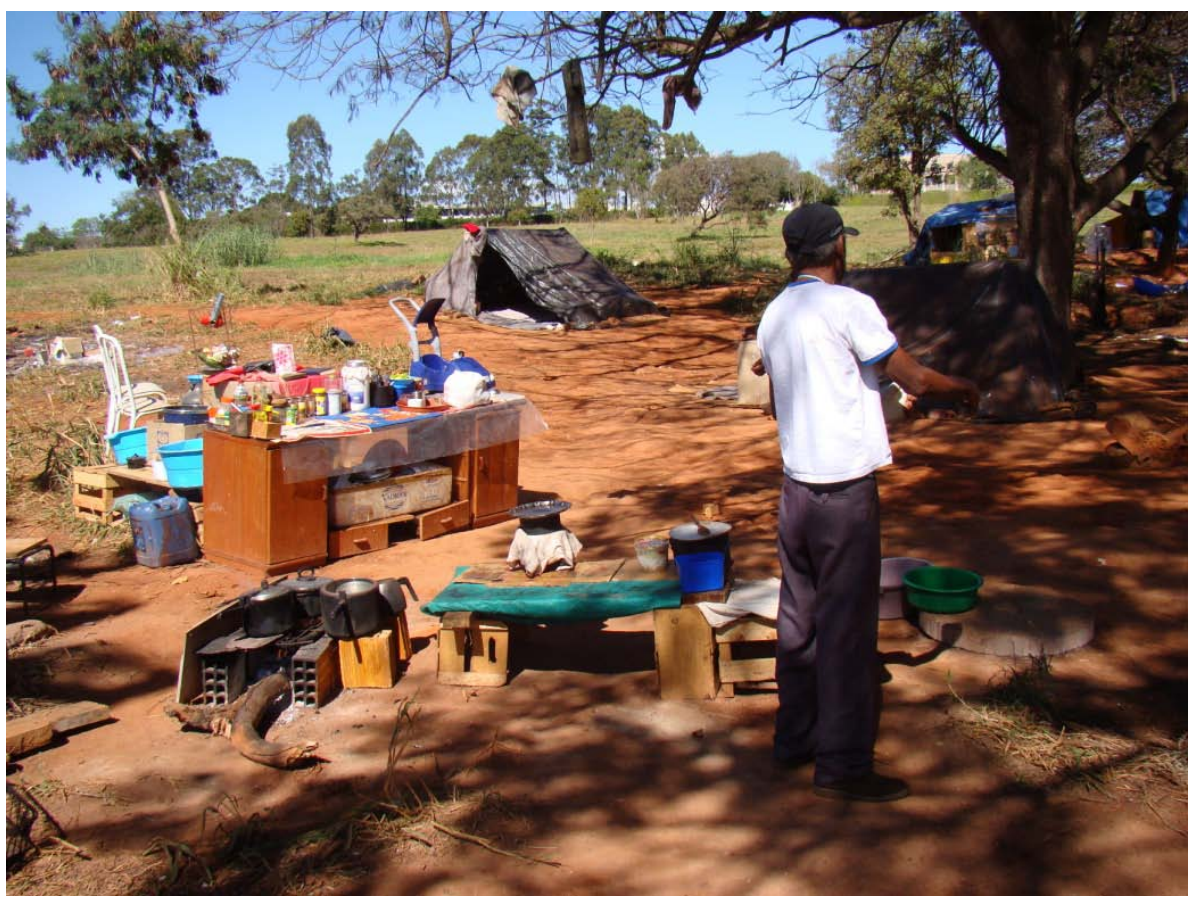

Figura 4 - Área comum no acampamento localizado na Via L3 Norte Fonte - Bruno Rafael de Castro Guaitanele, 2009 


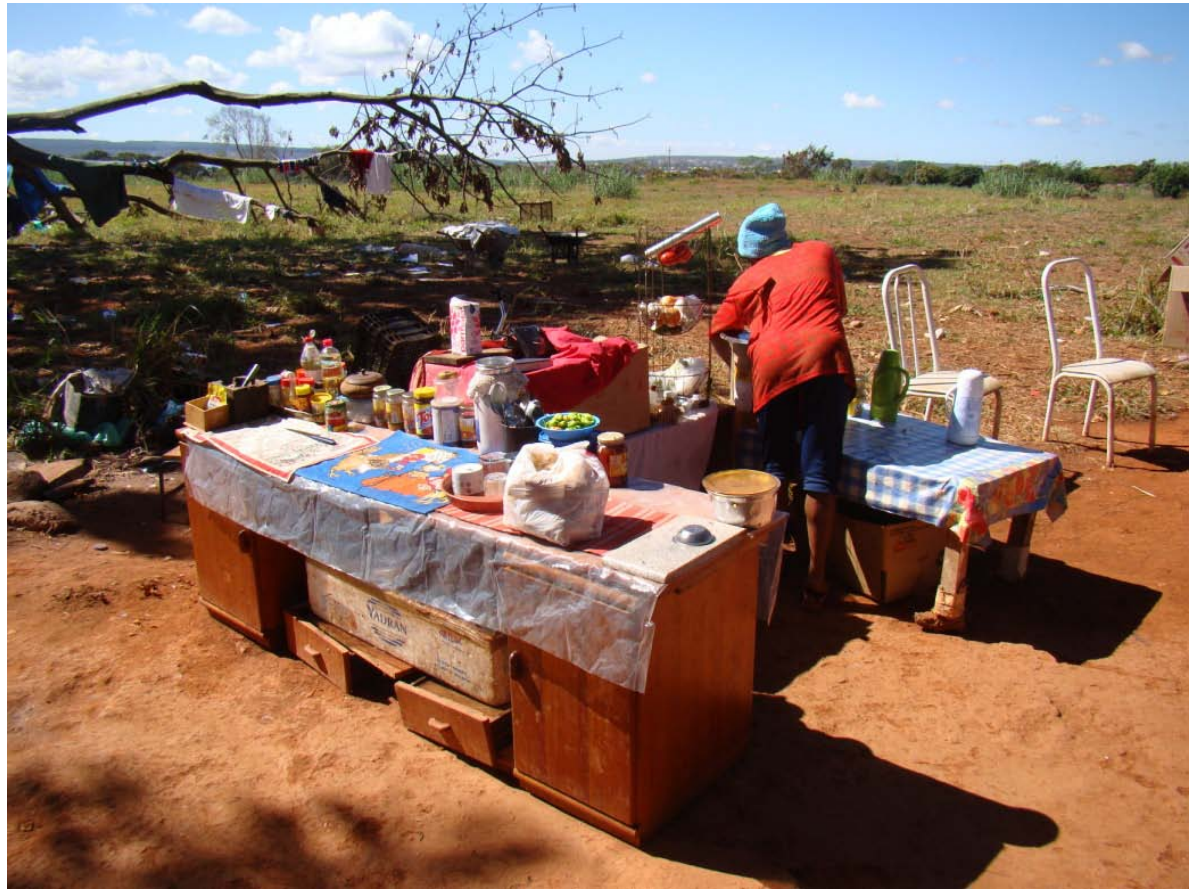

Figura 5 - Mulher preparando o almoço no acampamento localizado na Via L3 Norte Fonte - Bruno Rafael de Castro Guaitanele, 2009

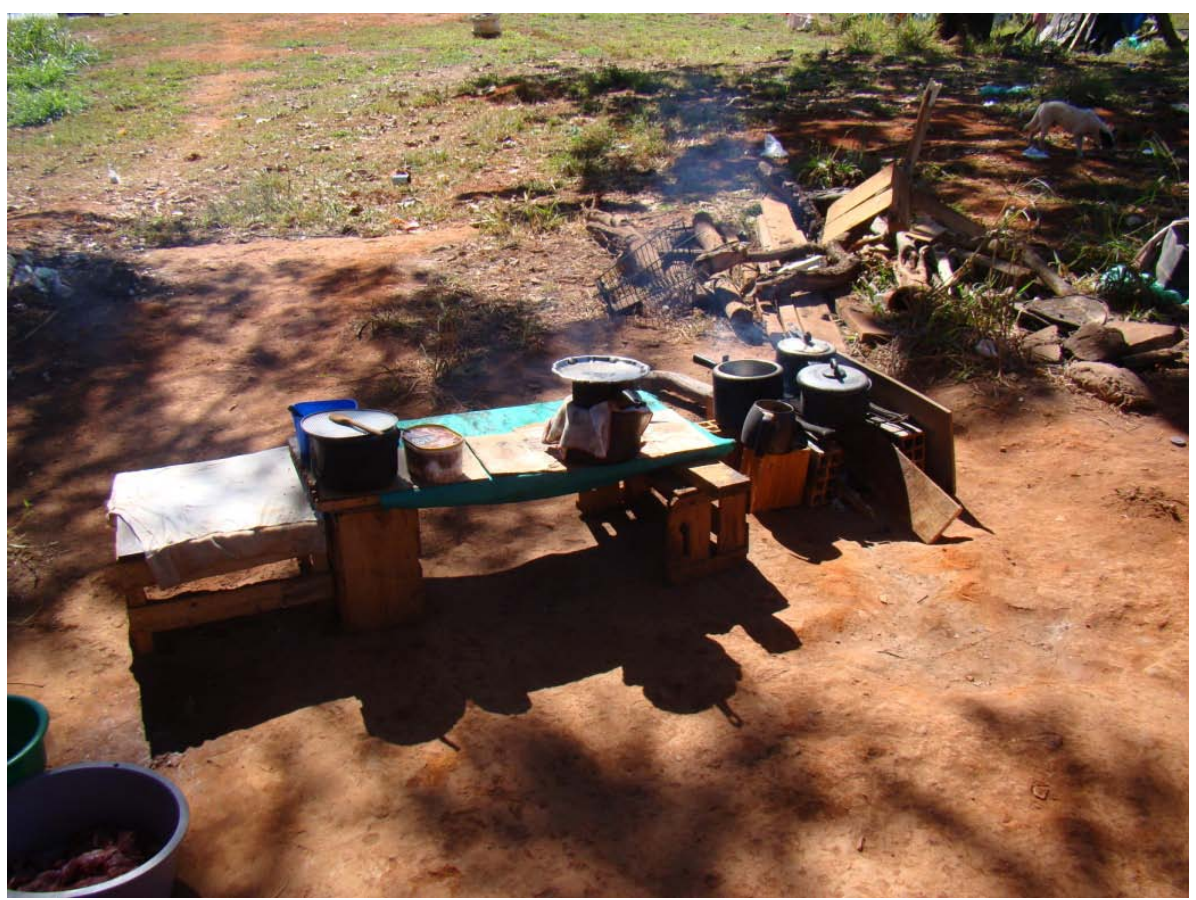

Figura 6 - Fogão improvisado no acampamento localizado na Via L3 Norte Fonte - Bruno Rafael de Castro Guaitanele, 2009 


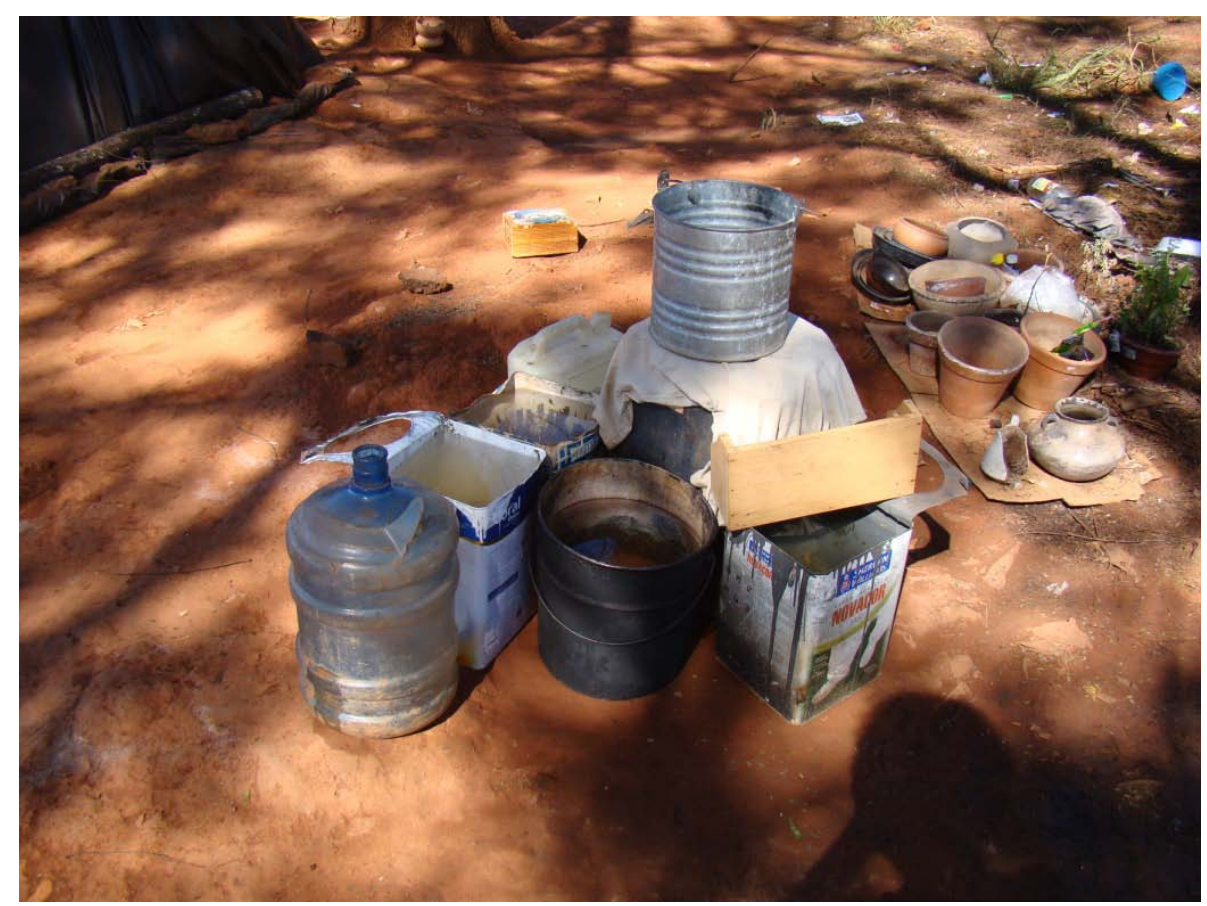

Figura 7 - Água utilizada no acampamento localizado na Via L3 Norte Fonte - Bruno Rafael de Castro Guaitanele, 2009 


\section{CAPÍTULO IV}

\section{DISCUSSÃO}

A tabulação e análise das entrevistas apontaram critérios para agrupar as falas, associando-as às seguintes categorias: cidade, sonhado e sofrido; lar; espaço produzido; zona rurbana e; relação entre habitantes da cidade, espaço legitimado pelo capital versus espaço negado. Cada uma dessas categorias será analisada a seguir, em tópicos orientados pelos conceitos definidos no marco teórico.

As falas mais representativas dos entrevistados, que reproduzem de forma mais contundente a sensação geral percebida sobre as categorias analíticas supracitadas, são reproduzidas na íntegra em vários pontos da discussão. No entanto, os entrevistados não são identificados por nome, sexo, idade e sim com os números aleatórios da ordem da gravação, apresentados, genericamente, pelo gênero masculino. Da mesma forma, o local onde cada entrevista foi tomada também não é identificado.

Essas medidas se devem ao fato de que, no momento em que cheguei aos acampamentos, estabeleci um acordo verbal com os entrevistados, pelo qual me comprometi a não identificá-los de forma alguma. Só diante desse acordo concordaram em conceder a entrevista. Outro motivo é que de nenhuma maneira gostaria de deixar margem para que eles possam ser prejudicados ou colocados em situação de maior vulnerabilidade do que a que já se encontram.

\subsection{Cidade: o sonhado e o sofrido}

De modo geral a falta de escola, atendimento médico, emprego e dinheiro são fatores que caracterizam seus locais de origem e que contribuíram para sua decisão "voluntária" de migrar. Todos compartilharam essas difíceis condições de vida nos rincões de pobreza no qual nasceram: "trabalhava na roça, minha mãe tem roça essas coisas tudo, mas a gente trabalhava na roça da pessoa [proprietário da terra]" (Entrevistado 9). Relatam que "lá onde nóis tava morando não tinha trabalho" (Entrevistado 18); "Porque lá onde eu morava o lugar é muito devagar, não tem trabalho [...] Tive que correr, correr" (Entrevistado 10). 
A falta de dinheiro constante nessas localidades revela-se na fala dos entrevistados de maneira contundente: "A diária lá era na época sete reais" (Entrevistado 4). Outro entrevistado quando perguntado sobre o motivo de achar a vida na cidade mais fácil do que na roça responde que é o dinheiro, apontado por muitos como um fator crucial para a migração para a cidade, chegando ao ponto paradoxal, dadas suas condições de vida, de considerarem que o mais fácil na cidade é "dinheiro" (Entrevistado 9). Além de agora conseguirem ter mais acesso ao dinheiro, mesmo que ainda não seja muito, também o percebem com mais frequência do que antes. $O$ dinheiro está materializado nos carros novos que vêem nas ruas, pessoas bem vestidas, prédios grandes, doações generosas.

Nesses contextos de penúria de seus locais de origem as representações da cidade grande, do desenvolvimento e do progresso, atuam como forças propulsoras, impulsionando ainda mais o desejo de migração: "[...] Na verdade vim para Brasília pelo fato de que realmente na cidade grande e desenvolvida que é aqui mesmo tem como a gente sobreviver" (Entrevistado 4). Para eles, a cidade representa e é confundida com tudo aquilo que não encontravam em seus locais de origem, aquilo pelo que reuniram coragem para lutar, deixando para trás toda uma vida: "Em procura de tratamento médico e trabalho. Porque lá nem médico não tinha" (Entrevistado 18); "[...] Lá era difícil d'eu estudar porque morávamos no interior [...] tocava lavoura na roça e passava mais tempo na roça, não tinha colégio perto" (Entrevistado 2); "[...] Lá trabalhava na chibanca, trabalhava no açude" (Entrevistado 7). Apesar de vários depoimentos enfatizarem o sonhado em relação à vida na cidade ao menos um reforça o sofrido no local de origem, como um fator maior que a expectativa de melhora em uma vida urbana: "Não imaginei nada. Eu acho que só quis sair de lá" (Entrevistado 9).

No entanto, ao chegar ao destino percebem que é "muito diferente do que imaginei. Mesma coisa quando fui para São Paulo. Achava que era uma coisa diferente, cheguei lá sofri pra caralho [...] voltei para Bahia e agora to aqui [...] é financeiro, o cara pensa que é uma coisa e se torna outra mais difícil" ( Entrevistado 11). Porém, as representações de cidade ainda atuam sobre essas pessoas, que permanecem envoltas pelos sonhos e imaginário de antes, mesmo quando acham que sua vida não se transformou como imaginado ou se constatam que "só fez foi piorar" (Entrevistado 5) com a saída da roça para cidade: "Achei que aqui era bom e dava 
pra fazer as coisas mais fáceis" (Entrevistado 5); "Imaginava que teria um bom emprego, que a vida mudaria um pouco" (Entrevistado 2).

A permanência desse imaginário sobre a cidade talvez se deva ao fato de nas metrópoles poderem vislumbrar de perto tudo que poderiam ter sido e tido ou até, tudo que um dia terão se trabalharem, se quiserem de verdade: "Oh, muito bom. Brasília é o país melhor que a gente tem no nosso país é Brasília, tudo é mais fácil" (Entrevistado 9).

Um entrevistado congrega várias representações de cidade, juntando todos os fatores citados, materiais e imateriais, atribuídos ao espaço urbano: "É tudo, como eu acabei de falar. É tudo, né?! Porque todo mundo precisa de luz, precisa de água, precisa de paz, precisa de trabalho e tudo, né?! De respeito, honestidade. Pra mim é tudo" (Entrevistado 6). Nessa representação percebemos tanto os aspectos materiais, água, luz como os imateriais, respeito, honestidade. Para os moradores dessas localidades cidade é sinônimo de espaço urbano: infraestrutura, possibilidade de emprego, escola, saúde e os demais atributos associados a uma vida digna.

Apesar desses fatores não terem se consubstanciado como realidade para essas pessoas, de forma plena, elas ainda enxergam cidade como o lócus dessas estruturas, porque mesmo que não tenham conseguido melhores condições de vida, ao menos agora, estão mais perto, mesmo que só fisicamente, desses serviços. A realidade que outrora só imaginavam pode ser observada na vida dos outros moradores da cidade. Prédios de várias escolas existem, hospitais existem, lojas, serviços. Está tudo aqui na frente de nossos olhos: material e concreto.

Quando perguntados dos motivos de terem se estabelecido nesses pedaços de solo negados, nesses "acampamentos" de plástico em terras públicas, percebe-se que sempre acham razões para culpabilizar a si mesmos. A imagem da cidade como local dos sonhos, luzes e serviços continua intacta: "A cidade é generosa, as pessoas são legais" (Entrevistado 6). A cidade tem tudo e o não acesso aos serviços, a melhores condições de vida, é atribuído, unicamente, aos próprios sujeitos: são eles que fracassaram. Corrobora esse sentimento de culpa o fato de serem marginalizados pelas pessoas dos espaços legitimados pelo capital, que os 
evitam, têm medo ou simulam indiferença. Diante de tais respostas é normal que pensem que a culpa é só deles, eles são errados.

Exemplifica esse sentimento, o trecho a seguir, da fala de um entrevistado ao responder se essas luzes, respeito, honestidade, água, se esse tudo da cidade, era fornecido para todos os habitantes: "Dá! Dá pra todo mundo. Mas tem muita gente que não quer, mas que dá, dá. Mas tem gente que não aproveita. Mas tem gente que fica preferindo ficar bebendo pinga do que tá trabalhando [...] Porque aqui em Brasília tem muita gente que ajuda na educação, em tudo, mas tem gente que não quer e fica na gandaia" (Entrevistado 6). Apesar das evidências alimentam a certeza de que seu esforço individual será sempre recompensado e que se de fato você trabalhar muito terá um futuro promissor: "Eu mesmo agora, quem diria que alguém pelo menos parasse o carro e dissesse: 'Ói, tem um quintal lá em casa para capinar. Vamos lá capinar?'. Eu iria. 'Tem um caminhão ali para descarregar', eu iria. E mesmo sem ter condição de carregar tanto peso, como eu, que tenho uma cirurgia aqui que é do pé da barriga ao estômago" (Entrevistado 4).

Essa crença no esforço pessoal como única condição para a superação das adversidades sociais parece ser amparada pelo simples fato da pessoa poder trabalhar: "A vida é um pouco difícil, mas não me obriga aí, a eu virar praticamente um bandido" (Entrevistado 4). As dificuldades enfrentadas também não impedem o deslumbramento com as pequenas conquistas, seja da autonomia de trabalho ou relativas às suas parcas posses, que garantem o pão de cada dia: "Aqui ó, olha meu carrinho, é meu carrinho esse aqui. Sabe quanto eu ganho no máximo em quinze dias?! Trezentos conto, na Bahia ganho cem, cinquenta reais no máximo [...] [Lá] o custo de vida é difícil" (Entrevistado 9).

No trecho acima fica nítido também outro aspecto, relacionado à polissemia que pode ser atribuída a algumas palavras, como, por exemplo, a ideia de "custo de vida". Enquanto para os moradores do espaço legitimado pelo capital, os escolarizados e monetarizados, essa expressão representa quanto se gasta para viver ou quanto se tem para consumir, para estes moradores do espaço negado custo de vida refere-se ao dispêndio de esforço, à energia e trabalho necessários para conseguir sobreviver. Essas duas perspectivas desvelam distintos olhares, daqueles que vivem e dos que apenas sobrevivem em nossa sociedade. 
Despontam nos discursos também as noções de autonomia e liberdade. Ter meios para garantir o próprio sustento (ainda que de forma precária) se materializa no carrinho de reciclagem e, para aqueles que também têm outras atividades, o fato de não ter patrão e não prestar contas a ninguém, mesmo que isso implique em insegurança e ausência de direitos trabalhistas. A afirmação a seguir aponta para a importância que conferem a esses valores: "Aqui eu não trabalho pra ninguém não! Trabalho por minha conta, sou pescador. Lá eu pescava, mas não dava para ganhar o dinheiro que ganho aqui não" (Entrevistado 12).

Associada às ideias de liberdade e autonomia pode-se perceber nas entrevistas a palavra "conquista": "É, a gente aqui passa uma semana trabalhando para conquistar cinquenta reais, sessenta reais. [Mas] Não chega nem a trezentos conto por mês" (Entrevistado 4). Bastante citada, seja quando se referem à procura de alimentos no lixo, de materiais para reciclar, de local para o acampamento, o uso dessa palavra denota que suas vidas são uma constante batalha, já que o sentido da palavra conquistar é relacionado ao êxito em conseguir alguma coisa bastante difícil, como ganhar uma guerra. Reforçando essa impressão um entrevistado colocou: "Tamo aí guerreando com o mundo, o mundo guerreando com nóis" (Entrevistado 6).

Quando perguntados sobre a possibilidade de voltarem a suas cidades de origem, todos relataram que têm tal desejo, mas que só voltam se conseguirem alguma forma de sobreviver lá, como aposentadoria rural, por exemplo, ou se puderem juntar dinheiro suficiente para abrir seu próprio negócio: "Só vou voltar pra minha cidade se Deus permitisse que eu tivesse uma boa condição de chegar lá e levantar um comércio e esse comércio que eu levantasse de preferência seria um comércio de comida, que é uma coisa que nunca estraga e você nunca passa fome [...] Aí seria bom assim" (Entrevistado 4); "Atualmente estou aqui [acampamento]. Mas eu trabalhava em uma fazenda, agora estou vendo os documentos para me aposentar. Só esperando o CPF chegar" (Entrevistado 14).

Um entrevistado mais velho, de 80 anos, que já perdeu o orgulho frente aos duros entraves da vida, chegou a chorar quando falou de sua vontade de voltar ao lugar onde nasceu: "Daqui é capaz que eu vou voltar pra trás [...] Quero voltar para lá, não 
quero ficar aqui. Ficar lá do que aqui. Lá minha irmã cuida de mim" (Entrevistado 10).

\subsection{Lar}

As pessoas entrevistadas têm o solo público como local de moradia; a rua se transformou em sua casa a partir do momento que se apropriaram desse espaço e o transformaram em lar. As "paredes" de lona e papelão seccionam o público e o privado e delimitam a apropriação de parcelas diminutas do solo. Embora para aqueles que habitam em construções de alvenaria tais "casas" não sejam mais que arremedos, um dos entrevistados negou enfaticamente essa perspectiva.

O entrevistado 18 foi encontrado na rua. Paramos o carro e perguntamos se podíamos entrevistá-lo. Ele estava puxando um carrinho cheio de papelão com um cachorrinho acompanhando. A entrevista foi a mais rápida porque estávamos em meio ao tráfego e ele estava trabalhando, catando papelão, mas foi uma entrevista que desvelou uma perspectiva significativa para analisar o ponto em questão. Quando perguntado sobre onde mora disse que havia morado na invasão perto da Rodoferroviária, mas depois que retiraram os barracos, as lonas e papelões, assim como suas coisas íntimas, ele passou a morar na rua, ainda que fisicamente ocupasse o mesmo espaço. Ou seja, enquanto para esse brasileiro aquele espaço cercado por plástico era sua casa ${ }^{13}$, para os demais transeuntes que por ali passavam bem como para o poder público, ele era um morador de rua. $O$ espaço produzido e apropriado se torna diferente dos outros e se começa a ter por aquela localidade um sentimento de pertencimento, associado às representações de casa e lar.

Se para o transeunte a situação dessas pessoas inspira medo ou indiferença para o Estado implica no dever de retirar tal pessoa dessa condição e colocá-la em outro

\footnotetext{
${ }^{13}$ Armand Frémont (1980, p. 130) ao tratar da relação do homem-habitante com o espaço habitado tece considerações relevantes sobre o enraizamento no espaço e a importância da casa para o homem. Mesmo que seja só um esboço de casa precário, sem relação duradoura com o solo, criam uma sensação de agrupamento, tranquilidade e abrigo. A relação íntima do homem com seu espaço habitado é descrita pelo mesmo autor da seguinte forma: "É para os seus habitantes, por si só, o universo da intimidade, da família, da mãe... descansa e tranquiliza. É abrigo e lar [...]. Inscreve-se num espaço organizado para a vida, é carregado de todos os valores quase míticos que associam à terra, à mãe, à reprodução dos seres. O homem liga-se-lhe como a uma parcela de si próprio, mais preciosa ainda do que a própria vida. [...] a casa participa intimamente na negação do tempo e da morte. Dá a segurança e a satisfação do enraizamento".
} 
lugar, do qual possa se apropriar de maneira formal e legítima. Cabe ressaltar, entretanto, que há muitos casos nos quais não existe a possibilidade de legitimar a ocupação do espaço por falta desse capital legitimador, deixando essas pessoas sempre a margem do direito à cidade: "É assim, invasão é assim, a gente sai de uma invasão e vai para outra e vai para outra porque não tem lugar pra gente ficar. Cruzeiro, morei no Cruzeiro, atrás da Ceasa, ali na Parmalat [...]" (Entrevistado 9).

Não obstante considerarem as barracas precárias dos "acampamentos" como casa, permanece o sonho de um dia poder ter acesso e recursos para adquirir uma moradia convencional, no espaço legitimado pelo capital: "Eu mesmo queria estar morando em um apartamento desse ou talvez até mesmo em uma casa no chão mesmo, mas que fosse aqui mesmo no DF, que eu pudesse trabalhar levar reciclagem para lá e vender e ter minha vida digna de cidadão [...] Mas para falar a verdade, não é como a gente quer, pra falar a verdade" (Entrevistado 4).

\subsection{Espaço produzido}

Os "acampamentos" de plástico são constituídos por moradias precárias construídas pelos próprios moradores com papelões, plásticos, papel. Nesses acampamentos havia muito lixo pelo chão no qual as crianças brincavam: "[...] Tá sendo essa aventura pra nóis, né, que nois aqui dorme de madrugada, os meninos brincam até meia noite [...] Aí, amanhece o dia matando rato e por aí se vai. Pra eles [crianças] é o quê? Uma aventura, né? E pra nóis também" (Entrevistado 6).

A luz, quando tem, é a do poste público e a água é carregada de outros lugares em latões na cabeça ou nos carrinhos de madeira, os mesmos que usam para levar o material que coletam para reciclagem. Os barracos parecem ser bem pequenos, como barracas de acampamento, dando a ideia de que são utilizados principalmente como dormitório. Em cada um desses barracos geralmente dormem o pai, a mãe e os filhos: "Realmente, nesse barraquinho aqui mora eu, ela e nossos meninos" (Entrevistado 4); "[...] minha cama é aquela ali, uns papelões, plásticos e um edredon" (Entrevistado 15).

Em muitos deles os fogões são comunitários, improvisados com pedras, feitos no chão em lugar comum e mais ou menos equidistante das moradias. Sejam 
comunitários ou individuais, o local onde são instalados esses fogões lembra cozinhas porque além do fogão, outros utensílios, como panelas e pratos, são arranjados sobre paus e pedras, simulando estantes ou armários. Nessas áreas externas, latas de tinta ou de outros tipos, são usadas como bancos.

O alimento é conseguido diariamente. Comprado, se conseguem trocar bastante material de reciclagem ou algum outro trabalho. Ganhado por outros moradores tanto dos espaços negados quanto dos legitimados pelo capital ou achado no lixo: "A gente não passa tão mal porque a lixeira, ela ajuda a gente bastante [...] porque na lixeira conquisto muitas coisas: feijão, arroz. Na lixeira muitas coisas a gente conquista. Tipo mesmo, carne. A gente não come carne. A gente come muxiba, porque tem os açougues, que as pessoas dá valor a gente. Eles dão valor mesmo. Eles ajudam." (Entrevistado 4).

Como trabalham como recicladores há sempre sacos com o material coletado próximos às barracas. Os mais afortunados também têm um carrinho de madeira, parado ao lado das barracas. Usado para o transporte do material coletado é puxado por eles mesmos, já que com a proibição de circulação de carroças esses veículos têm sido recolhidos, segundo informam: "Olha, eu, teve um tempo atrás que eu tinha uma carroça, sim. Eu trabalhava bastante com essa carroça, fazia duas viagens durante o dia para não cansar o cavalo, não maltratar ele. Mas o Arruda mesmo levantou uma polêmica de tomar carroça e cavalo. Tomaram uma carroça minha e eu passei quase dois meses trabalhando, pagando ela, trabalhava direto para pagar ela [...] Tomou minha carroça e nunca mais devolveu" (Entrevistado 4).

Um aspecto que chama atenção é que todos se caracterizam como "recicladores". Chamar-se a si mesmos de recicladores não é apenas definir o nome da própria atividade de trabalho, mas, principalmente, é definir-se a si mesmo enquanto pessoa na sociedade, já que no mundo contemporâneo, especialmente nas áreas urbanas, as pessoas "são" aquilo que fazem. Por isso a importância da pergunta: O que você faz? As pessoas se definem socialmente pela profissão. Assim, ser reciclador é ser alguma coisa: "Não, emprego mesmo assim nunca tive não. Meu emprego sempre desde que cheguei em Brasília até a data de hoje foi de reciclador, quando tinha carroça retirava o entulho de muitas pessoas" (Entrevistado 4). Ser reciclador não é 
ser desempregado, vagabundo, pedinte, indigente, mendigo. Significa que a pessoa está inserida na escala social, mesmo que em baixa posição.

Além do mais, a identidade de reciclador tem um lado positivo, que vem sendo cada vez mais valorizado socialmente, pois está associada à transformação do lixo, do material descartado, tão abundante e problemático na sociedade de consumo: "Esse lado mesmo de trabalhar para não ficar só no barraco esperando, dá pra ver que se torna isso aqui: que é a reciclagem e serve mais para as pessoas que têm condição porque, queira ou não queira, a reciclagem é válida" (Entrevistado 4).

Reciclador não é lixeiro, que apenas transporta o dejeto. Não fosse o fato deste último ter emprego fixo, com carteira assinada, estaria abaixo do primeiro na escala social, pois ao menos na dimensão do imaginário o reciclador ajuda a transformar o lixo em coisa útil. No entanto, essa identidade positiva restringe-se à dimensão simbólica, já que na prática quem a desempenha não é reconhecido e nem legalizado na sua atividade e moradia.

O trecho a seguir reforça a afirmação de que a identidade social (e pessoal) é construída pelo trabalho: "Mas as pessoas chegam, acusam, fala: 'Ah, você não vale nada, num sei o que lá [...]' Já outros dizem: 'Não, pelo menos você trabalha, numa fica só esperando, esperando" (Entrevistado 4). Quem não trabalha "não vale nada" (porque não ganha nada), mas se trabalha, ainda que numa atividade pouco reconhecida e instável, passa a ser alguém que pode ser respeitado: "Porque antigamente, quando eu era gente, podia trabalhar pegar no cabo de chibanca, de foice, roçado de tudo e hoje, não posso, já tô veia, tenho braço doente, mas se eu me aposentar eu vou embora véi" (Entrevistado 7).

Inicialmente os espaços negados apareciam aos meus olhos como retalhos pela cidade, mas não demorou muito tempo para perceber que, para os entrevistados não é assim, existe uma conexão, um conhecimento do "mundo de plástico", mesmo quando os acampamentos estão localizados em locais mais afastados e sem acesso a pistas de asfalto. Mesmo em áreas distantes (há horas de caminhada) conhecem os outros "acampamentos" e, com frequência, já moraram em mais de um deles, tendo parentes que ainda vivem nessas localidades. 
Quando perguntado dos outros acampamentos os entrevistados conversam entre si, lembram quem ainda mora em certos acampamentos, perguntam uns aos outros sobre os parentes e amigos que habitam neles, e contam sobre os "acampamentos" retirados pela fiscalização. A informação da localidade de vários acampamentos, mesmo os que não me aventurei a entrar, foi fornecida pelos próprios moradores dos espaços negados: "[...] Minha família todinha vevi aqui [em acampamentos]. Tem uma que mora na Vila Planalto [...] tem uma que mora na Vila [...] Não, duas. Três que mora no Valparaíso e já tem uma que vevi em Brasilinha e assim vai indo" (Entrevistado 6).

As notícias sobre os acampamentos retirados pelo governo circulam rápido entre eles, de um acampamento para o outro, o que alimenta o medo, que impede até mesmo de sair para trabalhar, como muitos deles relataram: "Só que o medo da Subssolo chegar e levar tudo [...] Aqui a gente trabalha com medo, veve com medo. Agora, com medo mesmo, só do governo" (Entrevistado 4); "Liguei um tempo passado [para os familiares que deixou na Bahia], mas o contato que eu tinha a Subsolo [Sudesa] quando vem leva tudo. Quando ela vem a gente tem que pegar esse carrinho e sair em alta velocidade e esconder ele para que ela não veja, porque se ver leva. A reciclagem, já tiveram aqui duas vezes, não levaram porque eu pedi na humildade" (Entrevistado 4).

Esse temor parece justificado, pois, como contam, as vistorias dos fiscais da Sudesa não se limitam a desalojá-los, mas também a destituí-los dos parcos bens que conseguiram: "Levam, levam tudo. Essa semana levaram tudo [até o] colchão da minha sogra" (Entrevistado 9). Essa violência indiscriminada só dificulta ainda mais seu acesso às condições de cidadania, pois não é raro que nessas vistorias sejam confiscados também documentos pessoais, telefones de contatos, fotografias, comida, roupas e até uniformes escolares, aumentando o medo frequente de perder tudo que têm: "Mas como que procura emprego se nóis aveve sem documento?" (Entrevistado 6).

A instabilidade desses espaços, devido às vistorias de fiscais da Sudesa, faz com que tenham que se mudar constantemente. Na verdade, por seus relatos, suas vidas assemelham-se as de tribos nômades fugitivas, que procuram escapar de seus caçadores embrenhando-se no Cerrado: "Aqui em Brasília eu morei no SIA, morei na 
28 no setor de embaixadas, morei no Cruzeiro, na invasão do Cruzeiro" (Entrevistado 9); "Oh, minha filha [...] eu morei em vários cantos. Santa Maria, Valparaíso, Recanto das Emas, Brasilinha, São Sebastião [...]" (Entrevistado 7). A maioria dos entrevistados conta que já viveu em, no mínimo, três localidades, sendo que muitos já chegaram a morar no dobro dessa quantidade de lugares.

Apesar de grande parte dos entrevistados viverem no Distrito Federal e no entorno a mais de 20 anos, mudando constantemente de local de moradia e, portanto, transitando e conhecendo áreas distintas como Taguatinga, Ceilândia, Gama, Santa Maria, Sobradinho, Guará, SIA, Núcleo Bandeirante, Valparaíso, Cruzeiro, Brazlândia, Jardim Ingá, não sabem precisar a dimensão exata ou aproximada do Distrito Federal. Um deles chegando, por exemplo, quase a equiparar Remanso, no interior da Bahia, que em 2006 contava com 37.639 habitantes, distribuídos em $4.694 \mathrm{Km}^{2}$ com Brasília que, no ano 2000, tinha 2.051.146 habitantes em seus $5.789,16 \mathrm{Km}^{2}$. Essa noção de densidade demográfica parecer ser construída apenas a partir de sua vivência cotidiana, percorrendo a pé as ruas da cidade a procura de trabalho (material reciclável para venda) ou local para acampar (moradia), já que a maioria não tem acesso à informação e não frequentou a escola.

\subsection{Zona rurbana}

A zona rurbana, constituída pelos diversos "acampamentos" de plástico distribuídos por toda a cidade, representa também os "lugares do encontro simbólico entre dois mundos que já se interpenetravam", tal como Rodrigues define as portas das cidades medievais. É onde o meio urbano se mistura ao rural, onde ocorre o encontro de expectativa e frustrações, comuns a esses migrantes (também de origens comuns).

Entre o mundo feito de asfalto e edificações vivem pessoas que se identificam como "compadres, cumades", que dividem costumes e modos de vida ainda preservados. Nos "acampamentos" de plástico se distribuem famílias. Mas não é só o laço de parentesco que os une, é também a situação, o fato de participarem juntos da construção desse mundo paralelo à cidade. Exceto um entrevistado, todos os outros mostraram um sentimento de apoio uns aos outros, grupos que andavam e se 
estabeleciam em "acampamentos" sempre juntos. Alimentando um sentimento de solidariedade.

Quando perguntado para um senhor sobre as crianças que brincavam no acampamento, se eram seus netos, respondeu: "Não, só esse aí. Aquele outro a mãe abandonou e sumiu. Sei pra onde foi não. E como ela morava com meu filho, aí pra não ficar jogado aí pegamos os dois" (Entrevistado 3). Em alguns acampamentos não só a comida é compartilhada, mas também os netos, pessoas, responsabilidades. É necessária uma parceria para morar e sobreviver nos espaços negados porque estão sempre suscetíveis à retirada pelas autoridades. Assim, convivendo em comunidades, protegem-se uns aos outros e têm mais força para resistir e defenderem seu espaço e suas vidas.

Quatro entrevistados relataram ter nascido em cidades grandes e onze deles em cidades pequenas. Embora aleguem origem urbana, mesmo que em cidades pequenas, todos relatam ter trabalhado no campo, "na roça" ou "na chibanca", evidenciando a origem ou o padrão de socialização rural: "Trabalhava na roça. Plantava feijão, rançava feijão, batia feijão" (Entrevistado 4); "Trabalho braçal, mexendo com gado, lavoura" (Entrevistado 14). Até quem diz que viveu em uma capital, Belo Horizonte, conta que passava a maior parte do tempo trabalhando na lavoura: "Nós morávamos em Belo Horizonte, mas a gente tocava lavoura na roça e passava mais tempo na roça. Não tinha colégio perto" (Entrevistado 2).

\subsection{Relação entre habitantes da cidade: espaço legitimado pelo capital versus espaço negado}

A situação desfavorável a qual estão submetidos os brasileiros que vivem no espaço negado propicia o surgimento de conflitos e confrontos constantes tanto com os poderes públicos quanto com a sociedade civil. A desconfiança com que são percebidos e a aura de perigo que os envolve, por não disporem de educação formal, bens ou recursos econômicos fortalece uma barreira de preconceito e discriminação difícil de superar.

As circunstâncias adversas de suas vidas, somadas à discriminação e preconceito, os tornam alvo fácil, muito suscetíveis a atos de violência. Consoante às estatísticas 
de mortalidade por sexo e faixa etária, que apontam que os homens, negros e jovens, estão mais propensos a episódios de violência e morte prematura ${ }^{14}$, grande parte dos entrevistados relatou ter perdido filhos adultos, vitimados por assassinatos: "Chegou duas horas da manhã, ele estava dormindo. Abriu a porta, doidão de droga, pegou deu um tiro. Sempre meus filhos morrem com só um tiro no peito, no peito esquerdo dele" (Entrevistado 3); "Nove, eram nove, mas Deus levou dois" ( Entrevistado 7).

Não bastassem tais circunstâncias que enfrentam no cotidiano, os próprios poderes públicos, ciosos dos direitos dos cidadãos que habitam o espaço legitimado pelo capital e pagam impostos, incitam a intolerância contra eles, estimulando a população a denunciar invasões, como forma de assegurar o patrimônio público, tal como no site da Terracap (2009): "Denuncie os invasores. Ligue 156. A sua denúncia será recebida pela Ouvidoria do GDF e encaminhada à Comissão de Fiscalização e Combate de Invasões. Com a sua ajuda, vamos acabar com as invasões". Ainda que tal providência possa ser considerada justa e legítima, especialmente quando se volta aos muitos grileiros de terra que impunemente loteiam áreas nobres do Distrito Federal, faz recrudescer também a hostilidade contra esses ocupantes de terras públicas, sem posses ou armas para defenderemse, que, ao contrário dos grandes grileiros estão nesta situação por falta de opção e não por escolha.

Um dos entrevistados chegou a descrever uma situação conflituosa com um habitante dos espaços legitimados pelo capital, na qual fica evidente sua sensação de ter sido desprezado e desrespeitado em função de não ter escolaridade e ser "morador do Cerrado": "Aquele de camisa branca [morador do prédio na frente do acampamento] falou que fui eu que tinha tocado fogo ali, sabendo ele que é nossa

14 "A expectativa de vida é influenciada pelo pertencimento a um grupo de cor/raça e ao sexo. As mulheres vivem mais e os negros, menos. Em 2006, enquanto 9,3\% das mulheres negras tinham 60 anos ou mais de idade, entre as brancas essa proporção era de 12,5\%. Em 1993 tinha-se 7,3\% e $9,4 \%$, respectivamente, o que indica que, apesar de a expectativa de vida da população ter aumentado, tendo crescido a proporção de idosos nos diferentes grupos populacionais, as desigualdades entre os grupos permanecem. Esta diferença da expectativa de vida pode ser resultado de uma maior vitimização das mulheres negras em decorrência do sexismo e do racismo, que precarizam seu acesso aos serviços de saúde, habitação, emprego e renda, entre outros. No grupo masculino se percebe tendência similar. Em 1993, os negros com 60 anos ou mais eram 6,5\% deste grupo, tendo passado para 7,8\% em 2006. no grupo de brancos, no mesmo período essa porcentagem varia de $8,2 \%$ para $10,6 \%$. Esta constitui, portanto, uma das mais perversas facetas das desigualdades raciais existentes em nosso país, pois as únicas justificativas para essas diferenças residem nas piores condições de vida a que negros e negras são submetidos" (IPEA, 2008, p. 3). 
necessidade íntima nós faz sempre ali e algumas coisas que a gente acha, nós guarda ali pra Subsolo [Sudesa] não levar. Acha que um cara que precisa do mato vai tocar fogo no mato?! É tipo o barraco[...] Eu preciso do barraco pra dormir e vou botar fogo nele?! Não existe isso! Do jeito que ele [o mato queimado] tá aí, nada se guarda ali pra poder alguém não ver". [Os bombeiros e moradores do prédio] nem acreditou que eu morava no Cerrado porque eu conversei tão bem no dia que eu conversei... E chegar pra ele [morador do prédio que o acusou de botar fogo no Cerrado] e dizer: 'Eu acho que o senhor é mais ignorante, parece que nunca estudou, que nunca teve numa escola pra se formar. Parece que as condições que o senhor tem foi achado no lixo. E se fosse, talvez o senhor num desprezava tanto a gente aqui como despreza"' (Entrevistado 4).

A frustração, desprezo e humilhação percebidos em suas falas acabam por serem remetidas ao Governo, que deveria zelar por eles, garantindo seus direitos de cidadania. Mas, como tais direitos só deixam de ser meras leis escritas no papel para aqueles que têm recursos financeiros e propriedades, os entrevistados sentem que estar na cidade é um ato de resistência, contra a negligência e o descaso governamental: "Olha, pra falar a verdade, pela vontade do governo eles tiravam a gente e nóis sumia para nossa cidade. Vamos dizer assim não vou entrar no cérebro dele porque não tenho esse poder, mas se tivesse tenho certeza que eu entrava. Mas pelo que penso mesmo do governo é que no fundo no fundo ele não tá nem aí para o pobre" (Entrevistado 4).

A impressão desse entrevistado parece ser partilhada por outros, que além de se sentirem abandonados pelo poder público temem sofrer alguma represália, caso manifestem abertamente sua opinião: "E, se ele [o Governo] me desse a permissão de falar sem me botar na cadeia, eu falaria. Falaria porque se você dizer na cara do governo que ele não presta, você é preso. Ele já diz logo:'Desacauto à autoridade', mas na verdade não sabe nem ele que nenhum ser humano tá tendo aquela coragem de falar a verdade. Que poucos tem essa coragem. Poucos tem essa coragem de falar a verdade e já muitos não tem" (Entrevistado 4).

Por fim, esse entrevistado revela-se completamente desiludido quanto às políticas públicas e acrescenta: "Só não é bom aqui... Acho mais difícil é a moradia, só isso aqui que eu reclamo é em termo da moradia, do governo abrir a boca dizer que 
ajuda todo mundo, mas na verdade ele mentiu numa parte" (Entrevistado 4). Tal desencanto transparece ainda em sua apreciação quanto aos benefícios destinados a distribuir renda: "Eu já me inscrevi em tantas coisas [...] Nunca ganhei nada. Daquele lado eles chegam aqui e diz: 'Ei, me dá seu nome, por favor?'. Aí eu digo: 'Pra quê vocês querem meu nome?'. Aí eles dizem: 'Rapaz, é para realmente o governo fazer algum benefício para você'. Eu digo: 'Rapaz, ó... o governo já tem meu nome várias vezes e eu não ligo. Eu creio que ele nunca pegou um papel que vocês leva pra ler. E se ele nunca pegou pra ler porque vocês todas vezes chegam pedindo meu nome?' Em Sobradinho eu dei nome, em Taguatinga eu dei nome...aqui eu dei nome. E não foi só uma vez, nem duas e nem três. Nunca adiantou" (Entrevistado 4).

Como para quem não tem acesso à informação "governo" é uma entidade absolutamente abstrata, acabam identificando no Governador a fonte de todos os males que experienciam: "O Arruda pegou o cargo do Governo, ele proibiu das pessoas de ajudar porque ele acha que muitas das pessoas que mora no barraco assim, só mora no barraco, assim, porque precisa de mantimento... Vamos dizer roupa que as pessoas passavam e davam [...] Mas não muitos [...] Eu concordo que muitos só fazem o barraco no local para conseguir as coisas. Só que a gente é diferente" (Entrevistado 4).

Mesmo com todos esses percalços os entrevistados revelam ainda um traço de otimismo, mesmo que este esteja imerso, quase afogado, em um mar de desesperança, desespero, desalento: "Eu gostei daqui, não tenho o que reclamar de Brasília não. Só reclamo mesmo do governo. Do governo eu reclamo porque ele não é totalmente humano não" (Entrevistado 4). 


\section{CONSIDERAÇÕES FINAIS}

O objetivo geral deste estudo foi compreender o processo de construção material e imaterial da cidade pela perspectiva dos marginalizados do espaço urbano, a população de rua, que não possui acesso pleno aos espaços da cidade, aos seus serviços, bens, infraestrutura. Buscou-se entender o processo de produção e os espaços negados, produzidos por essa população, mostrando que a produção espacial e a reprodução da vida são condicionadas e construídas por elementos materiais e imateriais. As construções, os edifícios, os acampamentos de plástico possuem um significado além de sua materialidade, representam sonhos, cultura, poder.

Da formulação do projeto inicial até a configuração final da monografia foram feitos recortes, alterações e acréscimos tendo alguns temas se destacado e outros sido substituídos. Entretanto, mesmo com essas alterações, o trabalho de investigação manteve-se centrado em aspectos da produção espacial na cidade, com enfoque nos espaços negados.

Desde o princípio parcial em relação aos marginalizados, geralmente migrantes de origem rural, esta monografia pretendeu evidenciar sua fala, dando voz àqueles que são continuadamente excluídos da reprodução da cidadania e, até mesmo, impossibilitados, em vários aspectos, na reprodução de sua própria vida. Sem desconsiderar os imperativos da neutralidade científica, tal perspectiva pretendeu uma análise crítica, na qual a busca de equidade tem papel fundamental.

Todo o esforço aplicado neste estudo constituiu a tentativa de estabelecer aproximações entre o material e o imaterial, o objetivo e o subjetivo. A cidade, palco das investigações do trabalho, é onde se mesclam, então, o sonhado e o sofrido, as expectativas e esperanças e a falta de oportunidades.

A compreensão além da materialidade imediatamente visível dos espaços negados na cidade exigiu a análise das representações sociais da população de rua e dos espaços que produz. Tais representações desvelaram o simbólico, o sonhado, que pode ser considerado fator que impulsiona as migrações e contribui na produção dos espaços negados. 
A representação da cidade parece envolta em uma imagem de sonhos em oposição da vida difícil experimentada nos locais de origem. Por essas lentes, a população estudada entende cidade como a condensação de todos os bens e serviços que não possuíam, antes da migração para áreas mais urbanizadas. Entretanto mesmo depois de décadas da chegada à cidade continuam a sofrer privações na reprodução da cidadania e da vida.

Mesmo sem conseguirem ter acesso aos bens e serviços que a cidade apresenta, o significado de cidade ainda guarda a esperança: é a possibilidade (mesmo que não seja real) de uma vida melhor. Tal fato é explicado nesse trabalho pela proximidade geográfica que esses migrantes encontram daquilo que almejam, o que, talvez faça parecer que estão cada vez mais próximos de concretizar seu sonho.

Considero que o presente estudo é inicial e que a caracterização dos espaços negados exige ainda trabalho mais detalhado. Certamente, outros caminhos poderão ser trilhados e outros elementos de análise poderão ser explorados. Entretanto, neste momento, foram selecionados apenas aspectos pontuais da produção dos espaços negados afim de, explicá-los tanto quanto possível aos limites de uma monografia. Portanto, trata-se de um ensaio inicial que aponta a complexidade da produção dos espaços negados, embora não se analise todos os elementos que contribuem para condição de vulnerabilidade dessas pessoas.

Apesar disso, considero que as conclusões tiradas possibilitaram ampliar o conhecimento sobre o processo de construção do imaginário sobre a cidade bem como o conhecimento sobre os espaços produzidos pela população de rua. Acredito que o maior conhecimento sobre a população de rua e seus espaços contribua para desconstruir estereótipos, ideias infundadas e falaciosas, que proliferam no preconceito e na discriminação, marcando suas vidas de maneira indelével.

Espero que as entrevistas tenham deixado claro que, ao contrário do acredita o senso comum, a população de rua não vive em tal condição por escolha, e sim porque, muitas vezes, não têm alternativa. A desmistificação que provém do real entendimento da produção desses espaços é premissa fundamental para o desenvolvimento de políticas públicas, que, efetivamente, construam ações sociais capazes de promover a cidadania daqueles que habitam os espaços negados. 
Por fim, a investigação deixou clara a importância da Geografia na análise da realidade além do visível, a compreensão dos processos e significados que perpassam a produção espacial e possibilitam entender, enxergar de fato e interpretar os processos que constituem a produção espacial. 


\section{REFERÊNCIAS}

BETTANINI, T. Espaço e ciências humanas. Tradução de Liliana Laganá Fernanses. Rio de Janeiro: Paz e Terra, v. 2, 1982.

BORTONI-RICARDO, S. M. Educação em Língua Materna - A sociolinguística na sala de aula. São Paulo: Parábola Editorial, 2004.

CARLOS, A. F. A. Uma leitura sobre a cidade. Cidades, Presidente Prudente, v. 1, número 1, 2004.

CARLOS, A. F. A. O Direito à Cidade e a Construção da Metageografia. Cidades, Presidente Prudente, v. 2, número 4, p. 221-247, 2005.

CARLOS, A. F. A. Urbanização, crise Urbana e cidade no século XXI. In: JOSÉ BORZACCHIELLO DA SILVA, L. C. L. E. E. D. (. ). Panorama da Geografia Brasileira II. 1. ed. São Paulo: Annablume, 2006. Cap. 2, p. 47-56.

CARLOS, A. F. A. A cidade. 8. ed. São Paulo: Contexto, 2007.

CAVAIGNAC, T. S. As Bastilhas Modernas: O Albergue Conviver e a Gestão da População de Rua no Distrito Federal. 1. ed. Brasília: UnB, 2009.

DI MARCO, G. Democratización de las familias - guia de recursos para talleres. Buenos Aires: UNICEF, 2005.

FRÉMONT, A. A região, espaço vivido. Coimbra: Livraria Almedina, 1980.

HALL, E. T. A linguagem Silenciosa. Tradução de Manuela Paraíso. Lisboa: Relógio D'Água Editores, 1994.

IBRAM. Instituto Brasília Ambiental. Instituto Brasília Ambiental e dos Recursos Hídricos, $2009 . \quad$ Disponivel em: <http://www.ibram.df.gov.br/005/00502001.asp?ttCD_CHAVE=12739>. Acesso em: 26 outubro 2009.

INSTITUTO ANTÔNIO HOUAISS. Dicionário Houaiss de sinônimos e antônimos. 1. ed. Rio de Janeiro: Objetiva, 2003.

IPEA. Retratos das desigualdades de gênero e raça. 3. ed. Brasília: [s.n.], 2008.

JORNAL DO SENADO. Jornal do Senado, Brasília, 16 Agosto 2004.

LEFEBVRE, H. O direito à cidade. 4. ed. São Paulo: Centauro, 1991. p. 144.

LEFEBVRE, H. O direito à cidade. Tradução de Rubens Eduardo Frias. São Paulo: Centauro, 2001.

OLIVEIRA, F. O Estado e o Urbano no Brasil. Espaço \& Debates n.6, jun-set 1982. 
PEREIRA, C. P. Rua sem saída: um estudo sobre a relação entre o Estado e a população de rua de Brasília. 1. ed. Brasília: UnB, 2008.

PORTO, D. A Moralidade da Globalização. 1. ed. Brasília: Edição do autor, 2009.

RAFFESTIN, C. Por uma geografia do poder. Tradução de Maria Cecília França. São Paulo: Ática, 1993.

RODRIGUES, J. C. O corpo na história. Rio de Janeiro: Fiocruz, 1999.

SANTOS, M. Espaço e método. São Paulo: Nobel, 1985. p. 5.

SANTOS, M. O espaço do cidadão. São Paulo: Edusp, 2007.

SCARLATO, F. C. População e Urbanização Brasileira. In: ROSS, J. L. S. Geografia do Brasil. 1. ed. São Paulo: EDUSP, 1996.

SERRES, M. Variações sobre o Corpo. São Paulo: Bertrand Brasil, 2004.

SILVA, A. C. D. As categorias como fundamentos do conhecimento geográfico. In: SILVA, A. C. D. Filosofia e Geografia. [S.I.]: [s.n.].

SJOBERG, G. Origem e Evolução das Cidades. In: DAVIS, K. E. A. Cidades, a Urbanização da Humanidade. Rio de Janeiro: Zahar, 1977.

SPOSITO, M. E. B. Capitalismo e urbanização. 15. ed. São Paulo: Contexto, 2008.

TERRACAP. Denúncia de Invasão. Terracap - Agência de Desenvolvimento do Distrito $\quad 2009 . \quad$ Dederal, em: <http://www.terracap.df.gov.br/terracapweb/formularios/denunciainvasao.php>. Acesso em: 20 Setembro 2009.

THOMAZ JÚNIOR, A. Em defesa da teoria no trabalho de campo. Caderno Prudentino de Geografia, Presidente Produente, v. 13, p. 16-27, 1991. 


\section{ANEXO A - ENTREVISTAS}

\section{Entrevista 1}

\begin{tabular}{|c|c|}
\hline Perguntas & Respostas \\
\hline Onde você nasceu? & Amargosia da Bahia. \\
\hline $\begin{array}{l}\text { É uma cidade grande, é uma } \\
\text { cidade pequena? }\end{array}$ & Conheço não. \\
\hline $\begin{array}{l}\text { Você não conhece a cidade em } \\
\text { que você nasceu? }\end{array}$ & $\begin{array}{l}\text { Nasci lá mesmo e quando eu nasci minha mãe } \\
\text { andava no mundão ai. Nasci lá e minha mãe } \\
\text { veio pra cá já. }\end{array}$ \\
\hline $\begin{array}{l}\text { Então você está aqui há muito } \\
\text { tempo? }\end{array}$ & $\begin{array}{l}\text { Sou criado aqui. Nasci lá mesmo, mas sou } \\
\text { criado aqui. }\end{array}$ \\
\hline Quantos filhos você tem? & Três. \\
\hline Quantos nasceram aqui? & Nasceram todos os três aqui. \\
\hline Quantos estão na escola? & $\begin{array}{l}\text { Um tem sete anos e está no Pernambuco com a } \\
\text { mãe. A outra tem dois anos e mora em São } \\
\text { Sebastião. E a outra nasceu agora. }\end{array}$ \\
\hline Você mora aqui? & Nesse lugar aqui? Não. \\
\hline Onde você mora? & $\begin{array}{l}\text { Brasilinha. Eu vigio o carro aí a noite e venho } \\
\text { para cá para descansar, tomar um banho aí. }\end{array}$ \\
\hline $\begin{array}{l}\text { E você estava vigiando o carro } \\
\text { até agora?(12h+-) }\end{array}$ & Não, eu vigio carro lá na quadra lá em cima. \\
\hline $\begin{array}{l}\text { Desde quando você veio para } \\
\text { Brasília em quantos lugares } \\
\text { você morou? }\end{array}$ & $\begin{array}{l}\text { Já morei Brazlândia, jardim Ingá, Sobradinho, } \\
\text { Brasilinha, Asa norte, Asa sul. }\end{array}$ \\
\hline $\begin{array}{l}\text { E qual os motivos de você se } \\
\text { mudar? O aluguel era caro, ou } \\
\text { era longe, violência, ou se } \\
\text { casou? }\end{array}$ & $\begin{array}{l}\text { Nada. Mudando assim na curtição mesmo antes } \\
\text { deu casar mesmo. Passeando pra todo lugar. } \\
\text { Agora eu pago aluguel, Né velho tenho família } \\
\text { agora. }\end{array}$ \\
\hline Mora você, sua mulher? & E minha filha. \\
\hline Quantos meses? & Vai fazer um mês \\
\hline
\end{tabular}

2. Entrevista 2 


\begin{tabular}{|c|c|}
\hline Perguntas & Respostas \\
\hline Onde você nasceu? & Belo horizonte. \\
\hline $\begin{array}{l}\text { Quanto tempo você esta em } \\
\text { Brasília? }\end{array}$ & 25 anos \\
\hline Quantos filhos você tem? & Nenhum. \\
\hline Onde você mora? & $\begin{array}{l}\text { Por enquanto estou passando aqui porque não } \\
\text { estou tendo local para morar. }\end{array}$ \\
\hline $\begin{array}{l}\text { Desde quando você veio para } \\
\text { Brasília, em quantos lugares } \\
\text { você morou? }\end{array}$ & $\begin{array}{l}\text { No gama. Morei no gama } 9 \text { anos. Depois eu vim } \\
\text { para o plano, vim para asa norte aí fiquei sem } \\
\text { apartamento e sem emprego também e vim } \\
\text { parar aqui. }\end{array}$ \\
\hline $\begin{array}{l}\text { Então você se mudou porque o } \\
\text { aluguel lá era caro? }\end{array}$ & $\begin{array}{l}\text { Não, porque o rapaz lá só tinha um apartamento } \\
\text { e ele teve que vender o apartamento. }\end{array}$ \\
\hline Por que você veio para Brasília? & Vim para estudar e trabalhar também. \\
\hline Você estudou? & Consegui tirar só o segundo grau. \\
\hline $\begin{array}{l}\text { Você veio sozinha ou veio com } \\
\text { família? }\end{array}$ & $\begin{array}{l}\text { Eu tinha família que morava no gama essa } \\
\text { época. Aí vim, saí para trabalhar em casa de } \\
\text { família, estudando e trabalhando. }\end{array}$ \\
\hline $\begin{array}{l}\text { Como você imaginava que sua } \\
\text { vida seria quando chegasse } \\
\text { aqui? }\end{array}$ & Melhor, né? Não é a vida que estou passando. \\
\hline $\begin{array}{l}\text { Você imaginava que em Brasília } \\
\text { teria uma vida melhor por quê? }\end{array}$ & $\begin{array}{l}\text { Não porque eu tinha uma tia que morava aqui e } \\
\text { lá era difícil deu estudar porque morávamos no } \\
\text { interior, entendeu? }\end{array}$ \\
\hline $\begin{array}{l}\text { Era cidade pequena? Qual } \\
\text { cidade? }\end{array}$ & $\begin{array}{l}\text { Nós morávamos em belo horizonte, mas a gente } \\
\text { tocava lavoura na roça e passava mais tempo } \\
\text { na roça. Não tinha colégio perto. }\end{array}$ \\
\hline $\begin{array}{l}\text { Você não estudava lá? } \\
\text { Começou a estudar em Brasília? }\end{array}$ & Comecei a estudar em Brasília. \\
\hline $\begin{array}{l}\text { E sua vida hoje é diferente do } \\
\text { que imaginou? }\end{array}$ & É como é terrível. Deus me livre, difícil a vida. \\
\hline $\begin{array}{l}\text { O que você achou mais } \\
\text { diferente? }\end{array}$ & $\begin{array}{l}\text { Imaginava que teria um bom emprego que a } \\
\text { vida mudaria um pouco. }\end{array}$ \\
\hline Para você o que é a cidade? & $\begin{array}{l}\text { Brasília é uma cidade assim difícil para moradia } \\
\text { que é difícil e trabalho também é difícil. }\end{array}$ \\
\hline
\end{tabular}




\begin{tabular}{|l|l|}
\hline Alguém ajuda vocês? & É muito difícil. \\
\hline
\end{tabular}

3. Entrevista 3

\begin{tabular}{|c|c|}
\hline Perguntas & Respostas \\
\hline Onde você nasceu? & Campos belos de Goiás. \\
\hline $\begin{array}{l}\text { E é uma cidade pequena? } \\
\text { Rural? }\end{array}$ & $\begin{array}{l}\text { Não é pequininha demais não, mas não é } \\
\text { grande. }\end{array}$ \\
\hline $\begin{array}{l}\text { Mas quando você nasceu era } \\
\text { uma cidade pequena? }\end{array}$ & $\begin{array}{l}\text { Era. Mas agora hoje mesmo eu sou de } \\
\text { Tocantins. Lá de Arrais. }\end{array}$ \\
\hline Você mora em Tocantins? & Eu moro aqui. \\
\hline $\begin{array}{l}\text { Quanto tempo você esta em } \\
\text { Brasília? }\end{array}$ & Eu cheguei em Brasília em Sobradinho em 71. \\
\hline Quantos filhos você tem? & Eu tinha sete, já faleceu dois. \\
\hline Morreram como? & $\begin{array}{l}\text { Matado. Tem uns } 3 \text { mês, uns } 5 \text { mês. Não tem } 5 \\
\text { mês não, não é linda (falando com a esposa) } \\
\text { que o Lucas morreu? Tem uns } 4 \text { mês. }\end{array}$ \\
\hline Mas ele era pequeno? & $\begin{array}{l}\text { Um [parte incompreensível na gravação] matou } \\
\text { ele lá no Jardim ABC. Um tiro sozinho no peito } \\
\text { esquerdo. }\end{array}$ \\
\hline Quantos anos que ele tinha? & 25. Era pai daquele menino bem ali. \\
\hline $\begin{array}{l}\text { São todos seus netos? } \\
\text { crianças) }\end{array}$ & $\begin{array}{l}\text { Não, só esse aí. Aquele outro a mãe abandonou } \\
\text { e sumiu. Sei pra onde foi não. E como ela } \\
\text { morava com meu filho, aí pra não ficar jogada, } \\
\text { aí pegamo os dois. }\end{array}$ \\
\hline E aquele outro ali? & Esse aí é minha neta também. \\
\hline Você mora aqui? & Eu fico aqui, mas realmente eu[...] \\
\hline Onde você mora? & Eu moro lá em Planaltina. \\
\hline $\begin{array}{l}\text { Por que você se mudou pra } \\
\text { Brasília? }\end{array}$ & $\begin{array}{l}\text { O hígido e problema do [parte incompreensível } \\
\text { na gravação] de calamidade que eu tinha com } \\
\text { meus filhos lá em Planaltina de Goiás. Eles } \\
\text { tavam dormindo e um tava com } 16 \text { ano. Tava } \\
\text { dormindo com uma vagabunda lá com probrema } \\
\text { de dinheiro com o filho mais velho. Foi lá duas } \\
\text { horas da manhã, a casa nossa lá é de grade, ele } \\
\text { deixou, foi assistir DVD, e deixou a grade sem } \\
\text { passar o trinco. Chegou duas horas da manhã, } \\
\text { ele tava dormindo, abriu a porta, doidão de }\end{array}$ \\
\hline
\end{tabular}




\begin{tabular}{|c|c|}
\hline & $\begin{array}{l}\text { droga, pegou, deu um tiro no, sempre meu filho } \\
\text { morre com só um tiro no peito, no peito } \\
\text { esquerdo dele. O outro tava deitado lá no } \\
\text { quarto, de } 14 \text { anos. Deu um tiro do lado nele } \\
\text { assim. }\end{array}$ \\
\hline $\begin{array}{l}\text { Mas quando você se mudou pra } \\
\text { Brasília, você tinha quantos } \\
\text { anos? }\end{array}$ & 14 anos. \\
\hline $\begin{array}{l}\text { E você, desde que chegou à } \\
\text { Brasília, morou em quantos } \\
\text { lugares? }\end{array}$ & $\begin{array}{l}\text { Em Sobradinho eu morei em vários lugar. De } \\
\text { Sobradinho eu fui pra Goiânia, aí eu fui pra } \\
\text { Planaltina de Goiás. Dois anos que eu to aqui. }\end{array}$ \\
\hline $\begin{array}{l}\text { E porque você quis vir para } \\
\text { Brasília? }\end{array}$ & É porque nós deveu lá e veio pra cá. \\
\hline Mas a vida lá era difícil? & $\begin{array}{l}\text { Lá em Brasilinha? Ih, aqui a gente faz uma } \\
\text { festa. }\end{array}$ \\
\hline Por quê? As pessoas ajudam? & Ajudam. \\
\hline E qual seu trabalho? & Eu to parado, faço 57 anos. \\
\hline Você é aposentado? & $\begin{array}{l}\text { Ainda não. Pelejei, pelejei, pelejei com o } \\
\text { negócio de... }\end{array}$ \\
\hline Aposentadoria rural? & $\begin{array}{l}\text { Não. Eu trabalhei todo bichado }[. . .] \text { to todo } \\
\text { quebrado, pernas quebrada, duas clavícula } \\
\text { quebrada. Agora mesmo eu quebrei isso aqui, } \\
\text { esse dedo. Eu tava com uma convulsão, caí (..) } \\
\text { eu tava lá no HRAN. }\end{array}$ \\
\hline $\begin{array}{l}\text { Por que você quis vir pra } \\
\text { Brasília? }\end{array}$ & $\begin{array}{l}\text { É porque me deu vontade. Eu saí do Goiás e } \\
\text { vim pra Sobradinho e de Sobradinho, ... }\end{array}$ \\
\hline E aqui ta sendo melhor? & $\begin{array}{l}\text { Do que o Goiás? Tu é louco? Lá ninguém não } \\
\text { ganha nada não. O pessoal de Planaltina do } \\
\text { Goiás fica tudo bem aqui no [...] arranjando } \\
\text { umas coisa pra levar. }\end{array}$ \\
\hline $\begin{array}{l}\text { E sua vida aqui é diferente do } \\
\text { que você imaginava do que } \\
\text { seria? }\end{array}$ & $\begin{array}{l}\text {... de vida era o Cerrado. Mas como aconteceu } \\
\text { isso eu vendi minha casa por lá. Vendi, me } \\
\text { roubaram o dinheiro. Levaram minha bolsa e os } \\
\text { documento tudo. }\end{array}$ \\
\hline $\begin{array}{l}\text { E esses meninos. Já estão na } \\
\text { escola? }\end{array}$ & $\begin{array}{l}\text { Deus me livre. A mais velha tem } 4 \text { anos. Esse } \\
\text { aqui ninguém sabe do registro. A mãe sumiu. } \\
\text { Esse menino era de uma creche lá. Ela foi lá e } \\
\text { pegou o menino escondido. A mãe dela tá no } \\
\text { meio do mundo aí. }\end{array}$ \\
\hline
\end{tabular}




\begin{tabular}{|l|l|}
\hline Para você o que é cidade? & $\begin{array}{l}\text { Ói, minha vontade aqui é morar de [parte } \\
\text { incompreensível na gravação]. Aqui é meio } \\
\text { custoso realmente. Nasagua ou Sudesa que } \\
\text { chega e leva barraco, roubam coisa de valor, } \\
\text { eles carregam tudo. Nem é pro depósito que } \\
\text { eles levaram não. Eles mesmo carregam pra } \\
\text { eles. Vem acompanhado de poliça aí, } \\
\text { entendeu? Aí ninguém pode fazer nada. Tem } \\
\text { uma negona aí que atrevidinha pra caramba. } \\
\text { Tinha um cara que é um coroão que morava lá } \\
\text { no Céu Azul, e esse homem era legal, chegava } \\
\text { com mó educação, agora essa negona [parte } \\
\text { incompreensível na gravação] só porque ela } \\
\text { vinha acompanhada de polícia, porque se fosse } \\
\text { ela sozinha ela não fazia isso com o pessoal de } \\
\text { jeito nenhum. }\end{array}$ \\
\hline E ela é policial também? & Não é nada. Bate pau do arruda. \\
\hline Ela é sua mulher? & $\begin{array}{l}\text { É. Eu sou casado com ela há 17 anos. Eu tenho } \\
7 \text { filhos com ela. Somos casados no civil. }\end{array}$ \\
\hline E quantas pessoas moram aqui? & 7 pessoas. Tudo da família. \\
\hline
\end{tabular}

4. Entrevista 4

\begin{tabular}{|l|l|}
\hline \multicolumn{1}{|c|}{ Perguntas } & \multicolumn{1}{|c|}{ Respostas } \\
\hline Onde nasceu? & No estado da Bahia. \\
\hline Era uma cidade pequena? & $\begin{array}{l}\text { Foi. Praticamente lá é... não sei nem dizer, se } \\
\text { torna mais um interiorzinho pequeno. }\end{array}$ \\
\hline Qual o nome da cidade? & Tucano \\
\hline $\begin{array}{l}\text { Há quanto tempo você está em } \\
\text { Brasília? }\end{array}$ & 8 anos. \\
\hline Por que você quis vim pra cá? & $\begin{array}{l}\text { Rapaz, eu vim pra cá pra Brasília porque é o } \\
\text { seguinte: no estado da Bahia o lado de } \\
\text { sobrevivência é difícil, é muito difícil. Vamos } \\
\text { comparar a Bahia com o Goiás. Que se torna um } \\
\text { lugar próximo de Brasília, mas na verdade é o } \\
\text { lugar que não tem como sobreviver. Se for } \\
\text { depender da cidade para sobreviver não tem } \\
\text { como. }\end{array}$ \\
\hline $\begin{array}{l}\text { Tem muita gente nessa } \\
\text { condição? }\end{array}$ & $\begin{array}{l}\text { Tem sim. Tem pessoas que moram lá que não } \\
\text { liga de vim para o DF porque está acostumado } \\
\text { com lá e tudo que faz, qualquer coisa que ganha } \\
\text { está bom. E tem gente que vive lá mesmo porque }\end{array}$ \\
\hline
\end{tabular}




\begin{tabular}{|c|c|}
\hline & $\begin{array}{l}\text { vive uma vida torta. E a vida torta hoje a gente } \\
\text { sabe que querendo ou não que a vida torta é fim } \\
\text { de carreira, mas muitos se acostumam nela e } \\
\text { ficam nela. Já que não se habitou nessa parte } \\
\text { procura melhora. }\end{array}$ \\
\hline $\begin{array}{l}\text { Quando você estava lá, como } \\
\text { imaginava que seria Brasília? }\end{array}$ & $\begin{array}{l}\text { Eu ouvi falar muito de Brasília. Dizem que as } \\
\text { pessoas diziam que Brasília era um lugar tão bom } \\
\text { não. Mas eu criei costume na minha cidade eu } \\
\text { queria uma vida melhor para não ter risco de me } \\
\text { enfiar em problemas e se torna problemas quando } \\
\text { começa a mexer no que é dos outros, problemas } \\
\text { até do cara se enfiar no que não deve, aí eu vim } \\
\text { pra Brasília. }\end{array}$ \\
\hline Você trabalhava do que lá? & $\begin{array}{l}\text { Trabalhava na roça. Plantava feijão, rançava } \\
\text { feijão, batia feijão. A diária lá era na época } 7 \\
\text { reais. }\end{array}$ \\
\hline Mas a terra não era sua? & $\begin{array}{l}\text { Não. Mesmo quando a pessoa tem bastante terra } \\
\text { pode ter até um lado mais positivo, mas não } \\
\text { tendo... }\end{array}$ \\
\hline $\begin{array}{l}\text { Você quis vim pra Brasília porque } \\
\text { era uma cidade maior? }\end{array}$ & $\begin{array}{l}\text { Porque aqui em Brasília o sistema de Brasília se } \\
\text { torna esse, logo que cheguei aqui não vim } \\
\text { achando que Brasília era do jeito que ela é. Mas } \\
\text { eu na verdade vim para Brasília pelo fato de que } \\
\text { realmente na cidade grande e desenvolvida que } \\
\text { é aqui mesmo tem como a gente sobreviver. }\end{array}$ \\
\hline Está melhor que lá? & Olha, melhor que a Bahia é. \\
\hline $\begin{array}{l}\text { Como você imaginava que ia ser } \\
\text { quando chegasse aqui? }\end{array}$ & $\begin{array}{l}\text { Brasília eu pelo fato de nunca ter visto assim } \\
\text { pessoalmente e pela televisão só algumas partes, } \\
\text { porque a parte que mostra pela televisão mostra } \\
\text { mais a parte do planalto aqueles lugares ali } \\
\text { mesmo. Só que aí eu vim pra Brasília mais } \\
\text { porque muitas pessoas disse já que aqui você } \\
\text { não se ta dando bem em Brasília tem como você } \\
\text { trabalhar,lá você pode mexer com reciclagem, lá } \\
\text { tem pessoas que ajudam e lá pode eu creio ter } \\
\text { uma vida melhor que aqui e aí eu fiz. }\end{array}$ \\
\hline Está sendo melhor aqui? & $\begin{array}{l}\text { Pra falar a verdade, não vou reclamar de Brasília } \\
\text { que se reclamar vou estar praticamente cuspindo } \\
\text { em mim próprio. Brasília é um lugar bom em } \\
\text { algumas partes é bom Só não é bom aqui acho } \\
\text { mais difícil é a moradia, só isso aqui que eu } \\
\text { reclamo e em termo da moradia, do governo abri } \\
\text { a boca dizer que ajuda todo mundo, mas na } \\
\text { verdade ele mentiu numa parte. }\end{array}$ \\
\hline
\end{tabular}




\begin{tabular}{|c|c|}
\hline Onde você mora? & $\begin{array}{l}\text { Realmente, nesse barraquinho aqui mora eu ela } \\
\text { nossos meninos. }\end{array}$ \\
\hline Você tem quantos filhos? & $\begin{array}{l}\text { Eu tenho três meninos com ela. Não que a gente } \\
\text { totalmente fique aqui fixamente. A gente Tem um } \\
\text { cantinho no Goiás só que o cantinho no Goiás } \\
\text { vamos dizer como eu comparei a Bahia a única } \\
\text { forma de sobreviver mesmo é vindo pra Brasília } \\
\text { trabalhando porque aqui antigamente as pessoas } \\
\text { ajudavam, mas só que agora que o Arruda pegou } \\
\text { o cargo do governo ele proibiu das pessoas } \\
\text { ajudar porque ele acha que muitas das pessoas } \\
\text { que mora no barraco assim só mora no barraco } \\
\text { assim porque precisa de mantimento vamos dizer } \\
\text { roupa que as pessoas passavam e davam mas } \\
\text { não muitos eu concordo que muitos só fazem o } \\
\text { barraco no local para conseguir as coisas só que } \\
\text { a gente é diferente. Esse lado mesmo de } \\
\text { trabalhar para não ficar só no barraco esperando } \\
\text { da pra ver que se torna isso aqui que é } \\
\text { reciclagem e serve mais para as pessoas que tem } \\
\text { condição porque queira ou não queira a } \\
\text { reciclagem é válida. }\end{array}$ \\
\hline $\begin{array}{l}\text { Como vocês fazem para fazer } \\
\text { reciclagem, vocês tem carroça? }\end{array}$ & $\begin{array}{l}\text { Olha eu teve um tempo atrás que eu tinha uma } \\
\text { carroça sim eu trabalhava bastante com essa } \\
\text { carroça, fazia duas viagens durante o dia para } \\
\text { não cansar o cavalo, não maltratar ele, mas o } \\
\text { Arruda mesmo levantou uma polêmica de tomar } \\
\text { carroça e cavalo. Tomaram uma carroça minha } \\
\text { que eu passei quase dois meses trabalhando } \\
\text { pagando ela, trabalhava direto para pagar ela } \\
\text { tomou minha carroça e nunca devolveu. }\end{array}$ \\
\hline $\begin{array}{l}\text { Já te tiraram daqui? Tiraram seu } \\
\text { barraco? }\end{array}$ & $\begin{array}{l}\text { Olha pra falar a verdade pela vontade do governo } \\
\text { eles tiravam a gente e nós sumia para nossa } \\
\text { cidade vamos dizer assim não vou entrar no } \\
\text { cérebro dele porque não tenho esse poder mas se } \\
\text { tivesse tenho certeza que eu entrava. Mas pelo } \\
\text { que eu penso mesmo do governo é que no fundo } \\
\text { no fundo ele não ta nem aí para o pobre. Eu } \\
\text { mesmo queria estar morando em um apartamento } \\
\text { desse ou talvez até mesmo em uma casa no chão } \\
\text { mesmo, mas que fosse aqui mesmo no DF que eu } \\
\text { pudesse trabalhar levar reciclagem para lá e } \\
\text { vender e ter a minha vida digna de cidadão, mas } \\
\text { para falar a verdade não é como a gente quer pra } \\
\text { falar mesmo a verdade... }\end{array}$ \\
\hline $\begin{array}{l}\text { Desde quando você veio para } \\
\text { Brasília em quantos lugares }\end{array}$ & Ah, morei. Morei aqui, em Sobradinho, morei em \\
\hline
\end{tabular}




\begin{tabular}{|c|c|}
\hline morou? & Taguatinga. \\
\hline $\begin{array}{l}\text { Mas em Sobradinho e Taguatinga } \\
\text { você tinha casa, residência } \\
\text { mesmo? Alugava uma casa? }\end{array}$ & Não, não. \\
\hline Por que se mudou? & $\begin{array}{l}\text { Não, o problema mais é Subsolo [Sudesa]. Eu até } \\
\text { falo um pouco errado em relação a Subsolo } \\
\text { porque não é geralmente o nome é Subsolo } \\
\text { mesmo algumas coisas eu falo certo outras não } \\
\text { porque eu não tive estudo totalmente. }\end{array}$ \\
\hline Até que série você estudou? & $\begin{array}{l}\text { Pra falar a verdade eu nunca estudei. Eu sei ler, } \\
\text { sei escrever, mas graças a pessoas que tinham } \\
\text { condições gostaram de mim e me ajudaram. }\end{array}$ \\
\hline No seu emprego? & $\begin{array}{l}\text { Não, emprego mesmo assim nunca tive não. Meu } \\
\text { emprego sempre desde que cheguei em Brasília } \\
\text { até a data de hoje vou de reciclador, quando tinha } \\
\text { carroça retirava o entulho de muitas pessoas. }\end{array}$ \\
\hline Você casou aqui ou veio casado? & $\begin{array}{l}\text { Vim sozinho. Quando cheguei aqui conheci ela } \\
\text { me juntei com ela pra . porque estava me } \\
\text { sentindo só, solitário demais ai me ajuntei com ela } \\
\text { para não ficar solitário demais. E aqui constituí } \\
\text { família e estou aqui até hoje. }\end{array}$ \\
\hline Você casou aqui ou veio casado? & $\begin{array}{l}\text { Vim sozinho. Quando cheguei aqui conheci ela } \\
\text { me juntei com ela pra . porque estava me } \\
\text { sentindo só, solitário demais ai me ajuntei com ela } \\
\text { para não ficar solitário demais. E aqui constitui } \\
\text { família e estou aqui ate hoje. }\end{array}$ \\
\hline As crianças estudam? & $\begin{array}{l}\text { Dois estudam. A menina estuda nessa escola } \\
\text { aqui, o menino na outra lá e a pequena não } \\
\text { estuda porque a creche era para colocar o dia } \\
\text { todo e para nós é ruim porque temos costume de } \\
\text { ficar com ela o dia todo. Estamos esperando ela } \\
\text { criar uma idade para ir para escola. }\end{array}$ \\
\hline $\begin{array}{l}\text { Você se arrepende de ter vindo } \\
\text { pra Brasília? }\end{array}$ & $\begin{array}{l}\text { Não me arrependo não porque aqui não preciso } \\
\text { roubar ninguém. O máximo que tem maior } \\
\text { precisão como realmente to tendo precisão } \\
\text { mesmo. A reciclagem hoje não é lá esses dinheiro } \\
\text { que as pessoas pensam. Antigamente ela era } \\
\text { valorizada, mas agora não. Um quilo de latinha já } \\
\text { cheguei a vender de } 3 \text { reais, hoje eu vendo latinha } \\
\text { de } 1 \text { real. O "cóbrio" eu já cheguei a vender de } 12 \\
\text { reais, hoje o cóbrio tá de } 4 \text {. O papelão eu cheguei } \\
\text { a vender ele de } 25 \text { centavos, hoje o papelão tá } \\
\text { de } 6 \text { centavos. E isso não é uma coisa que eu } \\
\text { próprio falo não. É uma coisa que a pessoa }\end{array}$ \\
\hline
\end{tabular}




\begin{tabular}{|c|c|}
\hline & $\begin{array}{l}\text { mesmo chega num local onde eles troca a } \\
\text { reciclagem vão ver que é assim mesmo. }\end{array}$ \\
\hline $\begin{array}{l}\text { Eles não dão valor? E é um } \\
\text { trabalho difícil, pois demora, não } \\
\text { é? }\end{array}$ & $\begin{array}{l}\text { É, a gente aqui passa uma semana trabalhando } \\
\text { pra conquistar } 50 \text { reais, } 60 \text { reais. Não chega nem } \\
\text { a } 300 \text { contos no mês. A gente não passa tão mal } \\
\text { porque a lixeira, ela ajuda a gente bastante. } \\
\text { Porque se for juntar mesmo a lixeira de Brasília } \\
\text { toda e ajuntar, vamos dizer assim, } 3 \text {, } 4 \text { pessoas } \\
\text { que são rico, que tem condições. Se brincar a } \\
\text { riqueza deles não chega à lixeira. Porque na } \\
\text { lixeira eu conquisto muitas coisas: feijão, arroz. } \\
\text { Na lixeira muitas coisas a gente conquista. Tipo } \\
\text { mesmo, carne. A gente não come carne, a gente } \\
\text { come muxiba, porque tem os açougues que as } \\
\text { pessoas dá valor a gente. Eles dão valor mesmo. } \\
\text { Eles ajudam. Não vou dizer assim a parte de } \\
\text { dinheiro, porque a parte de açougue eles não } \\
\text { tiram dinheiro pra dá. E a gente também jamais } \\
\text { chega pedindo dinheiro, porque não tem como. } \\
\text { Mas a parte assim de muxiba mesmo, como ali } \\
\text { tem um saco de muxiba que eu cheguei e pedi. É } \\
\text { uma coisa muito séria. Também tem uma parte, } \\
\text { que esse carrinho quebrou ontem. O pneu do lado } \\
\text { de cá, esse raio quebrou, a câmera de ar cortou } \\
\text { praticamente. Eu cheguei ali na oficina hoje, } \\
\text { conversei com o rapaz, aí o bicho chegou e } \\
\text { consertou e ficou certo de quando eu conseguir } \\
\text { um dinheirinho chegar lá e dar pra ele. Pelo } \\
\text { menos nessa parte ele confiou. A vida é um } \\
\text { pouco difícil, mas não me obriga aí, eu virar } \\
\text { praticamente um bandido }\end{array}$ \\
\hline $\begin{array}{l}\text { Mas você acha que a cidade é } \\
\text { muito violenta? }\end{array}$ & $\begin{array}{l}\text { Igual o estado da Bahia não. No estado da Bahia } \\
\text { cada cachorro tem um revólver. Qualquer } \\
\text { cachorro invade uma casa. Se ele sentir vontade } \\
\text { de matar uma pessoa, ele mata. A justiça lá é } \\
\text { cabulosa. Quando se fala assim, a gíria da Bahia, } \\
\text { a justiça lá é cabulosa, como também a justiça } \\
\text { daqui também, elas tem umas partes boas e } \\
\text { umas partes ruins. E lá mesmo a própria polícia } \\
\text { pode tá } 2,3 \text { carros de junto, eles desarmam o } \\
\text { bandido, manda ele "deitcha" e mata ele na frente } \\
\text { de todo mundo e não dá nada. Aqui já é um } \\
\text { pouco diferente. Eu gosto daqui, aqui nessa parte } \\
\text { da justiça é um pouco diferente. A polícia aqui não } \\
\text { mata assim, totalmente, como mata lá, como a de } \\
\text { lá mata. Aceitar a realidade. } \\
\text { Eu gostei daqui, não tenho o que reclamar de } \\
\text { Brasília não. Só reclamo mesmo do governo. Do }\end{array}$ \\
\hline
\end{tabular}




\begin{tabular}{|c|c|}
\hline & $\begin{array}{l}\text { governo eu reclamo, porque ele não é totalmente } \\
\text { ser humano não. }\end{array}$ \\
\hline $\begin{array}{l}\text { Mas você pensa um dia em voltar } \\
\text { para sua cidade? }\end{array}$ & $\begin{array}{l}\text { Não. Só vou voltar pra minha cidade se Deus } \\
\text { permitisse que eu tivesse uma boa condição de } \\
\text { chegar lá, levantar um comércio e esse comércio } \\
\text { que eu levantasse, de preferência seria um } \\
\text { comércio de comida, que é uma coisa que nunca } \\
\text { estraga e você nunca passa fome, aí seria bom } \\
\text { assim. Pra mim, o começo, tendo condição de } \\
\text { levar um comércio eu iria sim. }\end{array}$ \\
\hline Você tem família lá? & $\begin{array}{l}\text { La eu tive uma mulher e tenho um filho. Inclusive } \\
\text { eu vim pra cá pra tentar melhorar e trazer eles } \\
\text { quando, foi quando eu conheci outra família aqui } \\
\text { e ela hoje já casou com outra pessoa que ela } \\
\text { gostou e se sente bem. Meu filho tá lá nas mãos } \\
\text { dela. Primeiro Deus, segundo dela, estão bem. } \\
\text { Familiares que eu tenho, já tenho uns } 10 \text { anos } \\
\text { que eu não vejo a família. }\end{array}$ \\
\hline $\begin{array}{l}\text { Quanto tempo que você não vai } \\
\text { lá? }\end{array}$ & Tem 8 anos. \\
\hline Você veio e nunca mais voltou? & $\begin{array}{l}\text { Não. Nunca mais voltei. Liguei um tempo } \\
\text { passado, mas depois o contato que eu tinha, o } \\
\text { Subsolo quando vem leva tudo. Quando ela vem } \\
\text { a gente tem que pegar esse carrinho e sair em } \\
\text { alta velocidade e esconder ele pra que ela não } \\
\text { veja, porque se ver leva. A reciclagem, já tiveram } \\
\text { aqui duas vezes, não levaram porque eu pedi na } \\
\text { humildade. }\end{array}$ \\
\hline E eles levam até a comida? & $\begin{array}{l}\text { Levam comida, levam roupa, levam coberta, } \\
\text { colchão que a gente conquista mesmo no lixo, } \\
\text { eles levam. Uma porta dessas que a gente } \\
\text { arruma ela pra poder levar pra Brasilinha pra } \\
\text { poder quando chegar lá ter alguma utilidade eles } \\
\text { levam, e sabe que não roubamos. Sabe que o } \\
\text { que tem aqui não é roubado. Se fosse teria todo } \\
\text { "direitcho". }\end{array}$ \\
\hline $\begin{array}{l}\text { Obrigado, obrigado pelo seu } \\
\text { tempo. }\end{array}$ & $\begin{array}{l}\text { Aqui o tempo é tranquilo. E mesmo aqui é como } \\
\text { tem o ditado. Antigamente aqui sempre parava } \\
\text { carro aí dava cesta básica prá nós. Às vezes } \\
\text { como a gente tava precisando de um dinheirinho, } \\
\text { nós pedia e eles arrumavam, porque tá na cara, } \\
\text { qualquer pessoa que chegasse no local sabe } \\
\text { quando a pessoa usa droga e quando não usa. Tá } \\
\text { na cara. Tá na veste. Dá pra pessoa perceber. } \\
\text { Mas só que hoje, por causa do Arruda, não ajuda }\end{array}$ \\
\hline
\end{tabular}


mais. Alguns ainda se arriscam. Para o carro, chama e dá alguma coisa pra nós. Mas outros, sente vontade e não dá. Os que sente vontade e tem condições tem medo do Arruda. E os que não sente vontade e tem bastante condição, esses se pudessem, acho que enterrava nós também. E não fico aqui pensando, como é que vou praticamente conseguir 12 reais poder realmente pagar aquilo. Agora porque? Porque sempre sempre dá problema. Que não queria dar problema. E minha utilidade pra poder fazer peso dá problema. Só que o medo da Subsolo chegar e levar tudo. Aqui a gente trabalha com medo, veve com medo. Agora com medo mesmo, só do governo. Porque a população não. São pessoas legais. Não tem o que reclamar dos brasilienses não. Brasiliense é tantas pessoas que vem e moram aqui, e tem condição, não reclamo dele. Agora o governo, é outra coisa. [parte incompreensível na gravação] é um homem que [parte incompreensível na gravação] já foi pobre e ele me desse a permissão de eu falar sem me botar na cadeia, eu falaria. Falaria, porque se você disse na cara do governo que ele não presta, você é preso. Ele já diz logo: "Desacauto a autoridade", mas na verdade não sabe nem ele que nenhum ser humano ta tendo aquela coragem de falar a verdade. Que poucos tem essa coragem. Poucos tem essa coragem de falar a verdade e já muitos não tem. Aquele velho mesmo que desceu ali do carro ali, aquele que tá lá, ele mora ali no prédio. Deixa eu ver se é ele mesmo pra eu não me enganar. É ele mesmo. Aquele de camisa branca. Ele mora nesse prédio já tem 8 ano. Tocaram fogo nisso aí (gramado ao lado do prédio) um dias desse atrás e ele teve a cara de pau de dizer na minha cara que fui eu quem tinha tocado fogo ali, sabendo ele que é nossa necessidade íntima nós faz sempre ali e algumas coisas que a gente acha, nós guarda ali pra Subsolo não levar. Ele por ser ignorante e pelo visto nunca ter estudado na vida acha que um cara que precisa do mato vai tocar fogo no mato. É tipo o barraco. Eu preciso do barraco pra dormi e vou botar fogo nele? Eu preciso do mato pra usar ele, eu vou botar fogo nele? Não existe isso. Do jeito que ele tá aí, nada se guarda ali pra poder alguém não ver. Mas é pessoas ignorante, que eu não vou dizer nem burro, é ignorante. Ai foi quando eu falei com ele logo sério mesmo, ele 


\begin{tabular}{|c|c|}
\hline & $\begin{array}{l}\text { baixou a cabeça e saiu. Foi tanto que até os } \\
\text { bombeiros concordou comigo e disse: "não, na } \\
\text { verdade é isso mesmo" Aí saiu, foi os cara } \\
\text { mesmo. Nem acreditou que eu morava no cerrado } \\
\text { porque eu conversei tão bem no dia que eu } \\
\text { conversei. E chegar pra ele e dizer: "Eu acho que } \\
\text { o senhor é mais ignorante, parece que nunca } \\
\text { estudou, que nunca teve numa escola pra se } \\
\text { formar. Parece que as condições que o senhor } \\
\text { tem foi achado no lixo. E se fosse, talvez o senhor } \\
\text { num desprezava tanto a gente aqui como } \\
\text { despreza". Mas as pessoas chegam, acusam, } \\
\text { fala. "Ah, você não vale nada, num sei o que lá..." } \\
\text { já outros dizem: "Não, pelo menos você trabalha, } \\
\text { num fica só esperando, esperando" e ai vai. Fazer } \\
\text { o que, né? E não fico triste com Brasília. Não com } \\
\text { sobrevivência não. Eu só fico triste com a } \\
\text { moradia. Durante esse tempo todo que eu to aqui, } \\
\text { o governo nunca me deu uma cesta básica. }\end{array}$ \\
\hline $\begin{array}{l}\text { E os programas que o governo } \\
\text { oferece, como bolsa família. Você } \\
\text { nunca tentou se inscrever? }\end{array}$ & $\begin{array}{l}\text { Eu já me inscrevi em tantas coisas. Nunca ganhei } \\
\text { nada. Daquele lado eles chegam aqui e diz: "Ei, } \\
\text { me de seu nome aí por favor" Aí eu digo: "Pra que } \\
\text { vocês querem meu nome?". Aí eles dizem: } \\
\text { "Rapaz, é pra poder realmente o governo fazer } \\
\text { algum benefício pra você". Eu digo: "Rapaz, ó. O } \\
\text { governo já tem meu nome várias vezes e eu não } \\
\text { ligo". Eu creio que ele nunca pegou um papel que } \\
\text { vocês leva pra ler. E se ele nunca pegou pra ler } \\
\text { onde é que vocês todas vezes chegam pedindo } \\
\text { meu nome não." Em Sobradinho eu dei nome, em } \\
\text { Taguatinga eu dei nome. Aqui eu dei nome. E não } \\
\text { fui só uma vez, nem duas nem três. Nunca } \\
\text { adiantou. E tenho minha preocupação mesmo } \\
\text { assim. Eu mesmo agora, quem diria que alguém } \\
\text { pelo menos parasse o carro e dissesse: "Ói, tem } \\
\text { um quintal lá em casa pra capinar. Vamos lá } \\
\text { capinar." Eu iria. "Tem um caminhão ali pra } \\
\text { descarregar" eu iria. E mesmo sem ter condição } \\
\text { de carregar tanto peso, como eu tenho uma } \\
\text { cirurgia aqui que é do pé da barriga ao estomago. }\end{array}$ \\
\hline Você fez cirurgia por quê? & $\begin{array}{l}\text { Essa cirurgia é um tiro que eu levei em } \\
\text { Taguatinga. Uma discussão por besteira que eu } \\
\text { nem ameacei o cara nem nada. E ele [parte } \\
\text { incompreensível na gravação] pagou um de } \\
\text { menor pra vir é tirar minha vida. Ele me atirou no } \\
\text { abdômen, do lado esquerdo que atingiu quatro } \\
\text { órgãos. Atingiu quatro órgãos, o estômago, atingiu } \\
\text { o fígado, o rim e o baço. E sempre, sempre eu } \\
\text { vivo adoentado. Também não recramo, mas na }\end{array}$ \\
\hline
\end{tabular}




\begin{tabular}{|l|l|}
\hline verdade mesmo Brasília é bom. Eu acho legal \\
aqui. Não fico triste com essa cidade não. Minha \\
tristeza aqui mesmo é só o governo. A minha \\
preocupação mesmo agora no momento abaixo \\
da moradia é mais só esse negócio desse pneu aí \\
que com certeza que Deus vai me ajudar. Que \\
com reciclagem o caminhão só vem buscar \\
quando tem bastante. Só que a gente tem medo \\
de trabalhar e perder. Aí vai na rua e da uma \\
trabalhada
\end{tabular}

5. Entrevista 5

\begin{tabular}{|c|c|}
\hline Perguntas & Respostas \\
\hline Onde você nasceu? & Pernambuco. \\
\hline Era cidade pequena? & Não, era a cidade mais grande. \\
\hline Faz quanto tempo que está aqui? & Nem lembro mais, tanto tempo. \\
\hline Você veio para cá moça? & Não, já vim mãe de família já. \\
\hline Quantos filhos você teve aqui? & Cinco. morreu um. \\
\hline $\begin{array}{l}\text { Cinco que nasceram aqui em } \\
\text { Brasília? Você já tinha filho } \\
\text { quando veio? }\end{array}$ & $\begin{array}{l}\text { Cinco nasceram aqui, mas já tinha filho quando } \\
\text { eu vim. }\end{array}$ \\
\hline $\begin{array}{llll}\text { Quantos } & \text { dos } & \text { seus } & \text { filhos } \\
\text { estudam? } & & & \\
\end{array}$ & $\begin{array}{l}\text { [parte incompreensível na gravação] } \\
\text { quiseram estudar mais. }\end{array}$ \\
\hline Onde você mora? & Na invasão do iate. \\
\hline $\begin{array}{l}\text { Em quantos lugares morou aqui } \\
\text { em Brasília? }\end{array}$ & [parte incompreensível na gravação] \\
\hline Você se mudou várias vezes? & Não se mudei não. \\
\hline $\begin{array}{l}\text { Por que veio para Brasília, achou } \\
\text { que a vida seria melhor? }\end{array}$ & $\begin{array}{l}\text { Achei que ia ser melhor, achei que ia melhorar foi } \\
\text { a piorar. Fiquei viúva, meus filhos morreu então } \\
\text { decidi vim pra cá. }\end{array}$ \\
\hline $\begin{array}{l}\text { O que falavam de Brasília quando } \\
\text { você estava lá? }\end{array}$ & Falavam que aqui era bom tudo. \\
\hline Você trabalha como recicladora? & É. \\
\hline Você tem carroça? & Não a gente cata latinha. \\
\hline $\begin{array}{l}\text { E desde que chegou aqui sempre } \\
\text { trabalhou de recicladora? }\end{array}$ & É, justo. \\
\hline
\end{tabular}




\begin{tabular}{|l|l|}
\hline $\begin{array}{l}\text { Por que foi diferente do que você } \\
\text { imaginou aqui? }\end{array}$ & $\begin{array}{l}\text { Imaginei que aqui era bom e dava pra fazer as } \\
\text { coisas mais fáceis. }\end{array}$ \\
\hline Arrependeu-se de ter vindo? & $\begin{array}{l}\text { Não me arrependi não porque vim pra ficar meus } \\
\text { filhos. }\end{array}$ \\
\hline Pensa em voltar para lá? & $\begin{array}{l}\text { Penso em voltar para lá ainda mas se meus filhos } \\
\text { vem mais eu porque estão tudo casado. }\end{array}$ \\
\hline Tem família lá? & $\begin{array}{l}\text { Tenho, assim tenho tios, mas família mesmo veio } \\
\text { tudo mais eu. }\end{array}$ \\
\hline Para você o que é cidade? & Tudo,tudo. \\
\hline
\end{tabular}

6. Entrevista 6

\begin{tabular}{|c|c|}
\hline Perguntas & Respostas \\
\hline Onde você nasceu? & Pernambuco. \\
\hline Era um cidade pequena? & A mesma da dela (referindo-se a entrevistada 5). \\
\hline Há quanto tempo você ta aqui? & 29 anos. \\
\hline E ela? & Ela tem uma faixa de uns 18 anos. \\
\hline Você mora aqui? & $\begin{array}{l}\text { Não, morei muitos anos aqui, } 29 \text { anos aqui aí } \\
\text { quando foi o... Tem o que? Faz } 5 \text { anos que mudei } \\
\text { daqui para Brasilinha. Porque meu sogro me deu } \\
\text { uma casa lá pra mim morar, morar não passar } \\
\text { uma temporada porque aqui não é lugar de gente } \\
\text { não véi depois que meus filhos cresceram viraram } \\
\text { rapaz e moça precisam de coisa melhor, né? De } \\
\text { estudo, aqui é muito difícil. }\end{array}$ \\
\hline Você tem quantos filhos? & Quatro. \\
\hline Qual a idade deles? & O mais velho tem 15 anos, ta assistindo aí dentro. \\
\hline E eles estudam? & Graças a Deus. \\
\hline $\begin{array}{l}\text { Vocês participam de algum } \\
\text { programa tipo bolsa família? }\end{array}$ & $\begin{array}{l}\text { Não porque não tenho documento. Daqui a } 15 \\
\text { dias a juíza vai levar meu processo de volta para } \\
\text { o gabinete do fórum de Brasília pra ver o que vai } \\
\text { acontecer comigo porque nem eu nem eles temos } \\
\text { documento, aí estamos aí na luta. }\end{array}$ \\
\hline Você perdeu o documento? & $\begin{array}{l}\text { Não antes deu me amigar, ajuntar com o filho dela } \\
\text { aqui eu nunca vivia com meu documento aí no dia } \\
\text { que me amiguei e minha mãe ficou revoltada } \\
\text { comigo ela resolveu me devolver aí quando eu fui } \\
\text { no cartório daqui do conjunto nacional que fui tirar }\end{array}$ \\
\hline
\end{tabular}




\begin{tabular}{|c|c|}
\hline & $\begin{array}{l}\text { a identidade e o resto dos documentos não servia } \\
\text { mais pra nada aí perdeu e até esqueci meu nome } \\
\text { todo e aí vai. }\end{array}$ \\
\hline $\begin{array}{l}\text { Em quantos lugares você morou } \\
\text { desde quando chegou à Brasília? }\end{array}$ & $\begin{array}{l}\text { Aqui em Brasília eu morei no SIA, morei no } 28 \text { no } \\
\text { setor de embaixadas, morei no cruzeiro, na } \\
\text { invasão do cruzeiro, mas a temporada melhor } \\
\text { mesmo foi aqui. }\end{array}$ \\
\hline $\begin{array}{l}\text { Por que se mudou desses } \\
\text { lugares? }\end{array}$ & $\begin{array}{l}\text { É porque nós chegou aqui e procurava um canto } \\
\text { melhor aí passávamos um ano, um ano e meio } \\
\text { em um canto via que não tava dando certo ia nós } \\
\text { saía e ia pra outro, aí fumo e o último foi esse } \\
\text { aqui pra ficar mesmo, foi ótimo. }\end{array}$ \\
\hline $\begin{array}{l}\text { Mesmo tendo conseguido a casa } \\
\text { lá você vem aqui por quê? }\end{array}$ & $\begin{array}{l}\text { Não tipo assim, Né?! nas férias meus filhos } \\
\text { entraram de recesso } 15 \text { dias aí to aqui, mas } \\
\text { segunda feira eu vou-me embora porque minha } \\
\text { mãe mora aqui, ela tem uma casa lá, mas é } \\
\text { alugada mas ela vevi mais aqui do que lá. Minha } \\
\text { família todinha vevi aqui. Tem uma que mora na } \\
\text { vila planalto que é, ela é o que dona Zefinha? Dos } \\
\text { comperado ela é presidente, né?! Pois é, tem uma } \\
\text { que mora na Vila duas, três que mora no } \\
\text { Valparaíso e já tem uma que vevi em Brasilinha e } \\
\text { assim vai indo. }\end{array}$ \\
\hline Seus filhos estudam onde? & $\begin{array}{l}\text { Meus meninos?! Tudo é lá em Brasilinha. É } \\
\text { porque foram pra vila, pegaram dinheiro e foram } \\
\text { cortar o cabelo, comprar sandália aí eu deixei eles } \\
\text { irem hoje. É desse jeito a vida. }\end{array}$ \\
\hline Por que você veio para Brasília? & $\begin{array}{l}\text { Menino, eu vim pra cá porque lá a nossa situação } \\
\text { é muito difícil e aqui tá um pouco difícil, mas nem } \\
\text { tanto, porque vem um filho de Deus e ajuda com } \\
\text { alguma coisa, aí vem outro. }\end{array}$ \\
\hline Aqui é melhor do que lá? & É, aqui é melhor do que lá. Com certeza. \\
\hline Você pensa em voltar? & Nunca. Nunca. \\
\hline Você tinha uma casa lá? & $\begin{array}{l}\text { Minha mãe tinha, mas nem que ela tivesse umas } \\
\text { mil casa lá, nunca que voltava lá. }\end{array}$ \\
\hline $\begin{array}{l}\text { Como você imaginava que sua } \\
\text { vida ia ser quando você chegasse } \\
\text { aqui? }\end{array}$ & $\begin{array}{l}\text { Bom filha, tipo assim, uma aventura igual ta sendo } \\
\text { essa aventura pra nós, né, que nós aqui dorme de } \\
\text { madrugada, os meninos brincam até meia noite } \\
\text { aí, amanhece o dia matando rato e por aí se vai. } \\
\text { Pra ele é o que? Uma aventura, né. E pra nós } \\
\text { também. }\end{array}$ \\
\hline
\end{tabular}




\begin{tabular}{|c|c|}
\hline $\begin{array}{l}\text { E sua vida hoje como é? Muito } \\
\text { diferente do que você imaginou? }\end{array}$ & $\begin{array}{l}\text { Não, é assim, sabe, é um pouco, nem tanto, é um } \\
\text { pouco, porque uma que a coisa que eu queria era } \\
\text { o estudo dos meus filhos, graças a Deus eu } \\
\text { consegui. Estão estudando, tão tendo educação. }\end{array}$ \\
\hline E lá, não tinha como não? & $\begin{array}{l}\text { Lá no Pernambuco jamais, minha filha. Lá a } \\
\text { situação é tão difícil. Aqui eles já estão tudo } \\
\text { crescido, já estão moça, rapaz, essas coisa. E } \\
\text { aqui, sei lá, é um servicinho, o serviço é mais leve } \\
\text { pra eles, sabe? }\end{array}$ \\
\hline $\begin{array}{l}\text { E você veio com filho pra cá ou } \\
\text { eles nasceram aqui? }\end{array}$ & $\begin{array}{l}\text { Quando eu cheguei aqui, meu filho, eu tinha o } \\
\text { que? Eu tinha de } 8 \text { a } 9 \text { anos. Eu tenho } 33 \text { aí... e aí } \\
\text { tamo aí guerriando com o mundo, o mundo } \\
\text { guerriando com nós, mas aqui é melhor }\end{array}$ \\
\hline E para você, o que é a cidade? & $\begin{array}{l}\text { É tudo, com eu acabei de falar. É tudo, né? } \\
\text { Porque todo mundo precisa de luz, precisa de } \\
\text { água, precisa de paz, precisa de trabalho e tudo, } \\
\text { né? De respeito, honestidade. Pra mim é tudo. }\end{array}$ \\
\hline $\begin{array}{l}\text { Você acha que a cidade da isso } \\
\text { pra todo mundo? }\end{array}$ & $\begin{array}{l}\text { Dá! Dá pra todo mundo. Mas tem muita gente que } \\
\text { não quer, né minha filha. Mas que dá, dá. Mas } \\
\text { tem gente que não sabe aproveitar. Mas tem } \\
\text { gente que fica preferindo ficar bebendo pinga do } \\
\text { que tá trabalhando. Tem gente que preferiu ficar } \\
\text { matando e roubando do que trabalhando, do que } \\
\text { estudando. Porque aqui em Brasília tem muita } \\
\text { gente que ajuda na educação em tudo, mas tem } \\
\text { muita gente que não quer e fica na gandaia. }\end{array}$ \\
\hline $\begin{array}{l}\text { Quando você chegou à Brasília } \\
\text { você foi estudar? }\end{array}$ & $\begin{array}{l}\text { Minha filha, eu comecei estudar lá no } \\
\text { Pernambuco. Eu não tirei nem a primeira serie aí } \\
\text { eu sai. Até hoje nunca que estudei. }\end{array}$ \\
\hline Por que você não quis estudar? & $\begin{array}{l}\text { Porque é coisa de criança, gostava mais da } \\
\text { bagunça e hoje olho para os meus filhos e me } \\
\text { arrependo porque eu não estudei. Porque minha } \\
\text { mãe me botou no colégio, mas eu me arrependo } \\
\text { muito porque eu não estudei. Porque estudo } \\
\text { minha filha, em pensar, minha filha, no tempo que } \\
\text { nóis tá é o estudo. Tem tempo que eu até passo } \\
\text { fome naquela Brasilinha velha, mas eu digo, num } \\
\text { vou pra lá não. Num vou não, porque o tempo que } \\
\text { eu to lá meus filhos estão perdendo escola. Aí eu } \\
\text { não venho, fico lá. }\end{array}$ \\
\hline $\begin{array}{llr}\text { E você } & \text { sempre, desde } & \text { que } \\
\text { chegou aqui, trabalhou de }\end{array}$ & Sempre. \\
\hline
\end{tabular}




\begin{tabular}{|l|l|}
\hline recicladora? & \\
\hline Você procurou outro emprego? & $\begin{array}{l}\text { Mas como é que procura se nós aveve sem } \\
\text { documento. Mas quando eu começar a ganhar o } \\
\text { bolsa escola eu não vou vir para aqui mais não. } \\
\text { Vou não, porque eu não ganho nada do governo, } \\
\text { sabe porque não tenho documento, mas quando } \\
\text { começar eu não venho não. }\end{array}$ \\
\hline
\end{tabular}

7. Entrevista 7

\begin{tabular}{|c|c|}
\hline Perguntas & Respostas \\
\hline Onde você nasceu? & Na Paraíba \\
\hline $\begin{array}{l}\text { Era uma cidade pequena? Qual } \\
\text { o nome da cidade? }\end{array}$ & É. Olho d'água? \\
\hline $\begin{array}{l}\text { Há quanto tempo você está em } \\
\text { Brasília? }\end{array}$ & 23 anos. \\
\hline Você se casou aqui? & Não. Deus me livre. Casei na minha terra. \\
\hline Você já veio casada com filho? & Já. Tudo. Não tem nenhum daqui não. \\
\hline São quantos filhos? & 9. Eram 9, mas Deus levou dois. \\
\hline Eles morreram como? Criança? & $\begin{array}{l}\text { Não. Morreu com 36, e o outro com 29. Só } \\
\text { tenho só dois filhos agora. Mulher eu tenho } 5 .\end{array}$ \\
\hline $\begin{array}{l}\text { Você mora aqui? Onde é que } \\
\text { você mora? }\end{array}$ & $\begin{array}{l}\text { Não, eu não moro aqui não. Eu só trabalho. Eu } \\
\text { pago aluguel. }\end{array}$ \\
\hline Em Brasilinha? & Tu já ta sabendo. \\
\hline $\begin{array}{l}\text { É que todo mundo aqui, parece } \\
\text { que mora em Brasilinha. Desde } \\
\text { quando você veio pra Brasília } \\
\text { em quantos lugares você morou } \\
\text { por aqui? Muitos? }\end{array}$ & $\begin{array}{l}\text { Ó minha filha, eu morei em vários cantos. Santa } \\
\text { Maria, Valparaíso. }\end{array}$ \\
\hline $\begin{array}{l}\text { E por que você se mudou? O } \\
\text { aluguel era caro? Por que era } \\
\text { longe? Por causa da violência? }\end{array}$ & $\begin{array}{l}\text { Não, porque meu menino não gosta do } \\
\text { Valparaíso. A gente veio pra Recanto das Emas } \\
\text { daí [parte incompreensível na gravação], daí eu } \\
\text { gente veio pra Brasilinha. Mas eu to com } \\
\text { vontade de ir pra São Sebastião. }\end{array}$ \\
\hline Brasilinha é aonde mesmo? & $\begin{array}{l}\text { É Goiás. Perto de Planaltina. Lá perto do Vale } \\
\text { do Amanhecer. }\end{array}$ \\
\hline Por que você veio pra Brasília? & $\begin{array}{l}\text { Porque eu quis! Meu menino me trouxe. Eles } \\
\text { era pedreiro, trabalhavam em obra e foi me }\end{array}$ \\
\hline
\end{tabular}




\begin{tabular}{|c|c|}
\hline & buscar. \\
\hline $\begin{array}{l}\text { Eles vieram antes da senhora, } \\
\text { então? }\end{array}$ & $\begin{array}{l}\text { Foi. Depois foram me buscar. Os dois que } \\
\text { faleceu. um tinha } 36 \text { e o outro } 29 \text {. }\end{array}$ \\
\hline $\begin{array}{l}\text { E como você imaginava que sua } \\
\text { vida seria aqui? }\end{array}$ & $\begin{array}{l}\text { Meu filho trabalhava aqui, trabalhava em São } \\
\text { Bernardo dos Campos, e [parte incompreensível } \\
\text { na gravação] }\end{array}$ \\
\hline $\begin{array}{l}\text { Você prefere aqui? Você } \\
\text { trabalhava com o quê lá? }\end{array}$ & $\begin{array}{l}\text { Prefiro. Lá no nordeste? Trabalhava na } \\
\text { chibanca, trabalhava no açude. }\end{array}$ \\
\hline Na roça? & $\bar{E}$ É. \\
\hline Pensa em voltar para lá? & $\begin{array}{l}\text { Penso, mas só quando eu me aposentar, já fiz } \\
60 \text { anos. Minha menina mora no Valparaiso. } \\
\text { Aqui a Sula que era pra ela arranjar meus } \\
\text { documentos para [parte incompreensível na } \\
\text { gravação]. } \\
\text { Puxar minha aposentadoria aí se eu me } \\
\text { aposentar vou-me embora que não aguento } \\
\text { mais não que aqui só tem ladrão véi, só tem } \\
\text { ladrão! }\end{array}$ \\
\hline Então lá é melhor que aqui? & $\begin{array}{l}\text { É, pelos umas partes é porque pelo menos o } \\
\text { cara trabalha e tem as coisas aqui trabalha e o } \\
\text { ladrão vai levando. Semana mesmo roubaram a } \\
\text { casa da minha filha em Brasilinha, não sobrou } \\
\text { nada. }\end{array}$ \\
\hline $\begin{array}{l}\text { O que você acha de diferente da } \\
\text { sua cidade para a cidade? }\end{array}$ & $\begin{array}{l}\text { Tem muita diferença porque aqui é muito } \\
\text { diferente do Nordeste. Porque antigamente } \\
\text { quando eu era gente podia trabalhar, pegar em } \\
\text { cabo de chibanca, de foice roçado de tudo e } \\
\text { hoje não posso. Já to veia, tenho braço doente, } \\
\text { mas se eu me aposentar eu vou embora véi. }\end{array}$ \\
\hline $\begin{array}{l}\text { Por que não tenta } \quad \text { a } \\
\text { aposentadoria rural? }\end{array}$ & $\begin{array}{l}\text { Minha menina vai correr atrás, a caçula. Ela } \\
\text { mora lá no Valparaíso. Ela mandou um recado } \\
\text { que era pra mim ir pra lá, faz tempo que não } \\
\text { tem, mas daqui para semana eu vou lá e } \\
\text { quando me aposentar vou-me embora dessa } \\
\text { miséria aqui. Não pode ter nada aqui, nem um } \\
\text { rádio velho. Ladrão passa a perna mesmo. }\end{array}$ \\
\hline $\begin{array}{l}\text { Eles vêm de fora ou daqui } \\
\text { mesmo? }\end{array}$ & $\begin{array}{l}\text { Daqui mesmo, do nordeste vieram aqui só pra } \\
\text { roubar, trabalhar ninguém quer trabalhar não. } \\
\text { Agora roubá é com eles mesmo. Já falei, vou } \\
\text { dar uma facada em um qualquer hora. Nunca } \\
\text { visitei a porta cadeia não, mas tem hora... nem } \\
\text { sei que diabo é a cadeia, mas não perdi a fé de }\end{array}$ \\
\hline
\end{tabular}


meter a faca em num vou para cadeia mesmo. Não tô nem aí desgraça não trabalha vevi só robando.

8. Entrevista 8

\begin{tabular}{|c|c|}
\hline Perguntas & Respostas \\
\hline Onde você nasceu? & Paraíba. \\
\hline Quanto tempo esta aqui? & 23 anos. \\
\hline Onde você mora? & To alugando no Valparaíso. \\
\hline $\begin{array}{l}\text { Desde quando chegou aqui, em } \\
\text { quantos lugares você morou? }\end{array}$ & Aqui, La no cruzeiro, iate. \\
\hline Por que se mudou? & $\begin{array}{l}\text { Porque era longe e outros foi em Valparaíso foi } \\
\text { porque botaram fogo na minha moradia e nos } \\
\text { meus documentos. }\end{array}$ \\
\hline Quantos filhos você tem? & Tenho 7, mas comigo vevi só 4. \\
\hline Os outros moram com quem? & $\begin{array}{l}\text { Um não fala comigo, mora com o pai que eu } \\
\text { larguei, pois o juiz pegou pequenininhos. }\end{array}$ \\
\hline Pegou como? & $\begin{array}{l}\text { Pegou daqui porque aqui só pode ficar de maior. } \\
\text { Menor não pode não. }\end{array}$ \\
\hline Quantos nasceram aqui? & $\begin{array}{l}\text { Tudinho. Só tenho um que é baiano, tá lá } \\
\text { embaixo. }\end{array}$ \\
\hline $\begin{array}{l}\text { É o seu filho mais velho? Você } \\
\text { chegou a morar na Bahia? }\end{array}$ & $\begin{array}{l}\text { Não, é o encostado com o mais velho que é } \\
\text { baiano. Eu ia pra lá com a minha sogra viver } \\
\text { com o filho dela lá, mas depois separou. }\end{array}$ \\
\hline $\begin{array}{l}\text { A cidade que você morava na } \\
\text { Paraíba era pequena? }\end{array}$ & $\begin{array}{l}\text { Não, lá é grande. Mas eu saí de lá pequena, } \\
\text { minha mãe que me trouxe. }\end{array}$ \\
\hline Qual a cidade? & Vaporanga. \\
\hline $\begin{array}{l}\text { Você imaginava que sua vida } \\
\text { em Brasília seria diferente que } \\
\text { era hoje? }\end{array}$ & $\begin{array}{l}\text { Foi. É pior quando roubaram meus meninos } \\
\text { porque lá não tem esse negócio de tomá os } \\
\text { filhos dos outros. Eles ajudam, não toma. }\end{array}$ \\
\hline Você nem sabe mais deles? & $\begin{array}{l}\text { Não, eu vou visitar eles todo domingo, amanhã } \\
\text { eu vou. Fica aí na casa de [parte } \\
\text { incompreensível na gravação], na W3 Norte }\end{array}$ \\
\hline $\begin{array}{l}\text { Se você soubesse que sua vida } \\
\text { ia ser assim, você preferia ter } \\
\text { ficado lá? }\end{array}$ & Não tive escolha, eu era criança. \\
\hline
\end{tabular}




\begin{tabular}{|l|l|}
\hline Você pensa em voltar pra lá? & $\begin{array}{l}\text { Até penso porque eles não tomam o filho dos } \\
\text { outros, eles ajudam. }\end{array}$ \\
\hline $\begin{array}{l}\text { E pra você, o que tem na cidade } \\
\text { que vale a pena morar aqui? }\end{array}$ & $\begin{array}{l}\text { Tem que canto que não me aluga não mode os } \\
\text { menino. Eu achei um canto em Valparaíso e a } \\
\text { mulher falou que não ia me alugar porque eu } \\
\text { tinha muitos meninos. Difícil arrumar um canto } \\
\text { pra mim e pros meus meninos. Só querem } \\
\text { alugar pra casal sem filho }\end{array}$ \\
\hline
\end{tabular}

9. Entrevista 9

\begin{tabular}{|c|c|}
\hline Perguntas & Respostas \\
\hline Onde você nasceu? & Remanso, Bahia. \\
\hline Era uma cidade pequena? & $\begin{array}{l}\text { Nem pequena e nem grande, mas menor que } \\
\text { Brasília, eu acho. }\end{array}$ \\
\hline Você trabalhava de que lá? & Na roça. \\
\hline Você veio pra Brasília quando? & $\begin{array}{l}\text { Faz muitos anos, cheguei em Brasília em 86, } 22 \\
\text { anos. }\end{array}$ \\
\hline $\begin{array}{l}\text { Desde quando você veio para } \\
\text { Brasília, em quantos lugares } \\
\text { morou aqui? }\end{array}$ & $\begin{array}{l}\text { Morei no SIA, Guará, Bandeirante, moro na Vila } \\
\text { planalto, minha esposa é presidente da } \\
\text { cooperativa ACOPLAN. Pode entrar no site que } \\
\text { você vê o nome dela lá. }\end{array}$ \\
\hline $\begin{array}{l}\text { Você se mudou desses lugares } \\
\text { por quê? }\end{array}$ & $\begin{array}{l}\text { Porque naquele tempo, é assim invasão, é } \\
\text { assim a gente sai de uma invasão e vai para } \\
\text { outra e vai para outra porque não tem lugar pra } \\
\text { gente ficar. Cruzeiro, morei no Cruzeiro atrás da } \\
\text { Ceasa ali na Parmalat. }\end{array}$ \\
\hline $\begin{array}{l}\text { Tiram muito invasão, já ouvi falar } \\
\text { que levam tudo até comida. }\end{array}$ & $\begin{array}{l}\text { Levam, levam. Essa semana levaram tudo, } \\
\text { colchão da minha sogra, tudo. }\end{array}$ \\
\hline Por que você veio para Brasília? & $\begin{array}{l}\text { Quando eu vim para Brasília, foi por causa de } \\
\text { uma irmã minha. Ela saiu fora de casa, se } \\
\text { perdeu e meu pai veio atrás dela e eu vim com } \\
\text { ele e depois que vim com ele não voltei mais } \\
\text { para Bahia. }\end{array}$ \\
\hline Pensa em voltar? & Não gosto mais da Bahia. \\
\hline Acha que aqui é melhor? & $\begin{array}{l}\text { Oh, muito bom. Brasília o pais melhor que a } \\
\text { gente tem no nosso país é Brasília. Tudo é mais } \\
\text { fácil. }\end{array}$ \\
\hline O que você acha mais fácil & $\begin{array}{l}\text { Dinheiro. Ela mesmo é paraibana. Pergunta pra } \\
\text { ela se lá no nordeste dela é bom, não é bom. } \mathrm{O}\end{array}$ \\
\hline
\end{tabular}




\begin{tabular}{|c|c|}
\hline aqui? & custo de vida é mais fácil. \\
\hline Quantos filhos você tem? & 7. \\
\hline $\begin{array}{l}\text { Eles estudam? Nasceram aqui } \\
\text { ou lá? }\end{array}$ & $\begin{array}{l}\text { Moram tudo comigo, só a mais velha que } \\
\text { nasceu na Bahia. }\end{array}$ \\
\hline Você casou aqui? & $\begin{array}{l}\text { Achei ela aqui em Brasília e ela é da Paraíba, é } \\
\text { irmã dela [entrevista 8] }\end{array}$ \\
\hline $\begin{array}{l}\text { Aqui é diferente do que você } \\
\text { imaginou? O que você esperava } \\
\text { encontrar aqui? }\end{array}$ & $\begin{array}{l}\text { Não imaginava nada. Eu acho que só quis sair } \\
\text { de lá. }\end{array}$ \\
\hline Achava lá ruim? & $\begin{array}{l}\text { A Bahia não é ruim, é mais difícil. A Bahia é um } \\
\text { estado muito bom a Bahia, mas difícil é o custo } \\
\text { de vida. Mas é mais gostoso que aqui, mais } \\
\text { gostoso porque lá no nordeste é muito bom. Só } \\
\text { ruim o custo de vida que é mais difícil. }\end{array}$ \\
\hline Trabalhava na roça? & $\begin{array}{l}\text { Na roça, minha mãe tem roça essas coisas tudo, } \\
\text { mas a gente trabalha na roça da pessoa [parte } \\
\text { incompreensível na gravação]. Aqui o olha meu } \\
\text { carrinho, é meu carrinho esse aqui sabe quanto } \\
\text { eu ganho? Máximo em } 15 \text { dias? } 300 \text { conto, na } \\
\text { Bahia ganho } 100,50 \text { reais o máximo o custo de } \\
\text { vida é difícil, mas igual eu tava te falando é mais } \\
\text { gostoso porque a gente tem o privilegio de mais } \\
\text { melhor, pode dormir, deixar suas crianças andar } \\
\text { a vontade que ninguém mexe e aqui não. }\end{array}$ \\
\hline Acha aqui muito violento? & É, mais ou menos. \\
\hline Mais violento que lá? & $\begin{array}{l}\text { Mas lá na Bahia tem cangaceiro muito ruim se } \\
\text { falar vou Ihe matar agora, eles matam. Lá na } \\
\text { Bahia é muito perigoso, do outro tipo de } \\
\text { criminais é muito perigoso. }\end{array}$ \\
\hline $\begin{array}{l}\text { O que tem aqui de diferença } \\
\text { com a roça? }\end{array}$ & $\begin{array}{l}\text { Tudo porque lá não tem roça, não tem nada, } \\
\text { mas lá é melhor a rocinha. Assim, a coisa mais } \\
\text { linda do mundo na beira do são Francisco, mas } \\
\text { as coisas são mais difíceis um pouco. }\end{array}$ \\
\hline
\end{tabular}

10. Entrevista 10

\begin{tabular}{|l|l|}
\hline \multicolumn{1}{|c|}{ Perguntas } & \multicolumn{1}{c|}{ Respostas } \\
\hline Onde você nasceu? & Paraíba. \\
\hline $\begin{array}{l}\text { Há quanto tempo você esta em } \\
\text { Brasília? }\end{array}$ & 30 anos. \\
\hline
\end{tabular}




\begin{tabular}{|c|c|}
\hline Onde você mora? & Brasilinha. \\
\hline $\begin{array}{l}\text { Desde quando você veio pra } \\
\text { Brasília, em quantos lugares } \\
\text { você morou? }\end{array}$ & $\begin{array}{l}\text { Morei no Guará, Bandeirante... } \\
\text { [Entrevista 9]: - nos mesmos lugares que eu } \\
\text { morei porque quando eu vim pra Brasília foi logo } \\
\text { quando eu conheci ele. Rodamos Brasília toda, } \\
\text { Guará, Cruzeiro, Bandeirantes. }\end{array}$ \\
\hline $\begin{array}{l}\text { E você mudou desses lugares } \\
\text { porque você achava que era } \\
\text { violento, aluguel era caro? }\end{array}$ & $\begin{array}{l}\text { Porque lá onde nós tava morando não tinha } \\
\text { trabalho e eu já estou com } 80 \text { anos já. }\end{array}$ \\
\hline $\begin{array}{l}\text { Você está há quanto tempo em } \\
\text { Brasilinha? }\end{array}$ & Já há mais que um mês. \\
\hline Você tem quantos filhos? & $\begin{array}{l}\text { Eu tenho nove. Mas dois morreu e os outros } \\
\text { estão tudo vivos, mas já estão todos grandes. }\end{array}$ \\
\hline Como eles morreram? & No hospital. \\
\hline $\begin{array}{l}\text { Por que você veio para Brasília? } \\
\text { Você morava em uma cidade } \\
\text { pequena? }\end{array}$ & $\begin{array}{l}\text { Porque lá onde eu morava o lugar é muito } \\
\text { devagar, não tem trabalho, aí tive que correr, } \\
\text { correr. E daqui é capaz que eu vou voltar para } \\
\text { trás. }\end{array}$ \\
\hline $\begin{array}{l}\text { E aqui esta sendo melhor do } \\
\text { que lá? }\end{array}$ & $\begin{array}{l}\text { Não, não, veja. Aqui [parte incompreensível na } \\
\text { gravação] é melhor Marília. Entendeu. Mas lá é } \\
\text { muito difícil menina, difícil. }\end{array}$ \\
\hline Você não pensa em voltar não? & Eu penso sim. \\
\hline $\begin{array}{l}\text { Você esta aqui mais pelo } \\
\text { trabalho mesmo, mas se } \\
\text { pudesse voltar você voltava? }\end{array}$ & É. \\
\hline $\begin{array}{l}\text { Aqui é muito diferente do que } \\
\text { você imaginou? }\end{array}$ & $\begin{array}{l}\text { [choro] quero voltar pra lá, não quero ficar aqui. } \\
\text { Fica lá do que aqui. Lá minha Irmã cuida de } \\
\text { mim. Obrigada, eu gostei eu gostei. }\end{array}$ \\
\hline
\end{tabular}

\section{Entrevista 11}

\begin{tabular}{|l|l|}
\hline \multicolumn{1}{|c|}{ Perguntas } & \multicolumn{1}{c|}{ Respostas } \\
\hline Onde você nasceu? & Bahia \\
\hline Era uma cidade pequena? & Pequena. \\
\hline Você trabalhava na roça? & Trabalhava na roça, você acertou. \\
\hline Veio pra cá faz quanto tempo? & Três meses e pouco. \\
\hline
\end{tabular}




\begin{tabular}{|c|c|}
\hline Onde você mora aqui? & Por enquanto estou na ruera, no trechão aqui. \\
\hline $\begin{array}{l}\text { Então você só morou aqui desde } \\
\text { quando chegou? }\end{array}$ & É. \\
\hline Porque você veio pra Brasília? & $\begin{array}{l}\text { Para procurar a melhora e esta melhorando } \\
\text { devagarzinho. Mesmo no sofrimento. }\end{array}$ \\
\hline $\begin{array}{l}\text { Mas você está achando que } \\
\text { está melhorando? }\end{array}$ & tá. \\
\hline $\begin{array}{l}\text { Como você imaginava que seria } \\
\text { sua vida aqui? }\end{array}$ & $\begin{array}{l}\text { Um pouco melhor, mas tá...devagar } \\
\text { devagarinho vai melhorando. }\end{array}$ \\
\hline $\begin{array}{l}\text { É muito diferente do que você } \\
\text { imaginou? }\end{array}$ & $\begin{array}{l}\text { É muito diferente. Mesma coisa de quando fui } \\
\text { para São Paulo. Achava que era uma coisa } \\
\text { diferente. Cheguei lá, sofre pra caralho, voltei } \\
\text { pra Bahia e agora tô aqui. }\end{array}$ \\
\hline $\begin{array}{l}\text { Por que é diferente do que você } \\
\text { imaginou? }\end{array}$ & $\begin{array}{l}\text { Assim, é financeiro. O cara pensa que é uma } \\
\text { coisa e se torna mais difícil. }\end{array}$ \\
\hline Quantos filhos você tem? & Três. \\
\hline Eles estão aqui? & $\begin{array}{l}\text { Não, os três estão na Bahia. Aliás tem dois na } \\
\text { Bahia e um em Goiânia. }\end{array}$ \\
\hline $\begin{array}{l}\text { Para você, o que tem na cidade } \\
\text { que a difere da roça? }\end{array}$ & Aí isso é muita coisa. \\
\hline $\begin{array}{l}\text { Por que você quis vir para } \\
\text { cidade? O que te motiva? }\end{array}$ & $\begin{array}{l}\text { É o seguinte, tenho três profissões boas. Tô } \\
\text { aqui porque tô meio desleixado, não por causa } \\
\text { dos outros, mas por causa de mim mesmo que } \\
\text { eu to bebendo muita bira aí. Eu tenho três } \\
\text { profissões: sou padeiro, pintor de casa. To } \\
\text { arrumando o documento aí que eu perdi o } \\
\text { documento. Tá melhorando, vou comprar lote, a } \\
\text { mulher não, mas meus filhos vou começar a } \\
\text { ajudar. Eu sempre mando troco. Hoje mesmo } \\
\text { ganhei um trocado fazendo uns buracos ai. Vou } \\
\text { mandar } 100 \text { conto pra eles. To trabalhando. }\end{array}$ \\
\hline
\end{tabular}

12. Entrevista 12

\begin{tabular}{|l|l|}
\hline \multicolumn{1}{|c|}{ Perguntas } & \multicolumn{1}{c|}{ Respostas } \\
\hline Era uma cidade pequena? & A cidade era pequena, mas agora já ta grande. \\
\hline Qual é a cidade? & Barra do Corsa. \\
\hline Você trabalhava de que lá? & Eu trabalhava de roça lá. \\
\hline
\end{tabular}




\begin{tabular}{|c|c|}
\hline $\begin{array}{l}\text { Há quanto tempo você está em } \\
\text { Brasília? }\end{array}$ & Uns 16 anos. \\
\hline Onde você mora? & Arapongas. \\
\hline Onde é? & Planaltina. \\
\hline $\begin{array}{l}\text { Desde quando você veio para } \\
\text { Brasília, em quantos lugares } \\
\text { você morou? }\end{array}$ & 5 lugares. \\
\hline Quais os motivos de se mudar? & $\begin{array}{l}\text { Tem nada a ver não, só porque vai mudando de } \\
\text { um lugar para outro, normal. Violência não tem } \\
\text { como se esconder esta em todos os lugares. }\end{array}$ \\
\hline Por que você veio para Brasília? & Tentar uma vida melhor. \\
\hline $\begin{array}{l}\text { Por que achou que aqui seria } \\
\text { melhor? }\end{array}$ & Dinheiro, achei que ia ganhar um dinheirinho. \\
\hline Como imaginava? & $\begin{array}{l}\text { Imaginava que ia ganhar muito dinheiro, mas } \\
\text { não tá sendo assim não. Tá difícil, tá bravo. }\end{array}$ \\
\hline Como está sendo? & Tá dando para viver mais ou menos mas.... \\
\hline Você se arrepende de ter vindo? & Não. \\
\hline O que tem aqui de diferente? & $\begin{array}{l}\text { Tanta coisa, aqui eu não trabalho pra ninguém } \\
\text { não. Trabalho por minha conta, sou pescador. } \\
\text { Lá eu pescava, mas não dava pra ganhar o } \\
\text { dinheiro que ganho aqui não. }\end{array}$ \\
\hline Onde você pesca? & Em minas, aqui, em todo lugar. \\
\hline Quantos filhos você não tem? & Aqui comigo dois, mas tenho quatro. \\
\hline Onde estão os outros dois. & $\begin{array}{l}\text { Um no Piauí e outro no Maranhão, mas } \\
\text { nasceram aqui depois que foram embora. }\end{array}$ \\
\hline
\end{tabular}

\section{Entrevista 14}

\begin{tabular}{|l|l|}
\hline \multicolumn{1}{|c|}{ Perguntas } & \multicolumn{1}{c|}{ Respostas } \\
\hline Onde você nasceu? & Eu nasci no Ceará. \\
\hline Era uma cidade pequena? & Sim. \\
\hline Você trabalhava de que lá? & $\begin{array}{l}\text { Eu trabalhava de roça lá. Eu saí de lá com 29 } \\
\text { anos. Aí vim pro Goiás e aqui tô há 17 anos } \\
\text { para 18 anos. }\end{array}$ \\
\hline
\end{tabular}




\begin{tabular}{|c|c|}
\hline Onde você mora? & $\begin{array}{l}\text { Atualmente estou aqui. Mas eu trabalhava em } \\
\text { uma fazenda, agora estou vendo os documentos } \\
\text { para me aposentar. Só esperando o CPF } \\
\text { chegar. }\end{array}$ \\
\hline O que você fazia na fazenda? & Trabalho braçal, mexendo com gado, lavoura. \\
\hline Você tem filho? & Tenho, mas todos no norte. \\
\hline $\begin{array}{l}\text { Qual cidade que você morava } \\
\text { lá? }\end{array}$ & Pires ferreira. \\
\hline $\begin{array}{l}\text { Desde quando você veio para } \\
\text { Brasília, morou em vários } \\
\text { lugares? Mudou-se muito? }\end{array}$ & $\begin{array}{l}\text { Morei em Padre Bernardo, Brasilinha. Agora no } \\
\text { distrito morei em várias cidades. }\end{array}$ \\
\hline Por que está aqui agora? & Porque estou mexendo com documento. \\
\hline Você se mudou por quê? & $\begin{array}{l}\text { Não, porque eu trabalhava em construção civil e } \\
\text { quando o aluguel era mais barato e era mais } \\
\text { calmo eu morava. Morei na Ceilândia, } \\
\text { Taguatinga, Planaltina e foi nesses três lugares } \\
\text { que eu morei. }\end{array}$ \\
\hline Por que você veio para Brasília? & $\begin{array}{l}\text { Porque isso é ilusão mesmo, isso é o mundo. } \\
\text { Porque da minha família, só eu vivo no mundo. } \\
\text { Os outros vivem tudo em casa, ninguém sai. } \\
\text { Meus irmãos moram todos unidos, nunca } \\
\text { nenhum precisou sair de casa, mas o mundo é } \\
\text { isso mesmo. }\end{array}$ \\
\hline $\begin{array}{l}\text { Achava que sua vida seria } \\
\text { diferente? }\end{array}$ & $\begin{array}{l}\text { Não achava não. É negócio de problema de } \\
\text { família, me separei da mulher em } 1973 / 74 \text {. Aí } \\
\text { vim para o Goiás aqui e fiquei aqui, aí fiquei } \\
\text { aqui. Passei muitos anos sem ter comunicação } \\
\text { com a minha família, passei } 17 \text { anos sem ter } \\
\text { comunicação com ninguém. Agora um ano e } \\
\text { meio pra cá que eu entrei em contato com a } \\
\text { minha família direto. Entro em contato com eles } \\
\text { direto, quase toda semana eu ligo. Mas eu vou } \\
\text { embora. }\end{array}$ \\
\hline Vai voltar? & $\begin{array}{l}\text { Vou, vou voltar. Só ajeitar as coisas e vou } \\
\text { embora para o Ceará. }\end{array}$ \\
\hline Você prefere lá? & $\begin{array}{l}\text { É que lá eu tenho minhas coisas, minha família, } \\
\text { tenho alguma coisinha lá. Se não fosse por } \\
\text { conta dos netos... Tenho neto. Tem gente que } \\
\text { nem conheço. Mas é tudo problema da vida, } \\
\text { tudo faz parte da vida. Logo nesse tempo } \\
\text { tomava muita cachaça, aí em } 2001 \text { eu parei de } \\
\text { tomar cachaça. Faz } 9 \text { anos e me deu bem, }\end{array}$ \\
\hline
\end{tabular}




\begin{tabular}{|l|l|}
\hline & $\begin{array}{l}\text { tenho amigo, aí trabalho em qualquer lugar. Se } \\
\text { sair agora na região que eu trabalho tenho } \\
\text { trabalho. Qualquer hora que chegar lá e falar } \\
\text { que quero trabalhar eu consigo. }\end{array}$ \\
\hline Você se casou aqui em Brasília? & $\begin{array}{l}\text { Me juntei com várias mulheres, mas não casei } \\
\text { não. }\end{array}$ \\
\hline
\end{tabular}

14. Entrevista 15

\begin{tabular}{|c|c|}
\hline Perguntas & Respostas \\
\hline Onde você nasceu? & Eu nasci em Caicó, no Rio Grande do Norte. \\
\hline É cidade pequena? & $\begin{array}{l}\text { Não, é grande. É uma das quinta cidade do } \\
\text { estado. }\end{array}$ \\
\hline $\begin{array}{l}\text { Faz quanto tempo que você veio } \\
\text { para Brasília? }\end{array}$ & $\begin{array}{l}\text { Eu cheguei aqui em } 72.22 \text { de fevereiro de } \\
\text { 1972, lá na praça do relógio. }\end{array}$ \\
\hline $\begin{array}{l}\text { E por que você veio para } \\
\text { Brasília? }\end{array}$ & $\begin{array}{l}\text { Eu vim pelo seguinte: eu saí do rio grande do } \\
\text { norte com } 12 \text { anos e } 10 \text { mês. O motivo mesmo } \\
\text { é que eu tinha vontade. }\end{array}$ \\
\hline Mas você veio com sua família? & $\begin{array}{l}\text { Não. Eu vim acompanhado de uma família. Aí } \\
\text { eu pedi meus documentos de menor que era o } \\
\text { atestado de saúde, o atestado de vacina, o } \\
\text { atestado de escolaridade, carteira profissional } \\
\text { de menor. Eu adulei minha mãe e ela foi lá e } \\
\text { tirou, aí me encaminharam com uma família. } \\
\text { Meu pai era muito amigo do homem que me } \\
\text { trouxe, Deus bote ele no céu. Aí autorizou, aí eu } \\
\text { vim pra Santa Helena de Goiás. Em Santa } \\
\text { Helena de Goiás eu fiquei na fazenda } \\
\text { Paulope[?], finado Paulope[?], na fazenda Água } \\
\text { Limpa, e depois eu fugi da fazenda e fui } \\
\text { trabalhar na usina. Aí da usina, eu saí da usina } \\
\text { e fui trabalhar no armazém de uma firma lá, } \\
\text { construtora Vila Rica S/A, tava construindo uns } \\
\text { armazém em Assis brasem[?] e eu fui trabalhar } \\
\text { lá. Eu morava num hotel e a firma pagava um } \\
\text { hotel pra gente. Um dia eu encontrei um } \\
\text { catarinense lá, eletricista, aí fomos pra Brasília, } \\
\text { eu com ele e um cearense - "vamos para } \\
\text { Brasília?" - Não quero ficar a toa em Brasília } \\
\text { não, daí ficamos na casa de um sargento lá. } \\
\text { "Bora!" Daí nós viemos. Daí aqui, } 2 \text { de fevereiro, } \\
\text { era umas 20:40 quando eu cheguei na vila } \\
\text { Praça do relógio. Só que é de frente assim de } \\
\text { um terminal de uma empresa de Goiânia, [parte } \\
\text { incompreensível na gravação]. Daí quando foi }\end{array}$ \\
\hline
\end{tabular}




\begin{tabular}{|c|c|}
\hline & $\begin{array}{l}\text { no dia seguinte nos apresentamos na fila, na } \\
\text { segunda-feira. Aí continuou. Aí fui ter família. }\end{array}$ \\
\hline Teve filho aqui? & Tenho, tenho bastante. \\
\hline Quantos filhos? & $\begin{array}{l}\text { Eu tenho 6. Tenho } 5 \text { aqui, } 2 \text { moram em Santo } \\
\text { Antônio do Descoberto, uma mora em } \\
\text { Taguatinga, outro mora no cabo da barragem e } \\
\text { tenho outro que mora em Uberlândia. } \\
\text { Etibira [?]. Primeiro eu fui noivo com ela, daí ela } \\
\text { ficou grávida, aí foi embora e me deixou aí na } \\
\text { solidão. }\end{array}$ \\
\hline E você mora aonde? & $\begin{array}{l}\text { Eu moro aqui. Eu moro em Santa Maria, mas só } \\
\text { que eu não tenho moradia porque eu me } \\
\text { separei de uma mulher recentemente. Aí } \\
\text { peguei, pra não ficar lá vendo a cara dela e ela } \\
\text { a minha, é melhor a gente marcar distância. E } \\
\text { pra ficar evitando ser vítima de piada, essas } \\
\text { coisas, inclusive tive na justiça esses tempos } \\
\text { agora, } 3 \text { meses atrás , mas fui liberado da } \\
\text { justiça. Ela me deu dois tapas na cara e eu dois } \\
\text { na cara dela e a gente caiu na justiça, aí fomos } \\
\text { para o tribunal. Chegando lá, ela não foi a } \\
\text { audiência, eu fui. Falei com a juíza, parecendo a } \\
\text { senhora assim [referindo-se à Marília], pedi para } \\
\text { ela: - "gostaria de pedir um coisa para a } \\
\text { senhora: me de uma carta, como que eu não } \\
\text { devo nada a justiça, como que eu não tem } \\
\text { problema nenhuma com a justiça." Daí ela } \\
\text { disse: - "Te dou a carta mas com uma condição: } \\
\text { mantém } 600 \text { metros da casa dela". Aí eu estou } \\
\text { com a carta aqui, qualquer coisa que os homens } \\
\text { chegar e querer falar alguma coisa, tá aqui, } \\
\text { quem me deu foi uma juíza e um promotor. Aí } \\
\text { eu to aqui. Eu trabalho de pedreiro, só que } \\
\text { agora eu tô por aqui e vou vigiar carro ali na } 315 \\
\text { com a } 16 \text { ali. Aí fico lá até a padaria fechar, a } \\
\text { padaria fecha } 10 \text { horas, } 10 \text { e pouco. Aí eu } \\
\text { desço. Minha cama é aquela ali, uns papelões, } \\
\text { plástico e um edredon. }\end{array}$ \\
\hline $\begin{array}{l}\text { E você achava que a vida ia ser } \\
\text { diferente em Brasília? }\end{array}$ & $\begin{array}{l}\text { Eu achava não, foi diferente. O negócio porque, } \\
\text { me desculpa a palavra, quem me estragou } \\
\text { muito foi cabaré, mulherzada e baralho, }\end{array}$ \\
\hline
\end{tabular}




\begin{tabular}{|c|c|}
\hline & $\begin{array}{l}\text { desculpa a palavra. Foi isso que me estragou. } \\
\text { Já possuí lote, casa. Foi pro beleléu. Uma eu } \\
\text { perdi pra mulher, o outro veio [parte } \\
\text { incompreensível na gravação]. O ano passado } \\
\text { eu passei } 6 \text { meses lá e agora eu estou } \\
\text { querendo ir, pra ir de uma vez. }\end{array}$ \\
\hline Voltar pra sua cidade? & $\begin{array}{l}\text { É, voltar pra lá. Já estou com } 51 \text { anos de idade } \\
\text { e lá as coisas são melhores, tem a minha mãe, } \\
\text { aí, to indo, uma madame outro dia falou que vai } \\
\text { me dar a passagem. Aí eu vou conversar com } \\
\text { ela hoje, pra ver se ela me dá um tempo pra eu } \\
\text { ir. Vou pegar o telefone dela, pra quando for } \\
\text { dezembro, eu vou passar o natal com minha } \\
\text { mãe. Tô com } 51 \text { anos de idade e nunca mais } \\
\text { passei um natal ou semana santa com minha } \\
\text { mãe. Agora mesmo lá tem as festas de Nossa } \\
\text { senhora de Santana, a padroeira da cidade, } \\
\text { uma santa muito poderosa. Começou dia } 17 \text { e } \\
\text { termina dia } 29 \text { o feriado. Aí eu quero ver se eu } \\
\text { vou pra ficar por lá, porque lá eu não tenho } \\
\text { habilitação, mas lá eu posso dirigir táxi, lavar } \\
\text { carro. Lavo carro, eu sei lavar carro muito bem. } \\
\text { Em frente a um hotel lá, a praça de automóveis, } \\
\text { a praça de táxi lá. É perto da minha mãe. Ela vai } \\
\text { fazer } 73 \text { anos agora, não sei se é dia 15, por aí, } \\
\text { no mês de agosto agora ela faz } 73 \text { anos. Meus } \\
\text { filhos moram aí, tem um neto. }\end{array}$ \\
\hline $\begin{array}{l}\text { Seus filhos moram todos aqui? } \\
\text { Nasceram aqui? }\end{array}$ & $\begin{array}{l}\text { Todos aqui. Nasceu Valéria, o Ariel. Fabiana e } \\
\text { Daniel nasceu em Santo Antônio do } \\
\text { Descoberto. Ariel nasceu em Ceilândia, Valéria } \\
\text { no hospital de Taguatinga, Ariana foi em } \\
\text { Taguatinga. Daniel e Fabiana nasceu em Santo } \\
\text { Antônio mesmo. Bom, parteira lá que tratou. } 2 \text { é } \\
\text { do Goiás e } 3 \text { é do distrito e um que morreu } \\
\text { também era do distrito. }\end{array}$ \\
\hline Ele morreu como? & $\begin{array}{l}\text { Recém nascido. Quando veio naquela época, } \\
78 \text {, os táxis eram fuscas velhos, Brasília, essas } \\
\text { coisa aí. Quando vem na } 23 \text {, na subida do eixo } \\
\text { pra Taguatinga, perto do posto de gasolina, a } \\
\text { mulher já tinha estourado a bolsa e saído a } \\
\text { cabeça e a cabeça dele bateu no acolchoado do } \\
\text { banco do carro. Aí viveu, parece, } 2 \text { minutos, } \\
\text { recém nascido. Foi enterrado lá em Taguatinga. } \\
\text { E continua a vida, NE? Aí a gente faz que nem } \\
\text { a música do bicho lá, deixa a vida me levar, né? }\end{array}$ \\
\hline
\end{tabular}


15. Entrevista 18

\begin{tabular}{|l|l|}
\hline \multicolumn{1}{|c|}{ Perguntas } & \multicolumn{1}{|c|}{ Respostas } \\
\hline Onde você nasceu? & $\begin{array}{l}\text { Nasci na Bahia, [parte incompreensível na } \\
\text { gravação], município do estado da Bahia. }\end{array}$ \\
\hline $\begin{array}{l}\text { É uma cidade pequena? Era } \\
\text { rural lá? }\end{array}$ & Cidade pequena, rural lá. \\
\hline Você fazia o que lá? & Trabalhava na roça. \\
\hline Onde você mora? & $\begin{array}{l}\text { Eu moro na rua. Morava em [parte } \\
\text { incompreensível na gravação] derrubaram a } \\
\text { invasão lá. Tô morando na rua agora. }\end{array}$ \\
\hline $\begin{array}{l}\text { Desde quando você veio para } \\
\text { Brasília, você morou em vários } \\
\text { lugares aqui? }\end{array}$ & $\begin{array}{l}\text { Não, quando eu vim para Brasília foi em 72. Aí } \\
\text { daqui eu fui para são Paulo e de São Paulo, } \\
\text { Mato Grosso. }\end{array}$ \\
\hline $\begin{array}{l}\text { Por que você quis vir para } \\
\text { cidade? }\end{array}$ & Em procura de tratamento e trabalho. \\
\hline Médico? & Porque lá nem medico não tinha. \\
\hline $\begin{array}{l}\text { Como você imaginava que seria } \\
\text { sua vida na cidade? }\end{array}$ & Melhor. \\
\hline Não foi melhor que imaginou? & Não, foi pior ainda. \\
\hline $\begin{array}{l}\text { Você pensa em voltar para sua } \\
\text { cidade? }\end{array}$ & $\begin{array}{l}\text { Não. Depois de muito tempo aí eu nem pensei } \\
\text { em voltar pra minha terra mais. }\end{array}$ \\
\hline Quantos filhos você tem? & Não tenho filho não. \\
\hline
\end{tabular}

